Maurer School of Law: Indiana University

Digital Repository@ Maurer Law

Indiana Law Journal

Volume 89 | Issue 1

Article 10

Winter 2014

\title{
FRAND's Forever: Standards, Patent Transfers, and Licensing Commitments
}

Jay P. Kesan

University of Illinois at Urbana-Champaign, kesan@illinois.edu

Carol M. Hayes

University of Illinois at Urbana-Champaign, carol.mullins@gmail.com

Follow this and additional works at: https://www.repository.law.indiana.edu/ilj

Part of the Communications Law Commons, and the Intellectual Property Law Commons

\section{Recommended Citation}

Kesan, Jay P. and Hayes, Carol M. (2014) "FRAND's Forever: Standards, Patent Transfers, and Licensing Commitments," Indiana Law Journal: Vol. 89 : Iss. 1 , Article 10.

Available at: https://www.repository.law.indiana.edu/ilj/vol89/iss1/10

This Article is brought to you for free and open access by the Law School Journals at Digital Repository @ Maurer Law. It has been accepted for inclusion in Indiana Law Journal by an authorized editor of Digital Repository @ Maurer Law. For more information, please contact rvaughan@indiana.edu.

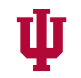

JEROME HALL LAW LIBRARY

INDIANA UNIVERSITY

Maurer School of Law
Blooming ton 


\title{
FRAND's Forever: Standards, Patent Transfers, and Licensing Commitments
}

\author{
JAY P. KESAN $^{*}$ AND CAROL M. HAYES ${ }^{* *}$
}

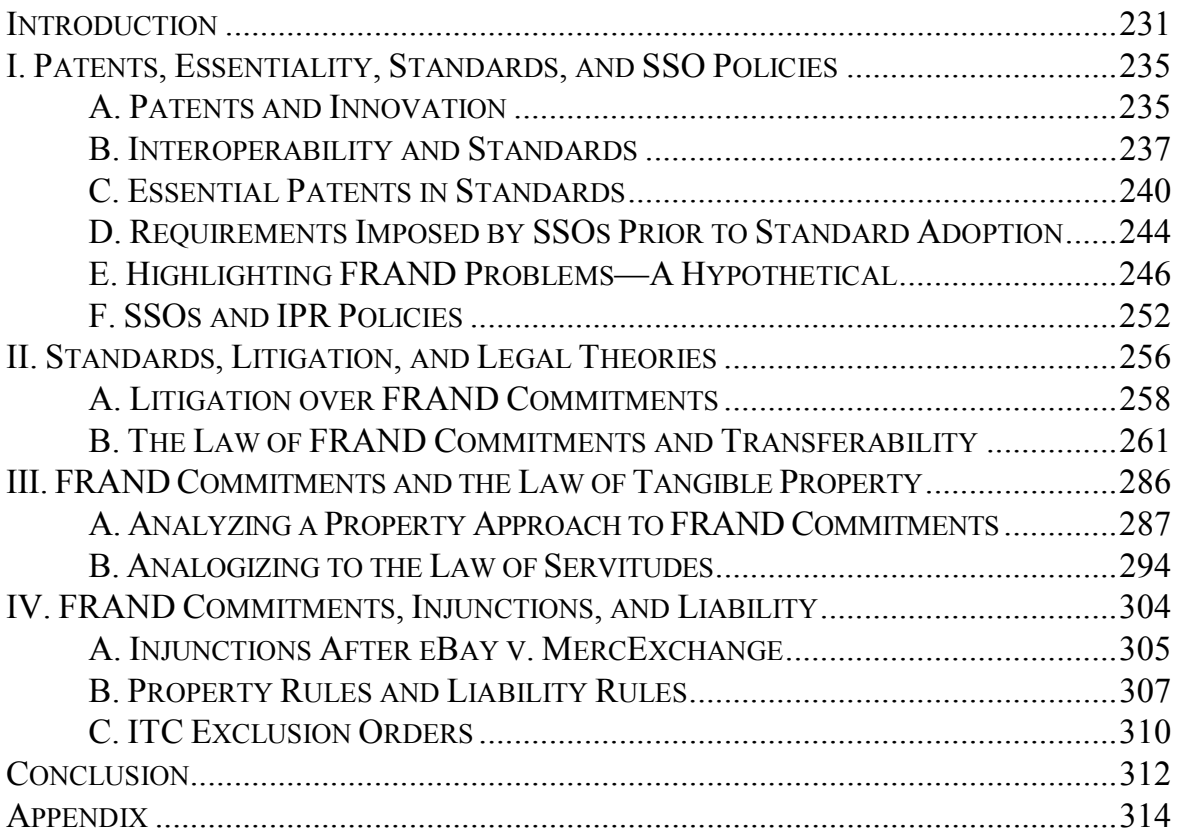

\section{INTRODUCTION}

Not all wars involve heavy munitions. Some wars are fought with court filings. The smartphone patent wars are being fought to see who will dominate an increasingly valuable market. According to a study by Nielsen in the summer of 2012 , over $55 \%$ of mobile subscribers in the United States own smartphones. ${ }^{1}$ And the demographic that is acquiring smartphones keeps getting younger. Nielsen further

$\dagger$ Copyright (C) 2014 Jay P. Kesan and Carol M. Hayes.

* Professor and H. Ross \& Helen Workman Research Scholar, University of Illinois College of Law.

** Research Associate, University of Illinois College of Law; Fall 2010 Fellow in the Christine Mirzayan Science and Technology Policy Graduate Fellowship Program at the National Academy of Sciences.

The authors wish to thank the Board on Science, Technology, and Economic Policy (STEP) of the National Academies for their support of this work. The authors acknowledge the valuable guidance and useful discussions provided by Sandy Block, Jorge Contreras, John Golden, Paul Heald, Tim Holbrook, Jon Law, Robert Lawless, Mark Lemley, Peter Maggs, Amy Marasco, Steve Merrill, Adam Mossoff, Gil Ohana, Scott K. Peterson, David Schwartz, Claudia Tapia Garcia, and Verity Winship.

1. Young Adults and Teens Lead Growth Among Smartphone Owners, NIELSEN NEwSWIRE (Sept. 10, 2012), http://www.nielsen.com/us/en/newswire/2012/young-adults -and-teens-lead-growth-among-smartphone-owners.html. 
indicates that $74 \%$ of young adults between twenty-five and thirty-four years old own a smartphone, and $58 \%$ of American teenagers between the ages of thirteen and seventeen own a smartphone. ${ }^{2}$ This is a battle for profits, but more than that, this is a battle for long-term customers who are starting to use sophisticated technologies at younger and younger ages.

But the current patent war is also broader than smartphones. The year 2012 saw a number of new developments in patent litigation over smartphones and related technologies. This includes disputes over the 802.11 wireless standards, or $\mathrm{Wi}-\mathrm{Fi}^{3}{ }^{3}$ without which many smartphones would just be phones and many modern homes would have CAT 5 cables snaking from room to room to allow gaming consoles, laptops, and other devices to share the same network connection. These are not patents on technologies that only a small subset of the population uses. These patents involve everyday technologies that many of us take for granted, from smartphones to video game consoles to streaming videos.

Patent litigation in this area has been making headlines, in part because some of these cases are between two parties that are already household names. In August 2012, Apple successfully obtained a jury award against Samsung in excess of $\$ 1$ billion, but the court subsequently reduced the damages award by over $\$ 450$ million. ${ }^{4}$ In November 2012, Nokia began filing in courts around the world to enforce a Swedish arbitration decision declaring that Research In Motion, the maker of Blackberry smartphones, must reach a new licensing agreement with Nokia for wireless technology patents or else stop selling Blackberry products that use Wi-Fi. ${ }^{5}$ In May 2012, a German court granted Motorola's request for an injunction against Microsoft over the latter's use of patented technologies relating to the H.264 video encoding standard and the 802.11 wireless standard ${ }^{6}$ - but in the United States in September 2012, the Ninth Circuit ruled that the injunction was not self-enforcing. ${ }^{7}$ And these are just three examples of disputes between large companies that actually practice the patents in issue. A discussion of patent assertion entities (PAE), ${ }^{8}$ which

2. Id.

3. Univ. of Miami Leonard M. Miller Sch. of Med., Wi-Fi/802.11 Standards, MiAMI.EDU, http://it.med.miami.edu/x275.xml.

4. Apple, Inc. v. Samsung Elecs. Co., No. 11-CV-01846-LHK, 2013 WL 772525, at *1, *16 (N.D. Cal. Mar. 1, 2013).

5. See Eingestellt von Florian Mueller, RIM Loses Arbitration, Has to Agree with Nokia on Royalties or Stop Selling WiFi Products, Foss PATENTS (Nov. 28, 2012, 11:07 AM), http://www.fosspatents.com/2012/11/rim-loses-arbitration-has-to-agree-with.html.

6. Gen. Instrument Corp. v. Microsoft Deutschland $\mathrm{GmbH}$, Landgericht Mannheim [LG] [Regional Court of Mannheim] May 2, 2012, (Ger.), available at http:// www.scribd.com/doc/94523005/Translation-of-Mannheim-2O240-Ruling-Motorola-v -Microsoft; InT'L Telecomm. Union, H.264: AdVAnced VideO Coding For GeneriC AudiOvisuAl SERVICES (2013), available at http://www.itu.int/rec/T-REC-H.264.

7. Microsoft Corp. v. Motorola, Inc., 696 F.3d 872, 879 (9th Cir. 2012). The injunction would have prohibited Microsoft from selling the Xbox 360 or any product incorporating Windows 7 or Windows Media Player 12.

8. The label "PAE" was promoted by the FTC in its 2011 report to distinguish a specific type of non-practicing entity (NPE). FTC, THE Evolving IP MARKeTPLACE: Aligning PAtent Notice And Remedies with COMPetition 8 n.5 (2011), available at http://www.ftc.gov/os/2011/03/110307patentreport.pdf. 
are often referred to disparagingly as "patent trolls," is outside the scope of this Article, but they too have sought hundreds of millions of dollars in royalties from the deep pockets of technology giants. ${ }^{9}$

This Article focuses on disputes concerning patents that are essential to technology standards. During the creation of a standard, the standard-setting organization (SSO) will typically require members who hold standard essential patents (SEPs) to make a commitment to license these patents on fair, reasonable, and non-discriminatory (FRAND) terms. ${ }^{10}$ However, the legal effect of this FRAND commitment is sometimes unclear, and this lack of clarity is especially problematic when the dispute is international in nature because jurisdictions may view these commitments very differently. U.S. courts, for example, may be more willing to recognize third-party beneficiary rights in the FRAND contract than some European jurisdictions. ${ }^{11}$ U.S. courts may also apply the equitable test of eBay v. MercExchange $e^{12}$ to foreclose injunctions when the infringed patent is an SEP. ${ }^{13}$ On the other hand, U.S. courts are less likely to apply antitrust law to foreclose anticompetitive use of SEPs than European courts. ${ }^{14}$

With this Article, we aim to reframe the discussion of FRAND commitments in a way that will be beneficial to the many participants affected by disparate treatment of licensing commitments made in the standard-setting context. The conceptual framework we propose characterizes FRAND commitments as creating a property interest, instead of merely creating a contract or a condition that affects a competitive relation. To address the question of remedies, we apply this theory to support a contention that injunctions against the use of SEPs would be adverse to the public interest.

As discussed in Part II, FRAND commitments are awash in case law and court decisions but are bereft of a discussion of their theoretical underpinnings. This Article fills that void by developing a conceptual framework for understanding

9. See, e.g., VirnetX Inc. v. Apple Inc., No. 6:10-CV-417, 2013 WL 692652 (E.D. Tex. Feb. 26, 2013); MobileMedia Ideas LLC v. Apple Inc., 890 F. Supp. 2d 508 (D. Del. 2012); Charles Arthur, VirnetX Adds iPhone 5 to New Apple Lawsuit After $\$ 368 m$ Trial Win, THE GuARDiAn (Nov. 9, 2012, 1:21 PM), http://www.guardian.co.uk/technology/2012/nov/09 /apple-virnetx-patent-iphone-5 (noting ongoing litigation); Christina Bonnington, Jurors Say Apple iPhone Infringes on Three MobileMedia Patents, WIRED (Dec. 13, 2012, 3:23 PM), http://www.wired.com/gadgetlab/2012/12/iphone-infringes-patent/ (quoting Florian Mueller for the premise that MobileMedia is a patent licensing and assertion entity, though it undertakes its activities on behalf of Sony, Nokia, and MPEG-LA). On VirnetX's website, the company explicitly states that their "portfolio of intellectual property is the foundation of [their] business model." Gabriel Patent Licensing, VIRNETX, http://virnetx.com /licensing/patent-licensing-2/. Thus, it is probably not unreasonable to categorize VirnetX as a patent assertion entity.

10. Because we frequently use acronyms in this Article, we have included a Glossary in the Appendix.

11. Microsoft, 696 F.3d at 888 ("German courts, unlike some U.S. courts and commentators, do not interpret the RAND commitment to create a contract enforceable by third parties or to foreclose injunctive relief.").

12. 547 U.S. 388 (2006).

13. See Microsoft, 696 F.3d at 877.

14. See infra Part III.B.2.a. 
FRAND commitments using property theory. This Article focuses on FRAND commitments and five problems arising repeatedly with respect to these agreements: (1) whether the FRAND obligation transfers to subsequent assignees of the patent; (2) whether FRAND commitments should apply to patents acquired after making the FRAND commitment (i.e., after-acquired patents); (3) whether nonmembers of the SSO should have the same standing as SSO members to enforce FRAND commitments; (4) how to understand the word "essential" in the phrase "standard essential patents" (SEPs); and (5) whether the FRAND commitment should impact remedies available in patent litigation, either from the perspective of the patent owner or the beneficiary of the FRAND commitment.

Different types of analysis were required for each of these five problems. For the nonmember and after-acquired problems, resolution could be reached largely through analysis of accepted legal approaches. To understand essentiality, we evaluated the problem from a more practice-based approach, relying on representations by industry representatives with whom we consulted. Our analysis of the issues relating to remedies shifted more toward the theoretical, with emphasis on the well-established approach of Calabresi and Melamed to property and liability rules, while applying the current law pertaining to injunctions in patent litigation. We found, however, that the currently applied legal theories are insufficient to support the transferability of FRAND commitments, and that in fact some existing case law suggests that a property theory offers a better vehicle for transferability. To our knowledge, this Article represents the first attempt at applying U.S.-based property law and theory to the issue of FRAND commitment transferability. As discussed in Part III, our property approach begins with the theoretical foundations provided by Hohfeldian analysis of jural relations, before narrowing the focus to a more specific analogy to the law of servitudes.

This Article is organized as follows. In Part I, we introduce some of the major issues that arise in the context of interoperability and standards, with a focus on the presence of FRAND commitments. ${ }^{15}$ This Part includes a detailed hypothetical to illustrate what we view as some of the most significant potential issues. In Part II, we analyze how the law may apply to FRAND commitments under several different theories, how some of these issues have been treated by courts thus far, and how current theories apply to the problems raised in our hypothetical. In Part III, we expound on a new theory that FRAND commitments can be viewed as creating an interest analogous to a servitude in real property. In Part IV, we examine the issue of whether the owners of SEPs should be able to obtain

15. In the United States, these terms are sometimes referred to as "reasonable and nondiscriminatory," or RAND. Judge Posner wrote recently that "the word 'fair' adds nothing to 'reasonable' and 'nondiscriminatory."' Apple, Inc. v. Motorola, Inc., 869 F. Supp. 2d 901, 911-12 (N.D. Ill. 2012). However, because "FRAND" is often used to describe these terms in the United States anyway, and it is how these terms are typically described in analysis elsewhere (including Europe), we use the term FRAND in this report instead of RAND to better encompass the international scope of the discussion. Adopting the acronym "FRAND" might also simplify searches for relevant information, as fewer words in the English language contain the consecutive letters F-R-A-N-D than contain the consecutive letters R-A-N-D. 
injunctions against the implementers of standards for which the SEP owners made FRAND commitments.

\section{PATENTS, ESSENTIALITY, STANDARDS, AND SSO POLICIES}

\section{A. Patents and Innovation}

There is much criticism of patent litigation and the potential effects it can have on innovators. Some claim that patent litigation may have the effect of stifling innovation, ${ }^{16}$ but David Kappos, the former director of the United States Patent and Trademark Office (USPTO), stated recently that the smartphone patent wars are themselves a sign that the U.S. patent system works to promote innovation. ${ }^{17}$

Regardless of which side has a more persuasive argument, the interplay between law, technology, and society is abundantly clear. This is a high technology world, shaped by computing, networking, and communications technologies. Many of these technologies are protected by the intellectual property laws of the United States. Congress's authority to regulate patents stems from the Constitution, which empowers Congress to enact laws to "promote the Progress of Science and useful Arts." 18 Thousands of innovations over the last half century have come together to shape modern computing. Supporters of modern intellectual property law attribute many of these innovations to the protections afforded inventors under patent law. ${ }^{19}$

Inventors who successfully obtain a patent are granted a legal monopoly for the life of the patent, which is currently twenty years from the date of first submission of the application. ${ }^{20}$ During this patent period, the inventor who retains ownership of the patent can recoup her investment, with three main options available to do so: by being the only person allowed to practice the patent, by licensing the patent to others and collecting royalties, or by practicing the patent and granting licenses

16. Charles Duhigg \& Steve Lohr, The Patent, Used as a Sword, N.Y. TimeS, Oct. 8, 2012, at A1, available at http://www.nytimes.com/2012/10/08/technology/patent-wars -among-tech-giants-can-stifle-competition.html.

17. Steve Lohr, Smartphone Patent Wars Show the System Works, Patent Chief Says, N.Y. Times Bits Blog (Nov. 20, 2012, 3:25 PM), http://bits.blogs.nytimes.com/2012/11/20 /smartphone-patent-wars-show-the-system-works-patent-chief-says. For more discussions about the possible effects of patents and patent litigation on innovation, see Michael A. Heller \& Rebecca S. Eisenberg, Can Patents Deter Innovation? The Anticommons in Biomedical Research, 280 SCI. 698 (1998); see also U.S. DeP'T of Health \& Human Servis., Gene Patents and Licensing Practices and Their Impact on Patient Access to Genetic Tests: Report of the Secretary's Advisory Committee on Genetics, Health, AND SOCIETY (2010), available at http://oba.od.nih.gov/oba/SACGHS/reports/SACGHS patents_report_2010.pdf ("The Committee also found that patents have been used to narrow or clear the market of existing tests, thereby limiting, rather than promoting availability of testing.").

18. U.S. Const. art. $1, \S 8, \mathrm{cl} .8$.

19. See Mark A. Lemley, Intellectual Property Rights and Standard-Setting Organizations, 90 CALIF. L. REV. 1889, 1892 (2002) (referencing and contesting the standard economic theory of IP rights, which argues that weaker IP rights will result in decreased innovation).

20. 35 U.S.C. $\S 154(a)(2)(2006)$. 
simultaneously. Hovenkamp notes that organizations may also obtain patents for defensive motives, such as allowing the organization to practice inventions in a way that minimizes the threat of patent litigation. ${ }^{21}$

Modern innovation typically builds on earlier innovation, in a way that Professor Carl Shapiro likens to standing atop a pyramid rather than, as Newton originally described the progress of science, standing "on the shoulders of giants." 22 The pyramid metaphor communicates that often, one innovation relies on many earlier innovations, which each in turn rely on even earlier innovations. It logically follows that many modern inventions may rely to some extent on technologies that are still covered by patents held by others. ${ }^{23}$ Some scholarship indicates that in areas where innovation is cumulative - that is, more like the pyramid metaphorstrong intellectual property (IP) rights can impede innovation. ${ }^{24}$

In this IP-centric context, patent litigation typically follows a fairly predictable pattern. A patent holder may notify the alleged infringer that a particular product infringes on his technology and demand royalties. The patent holder may then file suit against the alleged infringer if the parties are unable to reach an agreement. The patent holder's goal in an infringement action may be damages, often in the form of court-ordered royalty payments, or an injunction to prevent the defendant from practicing the patent holder's invention. ${ }^{25}$ Professor Golden notes that historically, if the patent holder thought he could obtain an injunction, the patent holder might also use the potential injunction as leverage to obtain a settlement for a higher royalty payment than the alleged infringer would have been willing to pay otherwise. ${ }^{26}$ The alleged infringer is likely to defend by arguing either that the asserted patent was invalid, or that if it was valid, there was no infringement. ${ }^{27}$

21. See Herbert Hovenkamp, Antitrust and the Movement of Technology, 19 GEO. MASON L. REV. 1119, 1137 (2012).

22. Carl Shapiro, Navigating the Patent Thicket: Cross Licenses, Patent Pools, and Standard Setting, in 1 InNOVATION Policy AND THE ECONOMY 119, 119-20 (Adam B. Jaffe, Josh Lerner \& Scott Stern eds., 2000), available at http://www.nber.org/chapters /c10778.pdf; see also Peter S. Menell, The Property Rights Movement's Embrace of Intellectual Property: True Love or Doomed Relationship?, 34 ECOLOGY L.Q. 713, 752 (2007) ("[T]he cumulative nature of innovation means that almost all innovations are linked to other innovations to some degree.").

23. See Adam Speegle, Note, Antitrust Rulemaking as a Solution to Abuse of the Standard-Setting Process, 110 Mich. L. REV. 847, 848 (2012) (noting that the majority of consumer electronics are "aggregations of independent patented technologies that are packaged together").

24. Lemley, supra note 19, at 1948 (referencing economic scholarship); see also Menell, supra note 22, at 753 ("[T]he trend of digital technology toward greater collaborative creativity and costly enforcement seems unlikely to support traditional conceptions of ownership and control.").

25. See John M. Golden, Principles for Patent Remedies, 88 Tex. L. Rev. 505, 514 (2010).

26. See id. at 508 .

27. See 35 U.S.C. $\S 282$ (2006) (listing available defenses to assertions of patent infringement). 


\section{B. Interoperability and Standards}

These patterns of arguments regarding patent infringement and validity also arise in the context of standardized technologies. When this happens, the impact is potentially much broader. James Surowiecki of Wired asserted in 2002 that "without standardization there wouldn't be a modern economy." 28 While this statement was put forth largely with mass production and mass communication in mind, it is similarly true for the modern computing industry.

The complications arising from the aggregate nature of innovation are compounded by the modern need for technologies - especially communication technologies - to be interoperable. The ability of gadgets to interact with each other is of paramount importance in this age in which information is exchanged across thousands of miles in a matter of seconds. ${ }^{29}$ Device interoperability gives consumers more options in how they use technologies. Interoperability also increases network effects - that is, the positive effects that emerge as more people adopt the technology. ${ }^{30}$ Network effects are especially prevalent in the Internet, computer, and telecommunications (ICT) industries. This is partly because the cost of creating the technology decreases as more users adopt the technology and partly because, as Merges and Kuhn observe, innovations in these industries are the most effective when large numbers of people adopt them, and one way to encourage wide adoption is to standardize the technology. ${ }^{31}$

In the ICT industries, the establishment of standards is important for the twin goals of achieving higher levels of interoperability and obtaining greater network effects. Sometimes, an industry may establish de facto standards through wide usage, ${ }^{32}$ but other times, standard-setting organizations (SSOs) formally establish standards through detailed processes. ${ }^{33}$ SSOs are generally voluntary collectives in which representatives from multiple private companies, who are often competitors of each other, work together to establish technology standards. ${ }^{34}$ Speegle notes that consumers and industry both benefit from an efficient use of the standard-setting

28. James Surowiecki, Turn of the Century, WIRED, Jan. 2002, at 85, available at http:// www.wired.com/wired/archive/10.01/standards.html.

29. See Stacy Baird, The Government at the Standards Bazaar, 18 STAN. L. \& PoL'Y REV. 35, 38 (2007) (emphasizing the importance of interoperability in information technology).

30. Robert P. Merges \& Jeffrey M. Kuhn, An Estoppel Doctrine for Patented Standards, 97 CALif. L. Rev. 1, 4 (2009) ("Standardization spurs network effects because a program that interoperates with a variety of programs and files is more valuable than one that works only in isolation.").

31. See id. at 5 (stating that in the case of "network goods" like software, a product becomes more valuable when more people use it); $i d$. at 7 (stating that standardization allows for greater interoperability between different software components).

32. The Blu-ray/HD DVD conflict is an example of a "standard war" in a de facto standard-setting context. In lieu of a separate organization determining the final specifications, the winner of the standard war was determined by the market. Speegle, supra note 23 , at 848 .

33. Lemley, supra note 19, at 1898-99.

34. See id. at 1947 (noting that SSOs "are built on agreements among horizontal competitors"). 
process because the resulting technologies are more interoperable and are more quickly adopted by consumers. ${ }^{35}$

Because of the aggregate nature of innovation and the prevalence of patents in the ICT industries, many standards set by SSOs implicate proprietary technologies that are still covered by patents. This increases the possibility of abuse, either through patent ambush or patent holdup. Patent ambush in the standards context might arise where a patent holder learns that a proposed standard implicates claims covered by his patent or patent application but does nothing either to inform the SSO or to assert his rights until after the standard has been adopted. ${ }^{36}$ On the other hand, Merges and Kuhn describe patent holdup as arising when a patent holder refuses to license a relevant patent on expected terms, thus "holding up" the progress of disseminating a new technology, regardless of whether the SSO was aware of the patent holder's interest when creating the standard. ${ }^{37}$ Chien and Lemley note that patent holdup is an especially pernicious threat in the case of multicomponent products where the claims of the asserted patent cover only a small part of the product. ${ }^{38}$ Thus, the importance of protecting IP rights must be balanced against preventing abusive tactics in order to protect consumers, competition, and innovation in these industries. ${ }^{39}$

SSOs, aware of the potential abuse of patents in the context of standards, often adopt intellectual property rights (IPR) policies aimed at curbing such abuses to remove potential barriers to standard adoption. ${ }^{40}$ For instance, to facilitate the adoption of standards, SSOs often require patent holders to agree to license essential patents on FRAND terms. ${ }^{41}$ Layne-Farrar, Padilla, and Schmalensee suggest that FRAND commitments are intended to curb possible attempts to exploit the increased market power that comes with owning a patent that is used in a standard. ${ }^{42}$

35. Speegle, supra note 23, at 848-49.

36. M. Sean Royall, Amanda Tessar \& Adam Di Vincenzo, Deterring "Patent Ambush" in Standard Setting: Lessons from Rambus and Qualcomm, 23 ANTITRUST, no. 3, Summer 2009, at 34, 34.

37. See Merges \& Kuhn, supra note 30 , at 10 (stating that patent holdup can either be in the form of "bait-and-switch," where the patentee increases the licensing cost unexpectedly, or "snake-in-the-grass," when it is a third party that unexpectedly asserts a patent). Merges and Kuhn refer to snake-in-the-grass holdups as "strategic rent-seeking." Id. at 25.

38. Colleen V. Chien \& Mark A. Lemley, Patent Holdup, the ITC, and the Public Interest, 98 CORNELL L. REV. 1, 39 (2012).

39. See id. at 6; Merges \& Kuhn, supra note 30, at 49. Chien and Lemley also note that much patent infringement litigation in this sort of context involves inadvertent infringement. Chien \& Lemley, supra note 38, at 6.

40. See, e.g., InT'L Electrotechnical Comm'n, InT'L Org. For Standardization \& Int'L Telecomm. Union, Guidelines for Implementation of the Common Patent POLICY FOR ITU-T/ITU-R/ISO/IEC (2d ed. 2012), available at http://www.itu.int/dms_pub /itu-t/oth/04/04/T04040000010003PDFE.pdf.

41. See id. at 7-8.

42. Anne Layne-Farrar, A. Jorge Padilla \& Richard Schmalensee, Pricing Patents for Licensing in Standard-Setting Organizations: Making Sense of FRAND Commitments, 74 ANTITRUST L.J. 671, 672 (2007). 
However, companies in high technology industries often possess large patent portfolios, making it difficult for the company representatives who are involved with the standard-setting process to know if the company owns essential patents. Additionally, a patent may be bought and sold multiple times during its lifetime, and these patent transfers may complicate FRAND commitments. Patent transfers in the standards context raise two important questions related to the patents at issue and the implicated parties: (1) has the new patent holder obtained a patent covering a technology that is subject to a FRAND commitment, and (2) is the new patent holder a party that will be bound by a FRAND commitment?

Once a standard is set, standard adopters are locked in, and switching costs are often very high if new circumstances arise-for example, if a patent owner starts suing every company that makes products that comport with the standard. ${ }^{43}$ It is likely to be difficult to anticipate where these possible abuses might come from. A company may appear suspicious if it acquires a large number of patents, but the company might be acquiring these patents for defensive purposes, with no intention to assert them in litigation except in counterclaims. Similarly, Merges and Kuhn warn that post-standard patenting may be a sign of bad faith strategic rent-seeking, but a study by Layne-Farrar indicates that less than a third of patents obtained after a specific standard was finalized were opportunistic. ${ }^{44}$ But if patent holdup does occur, this can increase the cost of the technology for consumers and also cause significant delays and inefficiencies in the standard-setting process. ${ }^{45}$

One of the most pervasive issues in the SSO context is that FRAND is rarely if ever defined in advance of a conflict. ${ }^{46}$ SSOs generally do not get involved with setting licensing terms, which Layne-Farrar, Padilla, and Schmalensee note may be in part due to the possible antitrust concerns if an SSO existed as an organization of competitors that also discussed pricing strategies. ${ }^{47}$ Instead, SSOs adopt vague language requiring fairness and reasonableness, leaving it to the courts to determine what license terms would be fair and reasonable. ${ }^{48}$ The courts and the parties in the

43. See Merges \& Kuhn, supra note 30, at 6 (noting the problems of lock-in and collective switching costs in the standards context).

44. Compare id. at 25 (suggesting that the timing of patent applications might indicate bad faith on the part of the applicant), with Anne Layne-Farrar, Innovative or Indefensible? An Empirical Assessment of Patenting Within Standard Setting, InT'L J. IT STANDARDS \& StANDARDiZATION RES., July-Dec. 2011, at 1, 13 (noting that the author's analysis of forward citations indicates that only between $10 \%-30 \%$ of patents obtained after a standard is set are actually opportunistic).

45. Speegle, supra note 23, at 849 .

46. See, e.g., Microsoft Corp. v. Motorola, Inc., No. C10-1823JLR, 2013 WL 2111217 (W.D. Wash. Apr. 25, 2013) (determining an appropriate FRAND royalty).

47. Layne-Farrar et al., supra note 42, at 678-79. It may be worthwhile to consider the possibility of creating a limited antitrust exception, such as that available for insurance companies under the McCarran-Ferguson Act. 15 U.S.C. $\S \S 1011-1015$ (2006). Such an exception could avoid possible antitrust concerns raised by the activities of some SSOs or patent portfolio management entities. Such a proposal would be driven in part by the market benefits that might accrue if patentees and/or licensees could, for example, share information related to pricing and licensing payments. However, this substantial and perhaps controversial reform proposal is beyond the scope of this Article.

48. See Speegle, supra note 23, at 853 (arguing that the FRAND commitments are too 
conflict may then apply economic models or legal tests to determine the value of the patent's contribution to the standard or the whole product, ${ }^{49}$ and this type of approach may be taken by scholars as well. ${ }^{50}$

\section{Essential Patents in Standards}

Before we turn to a more thorough examination of the behavior of SSOs, we must explain one of the foundational issues to which we will refer: essentiality. By doing so, this Part will also lay the groundwork for resolving one of the five issues that this Article examines.

Above, we noted that one of the major questions that arises in the context of FRAND commitments and patent transfers concerns which patents the agreements apply to. ${ }^{51}$ This question often turns on the concept of essentiality. Many times, standards will rely on proprietary technologies still under patent, often called SEPs. The IPR policies of SSOs often refer to SEPs as being covered by FRAND commitments, and require SSO members to disclose SEPs that the members own. ${ }^{52}$ When disclosed, the term "declared essential patents" may be used to describe these patents, indicating the unverified nature of the patent's essentiality. ${ }^{53}$

But what are SEPs? Often, SEPs are characterized as technologically essential patents, ${ }^{54}$ and this technological essentiality is tied closely with the interoperability focus of the standard. However, the concept of essentiality encompasses many ideas, and discussions of essentiality sometimes use the same term to refer to different ideas. Lemley warns that an understanding of essentiality that is too broad threatens to complicate the process of IP disclosures, ${ }^{55}$ but in our view an understanding that is too narrow also threatens to undervalue certain technologies. In this Part, we aim to explain and clarify some of the possible meanings of essentiality in the context of standards.

When the Department of Justice (DOJ) evaluates entities for possible antitrust issues, the DOJ may issue business review letters. ${ }^{56}$ The DOJ has evaluated several

vague and "often provide at most a questionable foundation on which to base litigation over patent licensing disagreements").

49. See, e.g., Microsoft, 2013 WL 2111217, at *13.

50. See Layne-Farrar et al., supra note 42, at 676. Layne-Farrar, Padilla, and Schmalensee apply economic models to various possible circumstances, and they conclude that the equilibrium royalty rate will be highest when there is no competition, lower when there is imperfect competition, and minimal when there is perfect competition. Id. at 692-93.

51. See supra Part I.B.

52. See, e.g., InT'L EleCtroteChNiCAl Comm'N ET AL., supra note 40, at 2.

53. See, e.g., Microsoft Corp. v. Motorola, Inc., 696 F.3d 872, 876, 878 (9th Cir. 2012).

54. E.g., European Telecomms. Standards Inst., ETSI Intellectual Property Rights Policy, in ETSI Rules of Procedure 35, 41 (2011), available at http://www.etsi.org/images letsi_ipr-policy.pdf (defining "essential" as referring to technical, but not commercial, essentiality).

55. See Lemley, supra note 19, at 1959 (warning that the inclusion of "unnecessary patents will complicate the disclosure and licensing processes").

56. 28 C.F.R. $\S 50.6$ (2012). 
patent pools relating to technology standards, including MPEG-LA in $1997^{57}$ and two pools relating to the DVD standard in $1998^{58}$ and $1999 .{ }^{59}$ The DOJ ultimately permitted the actions of these entities, with one of the important factors being that each pool was limited to essential patents. ${ }^{60}$ However, the DOJ did not address how essentiality should be interpreted, just whether the pool's approach to essentiality was acceptable. ${ }^{61}$ In the MPEG-LA letter, the DOJ noted with approval that MPEG-LA's patent pool was limited to patents that were "essential to compliance" with the MPEG-2 standard. ${ }^{62}$ In the First DVD Letter, the DOJ approved of the pool's definition of essentiality as being "necessary (as a practical matter) for compliance" with the standard ${ }^{63}$ In the Second DVD Letter, the DOJ approved of the pool's definition of essential patents as being patents that would be "necessarily infringed," or for which "there is no realistic alternative."

After discussing essentiality with industry members ${ }^{65}$ we posit that there are three primary possible types of essentiality: (1) core essential, meaning the patent is technologically essential to a core function of the standard; (2) noncore essential, meaning the patent is technologically essential to an optional function of the standard; and (3) commercially essential, meaning the patent's claims cover an option that is not technologically essential to the standard, but other factors exist making the patent commercially essential. A standard may also discuss technologies covered by "non-essential" patents, meaning the patent claims of a single patent may describe one of several alternatives for implementing the core or noncore features described by the standard.

These three primary options also partially mirror the approaches taken with respect to the MPEG-2 and DVD standards, as approved by the DOJ. For the

57. Letter from Joel I. Klein, Acting Assistant Att'y Gen., Antitrust Div., DOJ, to Gerrard R. Beeney, Sullivan \& Cromwell (June 26, 1997) [hereinafter MPEG-LA Letter], available at $\mathrm{http}: / / \mathrm{www} . j u s t i c e . g o v /$ atr/public/busreview/215742.pdf.

58. Letter from Joel I. Klein, Assistant Att'y Gen., Antitrust Div., DOJ, to Garrard [sic] R. Beeney, Sullivan \& Cromwell (Dec. 16, 1998) [hereinafter First DVD Letter], available at http://www.justice.gov/atr/public/busreview/2121.pdf.

59. Letter from Joel I. Klein, Assistant Att'y Gen., Antitrust Div., DOJ, to Carey R. Ramos, Paul, Weiss, Rifkind, Wharton \& Garrison (June 10, 1999) [hereinafter Second DVD Letter], available at http://www.usdoj.gov/atr/public/busreview/2485.pdf.

60. See First DVD Letter, supra note 58, at 15; MPEG-LA Letter, supra note 57, at 16; Second DVD Letter, supra note 59, at 16.

61. See First DVD Letter, supra note 58, at 11; MPEG-LA Letter, supra note 57, at 11; Second DVD Letter, supra note 59, at 13.

62. MPEG-LA Letter, supra note 57, at 9.

63. First DVD Letter, supra note 58, at 11.

64. Second DVD Letter, supra note 59 , at 3.

65. In the initial stages of our research, we received feedback from industry professionals at companies including Google, Microsoft, Research In Motion, and IBM. This collaboration was made possible by our participation in the Symposium on Management of Intellectual Property in Standard-Setting Processes, which was held in October 2012 by the Board on Science, Technology, and Economic Policy at the National Academy of Sciences. Bd. on Sci., Tech. \& Econ. Policy, Symposium on Management of Intellectual Property in Standard-Setting Processes Agenda, National ACADEMIES, http://sites.nationalacademies .org/PGA/step/PGA_070838. 
MPEG-2 standard, "essential to compliance"66 is fairly strong wording that we would interpret as referring to core essentiality. As referenced in the First DVD Letter, "necessary (as a practical matter) for compliance" ${ }^{67}$ can be understood as including core essentiality and noncore essentiality, and potentially also commercial essentiality. The Second DVD Letter's reference to patents for which "there is no realistic alternative" ${ }^{68}$ indicates that this third pool might consider commercially essential patents to also be essential.

Based on our communications with industry representatives, we posit that commercial essentiality may be understood along a continuum, from broad to intermediate to narrow. Under our broad definition, a technology would be commercially essential when nearly unanimous market demand for the option renders it necessary for competitors to include that option in order to compete. Our intermediate view of commercial essentiality emphasizes technologies that enable interoperability, which developers of complementary technology will need to use in order to make their products compatible. Thus, while the broad view might characterize patented features as commercially essential based on their popularity in the market, the intermediate view relies on popularity of a technology that is tied to interoperability. Our narrow definition, in contrast, would limit commercial essentiality to non-essential patents that are nevertheless included within the standard. There are two main options for a non-essential patent to be considered a commercially essential patent: (1) the alternative technologies would be too costly, leaving only one technology that is commercially feasible; or (2) one of the options is preferred over others by such a great margin that it is not commercially feasible to instead implement one of the alternatives.

Opinions vary as to whether commercially essential patents should be treated the same as technologically essential patents. Lemley argues that FRAND commitments should only apply to essential patents, reasoning that allowing FRAND commitments to apply to non-essential patents would "complicate the disclosure and licensing processes" and could result in members disclosing patents with the twin goals of (1) avoiding nondisclosure liability and (2) obtaining royalty payments. ${ }^{69}$ But Lemley characterizes patents that are "necessary as a practical matter" as being essential, ${ }^{70}$ echoing the definition of essentiality referenced in the First DVD Letter, which suggests that Lemley might view essential patents as including some commercially essential patents, not just technologically essential patents. It is unclear, however, whether Lemley would adopt a broad, intermediate, or narrow characterization of commercial essentiality. On the other hand, Professor Shapiro defines essential patents as patents that are "necessary to comply with [the] standard," similar to the "essential to compliance" definition referenced in the MPEG-LA Letter. ${ }^{72}$ This narrower wording suggests that Professor Shapiro would view the term "essential patents" as being limited to technologically essential

66. MPEG-LA Letter, supra note 57, at 1.

67. First DVD Letter, supra note 58, at 3.

68. Second DVD Letter, supra note 59, at 3.

69. Lemley, supra note 19, at 1959.

70. Id. at 1958.

71. Shapiro, supra note 22, at 136.

72. MPEG-LA Letter, supra note 57, at 9. 
patents. If this "necessary to comply" language is taken literally, Shapiro's position might also be read as limiting technological essentiality to core essential patents. A related problem concerns the possibility that non-essential patents could later become commercially essential, and whether these newly essential patents should be treated as subject to earlier FRAND commitments.

SSOs vary in how they address the question of technologically versus commercially essential patents. ${ }^{73}$ Whether a technology is considered an SEP is largely determined by the SSO's IPR policy. Commercially essential patents are considered SEPs by only a minority of SSOs. The Institute of Electrical and Electronics Engineers Standards Association (IEEE-SA) is one of the few SSOs that permits commercially essential patents to be SEPs, and the IEEE-SA's definition adopts the narrow view of commercial essentiality that only covers otherwise non-essential technologies that were already mentioned in the standard. ${ }^{74}$

At this point, an illustration may be helpful. One aspect of the smartphone patent war concerns the use by competitors of some of the patented design elements of Apple products, like slide-to-unlock. ${ }^{75} \mathrm{~A}$ broad definition of commercially essential might characterize this feature as commercially essential if nearly all smartphone users demand it. Slide-to-unlock is an example of a user interface technology that may be very popular but has little if anything to do with the underlying functionality of a smartphone. Google takes an intermediate approach to commercial essentiality, arguing that some popular technologies are so central to interoperability and necessary for complementary technologies that they should be viewed as de facto standards, with relevant patents treated as SEPs. ${ }^{76}$ Slide-tounlock would not be considered commercially essential under an intermediate definition because it is a feature that only concerns the user interface and not interoperability. The IPR policy of IEEE-SA provides an example of the narrow view of commercial essentiality, defining an "essential patent claim" as a claim that "was necessary to create a compliant implementation of either mandatory or optional portions" of the standard, for which there is "no commercially and technically feasible non-infringing alternative.,"77 Slide-to-unlock would probably not be considered narrowly commercially essential, because it is likely that the designers of a product could come up with many different ways to activate a device. $^{78}$

73. Compare European Telecomms. Standards Inst., supra note 54, at 41 (excluding commercial essentiality), with Inst. OF ElEC. \& ElECS. ENG'RS STANDARDS AsS'N, IEEE-SA STANDARDS BOARD BYLAWS $§ 6.1$ (2012), available at http://standards.ieee.org/develop /policies/bylaws/sb_bylaws.pdf (including commercial essentiality).

74. InSt. of ElEC. \& EleCs. ENG'RS StANDARdS AsS'N, supra note 73.

75. Apple, Inc. v. Samsung Elecs. Co., 877 F. Supp. 2d 838, 881 (N.D. Cal. 2012).

76. John Paczkowski, Google Says Some Apple Inventions Are So Great They Ought to Be Shared, All ThINGs D (July 20, 2012, 3:05 PM), http://allthingsd.com/20120720/google -claims-popularity-has-made-some-apple-patents-de-facto-essentials/.

77. InSt. OF EleC. \& EleCs. Eng'RS StANDARds Ass'N, supra note 73, § 6.1 (emphasis added).

78. For example, consider our device activation technique in the hypothetical set forth below in Part I.E, where we consider a Widget activation method that involves waving the Widget in the air like a magic wand. 
In our view, SSOs should be permitted to consider commercially essential patents as SEPs but should make it explicit in their IPR policies if they do so. In the absence of an explicit provision, it may be appropriate to limit the term "essential patent" to one or both types of technological essentiality. If commercially essential patents are considered to be SEPs, we suggest adopting the narrow definition of commercial essentiality. The narrow definition encourages innovation above the standard, since any such improvements would be treated as proprietary technologies instead of being swallowed by the standard. The biggest problem with the broad definition of commercial essentiality is that there is no ex ante determination-the more successful the improvement, the more likely the improvement will be declared to be a standard, essential at some unknown future time, thus reducing the value that an innovator can realize by improving on a standard. Regardless, parties would still be free to include broadly commercially essential patents in licensing negotiations.

Even if a clear definition of essentiality is adopted, that will not resolve all of the problems that companies have when determining whether they own patents that should be declared as essential to the SSO. This determination requires the SSO members to search through all of the patents that their respective companies own, which some compare to looking for a needle in a haystack. ${ }^{79}$ But we expect that if this is a known variable, the above characterizations of essentiality will greatly assist in the process of categorizing known patents into the proper type of essentiality. It is to the difficulty of meeting SSOs' requirements that we now turn.

\section{Requirements Imposed by SSOs Prior to Standard Adoption}

SSOs generally adopt IPR policies that set forth their members' obligations with regard to intellectual property implicated by the standard. ${ }^{80}$ During the standard-setting process, a board or committee may request that members disclose relevant patents, and it may also seek commitments from patent holders to license these patents on either royalty-free (FRAND-RF) or FRAND terms to anyone who requests a license. $^{81}$

79. Layne-Farrar et al., supra note 42, at 677 (referencing findings of empirical work by Benjamin Chiao, Josh Lerner \& Jean Tirole). Declaring that a patent is essential is often a judgment call. Id.

80. E.g., European Telecomms. Standards Inst., supra note 54, at 35-36 (requiring members to disclose essential patents and commit to licensing essential patents on FRAND terms).

81. FRAND-RF and FRAND terms are often seen as alternatives to one another. In the standards context, parties occasionally cross-license on FRAND-RF terms, as Apple allegedly offered to do if ETSI adopted its design for a new nano-SIM card as essential to a new standard. Eric Slivka, Apple Offers Royalty-Free Patent Licenses to Push Proposed Nano-SIM Standard, MACRuMORS.COM (Mar. 26, 2012, 6:47 AM), http://www.macrumors.com/2012 /03/26/apple-offers-royalty-free-patent-licenses-to-push-proposed-nano-sim-standard/. In some cases, SSOs might also treat FRAND-RF licenses as a punitive measure, as in the case of SSOs that include provisions in their IP policies requiring members to license on FRANDRF terms if they own essential patents that they fail to disclose. E.g., VITA STANDARDS ORG., VSO Policies AND PROCEDURES 14 (rev. 2.6 2009), available at http://www.vita.com/home /VSO/vso-pp-r2d6.pdf. 
Depending on the member's business model, however, requiring the disclosure of all potential SEPs might be very costly and burdensome. A member company with a large patent portfolio, for instance, might have hundreds of patents that are potentially relevant to a standard that is being developed. In such a situation, the member would have to read through each claim of every potentially relevant patent to identify patents that might be essential to a standard that has not yet been finalized or adopted. Having attorneys review all of these patents would likely be cost prohibitive, but the main alternative to doing so would be to assign the task to experienced technical professionals who are familiar with the proposed standard, thereby taking these individuals away from their normal responsibilities.

Thus, companies may have an incentive to not undertake expensive investigations of their own patent portfolios for the purpose of disclosing specific patents as potential SEPs. However, such companies may be more willing to make a blanket commitment to the SSO to license any SEPs on FRAND terms without identifying the SEPs individually. Such blanket commitments can save time on the front end but will not obviate the need to eventually examine the patent portfolio for SEPs, especially if part of the portfolio is being assigned to another company.

If the company makes a broad commitment, what happens if one of the patents that might be covered is then transferred? The IPR policy of the International Telecommunication Union (ITU) is seemingly written with this situation in mind. In section 7, concerning assignment and transfer of patent rights, the ITU requires members to make reasonable efforts to secure an assignee's agreement to be bound by commitments that the patent owner reasonably believes it made to the ITU. ${ }^{82}$ Thus, the question becomes whether there is a reasonable belief that the transferred patent was covered by this broad commitment.

Broad commitments would likely be less appealing to patent owners when the SSO requires licensing to be on royalty-free terms. Because patent owners would be unlikely to make broad commitments to license their entire patent portfolio on a royalty-free basis, these broad commitments are likely to only appear when the SSO emphasizes FRAND commitments and the availability of royalties. Some SSOs allow patent owners to choose between committing to FRAND-RF licensing and FRAND licensing. ${ }^{83}$

FRAND commitments are generally between the patent holder and the SSO. However, apart from the amorphous language requiring that licenses be fair, reasonable, and nondiscriminatory, the SSO generally provides no guidance for what terms will be acceptable. ${ }^{84}$ It is also not always clear from the language of the IPR policy if the policy covers: (1) core essential and noncore essential patents; (2) only core essential patents; or (3) both types of technologically essential patents as well as commercially essential patents. Even if the policy specifically enumerates commercial essentiality, parsing the language will likely be necessary to determine

82. Int'L ELECTROTEChNiCAL COMM'N ET AL., supra note 40, at 5.

83. See, e.g., Audio Video Coding Standard Workgroup of China, Intellectual Property Rights POLICY ch. IV, art. 12 (2008), available at http://www.avs.org.cn/en/ (click on "IPR Policy").

84. Part of the reason that SSOs do not specify what FRAND means may be that SSOs want to avoid any appearance that their organizations exist for price-fixing purposes that would be illegal under antitrust law. Layne-Farrar et al., supra note 42, at 678-79. 
whether the IPR policy refers to broad, intermediate, or narrow commercial essentiality.

Standards are very important in industries with large network effects. When a standard is widely adopted, small companies can compete with large companies on a national level, or even a global level, by innovating and creating a new technology that is nonetheless interoperable with technologies already broadly accepted and used by the public. ${ }^{85}$ Interoperability can aid in the adoption of the new technology by easing the transition from the old to the new. Thus, standards can be used to support a competitive environment, but misuse of SEPs can interfere with this goal. Ideally, SSOs would effectively address potential problems in the standard-setting process ex ante, and parties that own SEPs could be trusted to not take advantage of standards to demand higher royalties from competitors than the individual patents would warrant on their own. The patent litigation of the last few years, however, suggests that this may be an area in need of policy oversight. ${ }^{86}$

\section{E. Highlighting FRAND Problems-A Hypothetical}

There are several major problems with patents and standards that will become more visible in the near future, and there is a dire need to determine the optimal legal theories to use in resolving these problems. To illustrate the issues, consider the following hypothetical situation. A chart depicting the relationships between parties and patents follows the hypothetical.

85. See Microsoft Corp. v. Motorola, Inc., No. C10-1823JLR, 2013 WL 2111217, at *5 (W.D. Wash. Apr. 25, 2013) ("SSOs seek to promote widespread adoption of their standards because the interoperability benefits of standards depend on broad implementation.").

86. See infra Part II. 


\section{FRAND COMMITMENTS IN THE WIDGET WORLD}

The Widget is a technology that is growing in popularity because of its ability to help people communicate. However, there are many ways to make a Widget. Widgets can be designed in a number of sizes, or using a number of different technologies. Widgetech makes one Widget that relies on combining a five-inch Widget-1A with a Widget-2C that transmits data at a frequency of $120 \mathrm{MHz}$. It currently licenses the patent for the five-inch Widget-1A from Gizmo, Inc. and holds the patent for the Widget-2C used in its Widget. Widgecom makes another Widget that relies on combining a three-inch Widget-1D with a Widget-2B that transmits information at a frequency of $20 \mathrm{MHz}$. Widgecom licenses the patent for the three-inch Widget-1D from G-Tech Corp. and the patent for the Widget-2B from HF Gadget, Inc.

It has become obvious that the Widget technology has the potential to be very beneficial for consumers, but currently, customers of Widgetech cannot change to Widgecom's service, and vice versa, because the two Widget technologies are too different. Because Widget technologies are not uniform, most people have elected to instead continue using Wadgets, an older technology that does not work as well or have as many features as the Widget, although the Wadget does allow content to be broadcast to a television. The Widget industry forms an SSO with the intent of developing a standard for Widget technology. Widgetech, Gizmo, G-Tech, and HF Gadget are all members of this SSO. Widgecom, however, does not join the SSO. The Widget SSO focuses on the current specifications used by Widgetech and Widgecom to determine what the standard should be, and thus has four different options for a Widget specification.

\begin{tabular}{|c|c|}
\hline Widget-1A and Widget-2C & Widget-1A and Widget-2B \\
\hline Widget-1D and Widget-2B & Widget-1D and Widget-2C \\
\hline
\end{tabular}

After evaluating the different options for Widgets, the five-inch Widget-1A and a $20 \mathrm{MHz}$ Widget-2B are eventually adopted as essential elements of the Widget standard, and Gizmo and HF Gadget both disclose to the SSO that they have patents on these respective technologies. The Widget SSO also addresses the possibility that consumers may want to use the Widget to broadcast to their televisions, so the organization notes that if a Widget producer wishes to make its Widget compatible with this purpose, the producer should use the Widget-3 technology, which is covered by a patent owned by Doodad LLC. Gizmo's Widget-1A and HF Gadget's Widget2B are both core essential patents for the Widget, and the Widget-3 is a noncore essential patent. Doodad LLC is not a member of the Widget SSO, but it is a member of the Wadget SSO, which adopted their Widget-3 patent as a core essential patent.

Upon the SSO's request, all of the SSO members (including Gizmo; G-Tech; and HF Gadget) sign an agreement with the SSO promising to license their relevant patents on FRAND terms to parties that wish to adopt the standard. Shortly after the standard has been finalized, Gizmo buys Doodad LLC's patent portfolio, and HF Gadget sells its patent portfolio to PatBuy, Inc. PatBuy is a patent assertion entity that relies on patent royalties for most of its revenue.

A year after the standard has been set, the market for Widgets has grown, and consumers are almost universally demanding that Widgets include the capability of 
broadcasting content to televisions, thus retaining one of the benefits of the Wadget. The Widget-3 patent, while initially a noncore essential patent, may also now be a commercially essential patent under the narrow definition thereof, even though it was not commercially essential when the standard was announced.

Though none of its technologies were included in the standard, G-Tech has entered the standard-compliant Widget market, having licensed the Widget-1 A and Widget2B included in the standard. In addition, the G-Tech Widget also includes a patented technology that it calls Widget-4, whereby the product is activated by waving the Widget in the air with a clockwise circular motion and turned off by waving it in the air with a counterclockwise circular motion. The motion-sensing activation mode has proven so popular with consumers that every Widget owner wants to own a Widget with Widget- 4 capabilities, and some market research indicates that $95 \%$ of current Widget consumers will not make a future purchase of a Widget if the Widget does not have Widget-4.

After spending the better part of last year making their Widget production capable of producing Widgets that adhere to the new standard, Widgecom and Widgetech start to produce standard-complying Widgets. When the standard was announced, Widgecom sent a letter requesting a license for the Widget-1A patent to Gizmo, and a letter indicating an intent to continue licensing the Widget-2B patent to HF Gadget. Similarly, Widgetech sent a letter to Gizmo indicating an intent to continue licensing the Widget-1A patent, and a letter to HF Gadget requesting a license to practice its Widget-2B patent. Widgetech also decides that it wants to include a feature in its Widget to allow broadcasting to televisions, so it sends a letter to Doodad LLC to request a license for the Widget-3 patent. Additionally, Widgetech adds Widget-4 capability to its Widget, and sends a letter to G-Tech to request a license.

Widgecom's attempt to license from Gizmo reaches a stalemate, and an acceptable royalty payment cannot be determined. Widgetech and Widgecom receive a letter from HF Gadget stating that they no longer hold the Widget-2B patent, but the letter does not say who the patent was assigned to. Widgetech receives a similar letter from Doodad LLC concerning the Widget-3 patent. G-Tech responds to Widgetech's request with a cease and desist letter, threatening litigation if Widgetech infringes the Widget-4 patent.

Gizmo sues Widgecom for infringing its Widget-1A patent and sues Widgetech for infringing its Widget-3 patent. Gizmo is seeking an injunction to prevent Widgetech and Widgecom from using these patents in their products.

PatBuy sues Widgetech and Widgecom for infringing its Widget-2B patent and is seeking a very high royalty of $20 \%$ of the sale price of each unit sold that infringes the claims of the Widget-2B patent. Widgecom produces proof of its existing license of the Widget-2B patent, and the court quickly dismisses PatBuy's claim based on wellestablished law that preexisting licenses are binding against subsequent patent owners.

G-Tech sues Widgetech for infringing its Widget-4 patent and seeks an injunction against sales of Widgetech products that include Widget-4.

Widgetech and Widgecom both argue that even in cases where a license did not already exist, all of the patent owners are obligated to license these patents on FRAND terms, and thus the court should assist the parties in setting the terms of the license agreements. 
The issues in this hypothetical can be visualized using the chart shown below.

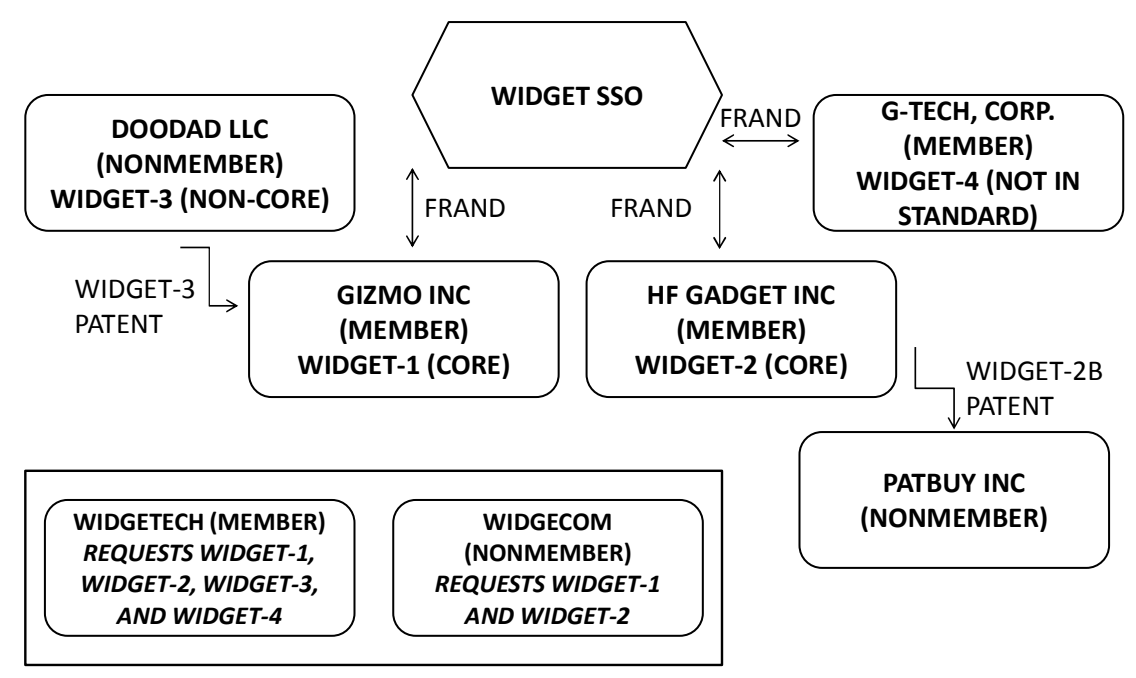

Figure 1. Widget SSO Hypothetical

This hypothetical illustrates several problems. A court evaluating the following problems is likely to first refer to the IPR policy of the Widget SSO. For our purposes, assume that the Widget SSO's IPR policy requires FRAND commitments and the disclosure of SEPs, but is vague about essentiality.

(1) Application to Nonmembers. Widgecom is not a member of the Widget SSO. Gizmo asserts that when it made its FRAND promise to the SSO, this promise only applied to SSO members. Can Widgecom benefit from the promise and obtain a license for the Widget-1A even though it is not a member of the Widget SSO?

(2) Widget-3, Essentiality and After-Acquired Patents. The Widget-3 patent is now held by Gizmo, but it was acquired after Gizmo made the FRAND promise to license its patents. This situation contains two distinct problems with their own complications. At their cores, these two problems focus respectively on whether the FRAND commitment applies to a particular patent, and whether the FRAND commitment applies to a particular patent holder.

(a) The first problem concerns the Widget-3 patent's status as a noncore essential patent that now may also be commercially essential, and this problem contains three parts.

(i) First, the parties will need to look at the IPR policy of the Widget SSO to determine whether noncore essential patents are considered SEPs. If the answer is yes, the FRAND commitment will apply to this patent, and the analysis for this problem ends here.

(ii) If the above answer is no, the parties then ask whether the Widget SSO considers commercially essential patents to be SEPs. If that answer is no, the analysis ends and the FRAND commitment does not apply to this patent.

(iii) But if the answer to the second subpart is yes, that introduces the problem of a noncore essential patent becoming commercially essential. The parties will then need to analyze the Widget SSO's IPR policy to determine the frame of 
reference for time - that is, does the IPR policy state that FRAND commitments apply to patents that were essential at the time the standard was published?

(b) The second problem focuses on whether the particular patent holder is bound by the FRAND commitment. This problem concerns the Widget 3 patent's status as an after-acquired patent, which Gizmo acquired only after making the initial FRAND commitment. As a company that made a FRAND commitment to license Widget patents, is Gizmo bound by this agreement such that it has to license the Widget-3 patent on FRAND terms?

(3) Broad View of Commercial Essentiality. G-Tech is a member of the SSO and made a FRAND promise, but G-Tech's Widget-4 patent was not included in the standard. However, the demand for Widget-4 capability is now very high. Should the FRAND commitment also apply to the Widget-4 patent such that G-Tech must license the patent on FRAND terms to Widgetech?

(4) Transferability of FRAND commitment. PatBuy was not a member of the SSO, and did not make any FRAND promises. Does the FRAND commitment made by HF Gadget also bind PatBuy and limit the royalties that PatBuy can seek for the Widget-2B patent?

(5) Remedies for Patent Infringement. Gizmo owns the Widget-1A patent, which is a core essential patent, and the Widget-3 patent, which is a noncore essential patent that may also be commercially essential. PatBuy owns the Widget2B, a core essential patent.

(a) Is it consistent with Gizmo's FRAND obligations to seek an injunction preventing nonmember Widgecom from using the Widget-1A patent? What about the Widget-3 patent? Is Gizmo's request for an injunction to keep SSO member Widgetech from using the Widget-3 patent consistent with Gizmo's possible FRAND obligations?

(b) Assuming that the FRAND obligations associated with the Widget-2B patent "ran with the patent" and bound PatBuy as a successor in interest, the court will have to determine whether a demanded royalty of $20 \%$ of the sale price for each unit sold is "fair and reasonable." This is fairly unlikely, but in the absence of a royalty agreement between the parties, the burden may be on the court to determine a royalty amount that would be consistent with PatBuy's FRAND obligations.

A final policy matter illustrated in this hypothetical that deserves a brief mention is transparency - that is, whether and to what extent recordation of assignments should be required. If patent transfers were required to be recorded with the USPTO, the above assignments to Gizmo and PatBuy might have been easier to track down. If the assignees had been easier to track down, the party seeking a license could have made a formal, prompt licensing request. Instead, Widgetech and Widgecom pushed forward with production of standard-compliant products to remain competitive, with the danger of patent litigation looming overhead, relying only on the earlier FRAND commitment to assure them that a license would be made available. Most of the above issues could be addressed through government intervention or through voluntary collaboration by SSOs, but it would likely be unreasonable to expect an SSO to keep track of patent transfers. Thus a transparency solution would likely require government intervention and would not have a corresponding private market solution. 


\section{Transparency}

The recordation of patent transfers already exists in some form in U.S. patent law, which currently allows patent assignments to take priority over subsequent transfers of the patent, but only if the patent assignment was recorded ${ }^{87}$ However, this provision does not make recordation mandatory. On the other hand, Executive Order 9424, which was issued on February 18, 1944, ${ }^{88}$ does make recordation mandatory, but only for interests in patents held by government entities. ${ }^{89}$

Some prominent policy actors, including academics,${ }^{90}$ the FTC, and the USPTO, have expressed support for requiring recordation of patent assignments. The FTC, in a 2011 report on patent law issues, asserted that accurate patent assignment records would assist parties in clearing patent rights. ${ }^{91}$ In November 2011, the USPTO published a request for comments (RFC) concerning a possible rule change to make assignment recordation mandatory. ${ }^{92}$ Like the FTC, the USPTO also noted that uncertain patent ownership has the potential to complicate patent clearance and interfere with market efficiency. ${ }^{93}$ These justifications for transparency are especially relevant in the standards context, where incomplete information can lead to very costly harm.

If the USPTO implements regulations to require the recordation of assignments, this could benefit parties, like Widgecom and Widgetech in the above hypothetical, who could more easily identify the new owners of the patents that they sought to license. However, to be useful, such regulations must balance concerns about costs and timing. As indicated by several comments in response to the RFC, the issue of costs is controversial because many fear that a recordation requirement would increase the costs associated with patent ownership. ${ }^{94}$

The added cost of recordation should be weighed against the need for recordation to be timely. If the patent assignments to Gizmo Inc. and PatBuy went unrecorded for five years, Widgecom and Widgetech would not be benefited by the recordation requirement, because they needed that information less than a year after the transfer. We recommend that in the case of SEP transfers, prompt recordation of assignments should be required, perhaps within ninety days of an assignment. A

87. 35 U.S.C. $\$ 261(2006)$.

88. Exec. Order No. 9424, 9 Fed. Reg. 1959 (Feb. 18, 1944).

89. 37 C.F.R. § 3.11(b) (2012).

90. E.g., Colleen Chien, Comment to the USPTO: Recordation of Real-Party-in-Interest Information (Jan. 25, 2013), http://www.uspto.gov/patents/law/comments/rpii-f_chien _130125.pdf.

91. FTC, supra note 8, at 131 ("Recording assignments of government-conferred rights to exclude is necessary to ensure public notice and will not unduly burden patent transfers.").

92. Request for Comments on Eliciting More Complete Patent Assignment Information, 76 Fed. Reg. 72372 (Nov. 23, 2011).

93. See id.

94. E.g., Intellectual Prop. Owners Ass'n's Response to the USPTO "Request for Comments on Eliciting More Complete Patent Assignment Information” (Jan. 23, 2012), http://www.uspto.gov/patents/law/comments/a_ipo_120123.pdf (pointing out that in the case of some organizations, patent prosecution and patent ownership issues may be handled by two separate departments, or perhaps even by two entirely separate sets of outside counsel). 
ninety-day deadline would be consistent with the current structure of $\S 261$, which allows an earlier assignment to take priority when it is recorded within three months. ${ }^{95}$ This kind of recordation requirement for SEP transfers is what Merrill and Smith would refer to as a "notice strategy," in that it provides a method to facilitate the disclosure of new information. ${ }^{96}$ Notice strategies are typically associated with rights in rem, a topic that we examine in more detail as it relates to SEPs in Part III.A.2.

\section{F. SSOs and IPR Policies}

In the hypothetical above, we intentionally omitted a detailed discussion of the Widget SSO's IPR policy. This is because the IPR policies of SSOs often vary significantly. An SSO might, for example, require members to add their patent to the "patent pool," which the SSO may then license to standard implementers as a package deal. ${ }^{97}$ In contrast, an SSO that emphasizes FRAND commitments typically leaves it to the patent owner and potential licensee to determine license terms.

The first major aspect of an SSO's IPR policy is the approach that the SSO takes to licensing obligations. Merges and Kuhn suggest that if the patent owner takes on an obligation, it is in the public interest to make that promise binding. ${ }^{98} \mathrm{We}$ assume, as a baseline, that courts will generally conclude that patent owners are bound by the obligations that they accept in IPR policies.

For our purposes, there are three main options for these obligations: (1) the SSO might request that members grant FRAND licenses; (2) the SSO might establish a patent pool to which members can contribute; or (3) the SSO might require patents to be licensed on royalty-free terms. The effectiveness of each of these three options is influenced by the industries and the business models of the participants. Devlin warns that FRAND-RF agreements could potentially lead to reduced innovation in some circumstances. ${ }^{99}$

Patent pools are often discussed as an alternative to an SSO model, ${ }^{100}$ though some SSOs also include a patent pool licensing option. For example, the IPR policy of China's Audio and Video Coding Standard (AVS) Workgroup allows members of the subgroup developing a standard to select between these three types of licensing obligations (FRAND, FRAND-RF, or participation in the patent pool). ${ }^{101}$

95. 35 U.S.C. $\S 261(2006)$.

96. Thomas W. Merrill \& Henry E. Smith, The Property/Contract Interface, 101 Colum. L. Rev. 773, 805 (2001).

97. Merges \& Kuhn, supra note 30, at 7. But see Lemley, supra note 19, at 1951 (considering SSOs to be similar to patent pools, but not the same).

98. Merges \& Kuhn, supra note 30, at 23.

99. See Alan Devlin, Standard-Setting and the Failure of Price Competition, 65 N.Y.U. ANN. SuRV. AM. L. 217, 227 (2009) ("But an SSO's insistence on royalty-free licensing may be undesirable with respect to technological innovation in the long run if other forms of compensation to the patentee are not forthcoming.").

100. Jorge L. Contreras, Fixing FRAND: A Pseudo-Pool Approach to Standards-Based Patent Licensing (Feb. 13, 2013) (unpublished working paper) ( on file with authors).

101. See Audio Video Coding Standard Workgroup of China, supra note 83, at 5-6. 
Under the AVS policy, if a member is not a part of the relevant subgroup when the standard is adopted, the member has a fourth option in addition to the above three options: to not take on any licensing obligation. ${ }^{102}$ Contreras proposes a "pseudopool" arrangement to mix the benefits of patent pools with the benefits of SSOs, ${ }^{103}$ but a true hybrid system as he proposes has not yet been adopted. Even in the case of SSOs like AVS, patent owners currently have to choose between FRAND commitments and patent pools. ${ }^{104}$

SSOs that emphasize FRAND licensing vary among themselves as well. Most limit the policy to technologically essential patents, while others allow the FRAND commitment to apply to commercially essential patents. ${ }^{105}$ Additionally, some SSOs use broad language to describe the parties that are entitled to FRAND licenses, while others do not address FRAND commitment beneficiaries. ${ }^{106}$

To get a sense of the variation, Lemley analyzed the intellectual property policies of over forty standard-setting bodies. ${ }^{107}$ Lemley categorized the SSOs according to: (1) whether the SSO had an IPR policy, and if so, what forms of IP were covered; (2) whether the SSO's policy required disclosure of relevant patents; (3) whether the IPR policy addresses an obligation to search for relevant patents; (4) whether the SSO would permit the final standard to rely on proprietary technology (most said yes, though some qualified that technologies covered by IP rights would only be included if technologically necessary); and (5) what licensing provisions the IPR policies contained (e.g., FRAND-RF or FRAND). ${ }^{108}$

Lemley's data indicate that the IPR policies of SSOs vary significantly. ${ }^{109}$ One of the elements that a majority of the studied policies had was a disclosure rule, with twenty-four of thirty-six policies requiring members to disclose relevant IP rights. ${ }^{110}$ Layne-Farrar, Padilla, and Schmalensee note, however, that some firms view disclosure requirements as potentially harmful, insofar as disclosing patents might reveal future technology strategies to competitors. ${ }^{111}$

Lemley's conclusions also underscore what he sees as an important function of SSOs and their IPR policies: providing private ordering to mitigate negative effects that IP rights seem to have on innovation in some industries. ${ }^{112}$ Lemley's empirical

102. Id. at 6 .

103. See generally Contreras, supra note 100 (suggesting that a pseudo-pool model could remedy the uncertainty of FRAND commitments).

104. Audio Video Coding Standard Workgroup of China, supra note 83.

105. Compare European Telecomms. StAndards InSt., supra note 54, at 41, with InST. OF ElEC. AND ELECS. ENG'RS STANDARDS ASS'N, supra note 73, § 6.1 (including commercial essentiality).

106. Compare Audio Video Coding Standard Workgroup of China, supra note 83, at 8 (defining "Licensees" as including "all Members and their Affiliates and all third party implementers of Compliant Portions"), with European Telecomms. Standards Inst., supra note 54 (not discussing the beneficiary of the FRAND commitment).

107. Lemley, supra note 19.

108. Id. at 1903 .

109. Id. at 1891.

110. Id. at 1904.

111. Layne-Farrar et al., supra note 42 , at 677-78.

112. Lemley, supra note 19, at 1971-72 (citing previous work indicating that patents can block improvements in the ICT industries). However, Lemley also says that IP rules must be 
work lays an important foundation for the study of the standard-setting process. However, his work did not examine all of the facets of possible IPR policies, and a future study might aim at updating and expanding on Lemley's findings from his 2002 study. For example, future research might evaluate: (1) the different approaches of SSOs to patent transfers; (2) whether the licensing provisions apply equally to members and nonmembers of the SSO; (3) whether the IPR policies define essentiality; (4) whether the IPR policies address after-acquired patents; and (5) whether the IPR policies attempt to limit remedies that patent owners can seek in litigation over SEPs.

In preparing this Article, we conducted a cursory overview of a small sample of IPR policies (IEEE-SA, ITU-T, ETSI, and AVS) to get a sense of whether Lemley's conclusions about nonuniformity are still valid over ten years later. Based on our initial observations, we posit that Lemley's observations in 2002 are also applicable to SSOs in 2013, where nonuniformity continues to be the unspoken rule. We noted that SSOs generally give members wide leeway in management of their own IP. IEEE-SA, for example, requires members to submit "Letters of Assurance" indicating if the member owns any "Essential Patent Claims," but explicitly states that the policy does not create a duty to conduct a patent search. ${ }^{113}$ Many SSOs also indicate a preference that patents be transferred subject to FRAND commitments, ${ }^{114}$ but SSOs also typically have a policy against getting involved in licensing matters. ${ }^{115}$ Thus, even if the IPR policies of SSOs were made more uniform, SSOs themselves generally do not provide an effective enforcement mechanism for these policies. Because the transferability of FRAND commitments is a cornerstone of this Article, we turn now to a more detailed discussion of the approaches that four SSOs take to this question.

\section{IPR Policies and Patent Transfers}

If an SSO specifically addresses transfers in its IPR policy, by agreeing to be bound by the terms of the SSO's IPR policy, the member is agreeing to be bound by the SSO's requirements for the transfer of intellectual property and FRAND commitments. To have any real force, however, IPR policies requiring patents to be transferred subject to FRAND commitments must either be combined with the property-based approach that we propose in Part III, or provide for harsh outcomes sufficient to deter the member from transferring the patent without obtaining the assignee's consent to be bound by the FRAND commitment. We view IEEE-SA's approach as a precursor to a full property-based approach to FRAND commitment transferability, because IEEE-SA notes that members should provide assignees

transparent and fair to fulfill this function. Id. at 1957.

113. Inst. OF EleC. \& EleCs. ENG'RS StANDARDS Ass'N, supra note 73, § 6.

114. See, e.g., id. (requiring members to transfer patents subject to the FRAND commitment).

115. See, e.g., Common Patent Policy for ITU-T/ITU-R/ISO/IEC, INT'L TELECOMM. UNION (2013), http://www.itu.int/en/ITU-T/ipr/Pages/policy.aspx ("The detailed arrangements arising from patents (licensing, royalties, etc.) are left to the parties concerned, as these arrangements might differ from case to case."). 
with a "Statement of Encumbrance" that states that the patent is being transferred subject to existing encumbrances, including accepted "Letters of Assurance."116

In preparing this Article, we reviewed the IP policies of several SSOs, with an eye to getting an introductory understanding of the different approaches these SSOs take with regard to the transfer of patents covered by the standard. Even looking at just four IPR policies (IEEE-SA, ITU, AVS, and ETSI), we saw a variety of approaches to the issue of transferring essential patents. For instance, the approaches varied as to whether the transfer has to be subject to the same FRAND commitment or whether the SSO merely expresses a preference that the transfer be made subject to the same FRAND commitment.

On this point, ITU and ETSI both require the member executing a transfer to notify the assignee of the relevant obligation. ${ }^{117}$ ITU also requires that the member who reasonably believes he is bound by a FRAND commitment as to the patents he is assigning must make "reasonable efforts" to obtain the assignee's agreement to be bound by the FRAND commitment. ${ }^{118}$ However, if the member fails to obtain such an agreement upon making reasonable efforts, the ITU member will have no further express obligations with regard to the licensing commitment and the transfer. ${ }^{119}$ The ETSI policy also addresses an inability to obtain a FRAND commitment. Under section 8 of the ETSI policy, however, if an essential patent becomes unavailable after the standard is finalized, the burden is on ETSI to seek a commitment from the patent owner to license on FRAND terms, and a failure to obtain such a commitment could even lead to ETSI scrapping the entire standard. ${ }^{120}$ On the other hand, both IEEE-SA and AVS require the patent owner to secure the assignee's agreement to be bound, rather than merely requiring the patent owner to make "reasonable efforts" to do so. ${ }^{121}$

These four SSOs thus represent three distinct approaches to transfers in an SSO's IPR policy: (1) a statement of the SSO's preference for transferability without imposing concrete obligations; (2) a requirement imposing some responsibility for obtaining FRAND commitments from new assignees on the SSO itself; and (3) a provision consisting of explicit language that transfers must be made subject to the FRAND commitment. Analysis of a larger sample might reveal

116. Inst. OF ElEC. AND ElECS. ENG'RS STANDARDS Ass'N, supra note 73, § 6.

117. Intellectual Property Rights, InT'L Telecomm. Union (Oct. 26, 2012), http://www.itu.int/en/ITU-T/ipr/Pages/default.aspx; Intellectual Property Rights (IPRs) in ETSI, EuROPEAN TELECOMMS. STANDARDS INST. (2012), http://www.etsi.org/about/iprs-in-etsi.

118. INT'L ELECTROTECHNICAL COMM'N ET AL., supra note 40, at 5.

119. See id. Section 7 of the IPR policy of the ITU, however, does specify that if the member had specifically identified patents to the standard-setting body, the member would be required to obtain the assignee's consent to be bound by the same agreement as the member. $I d$.

120. European Telecomms. Standards Inst., supra note 54, at 37-38. The approach taken by ETSI, where the SSO reserves a right to scrap the entire standard if a FRAND commitment cannot be obtained, is mostly unique because it is explicitly stated. Some indications suggest that this approach is fairly common in the standard-setting context, but many SSOs do not expressly refer to it in their IPR policies.

121. See Inst. of Elec. \& Elecs. Eng'Rs Standards Ass'n, supra note 73, § 6; Audio Video CODING STANDARd Workgroup OF China, supra note 83. 
even more options. The fact that we found three different approaches to transfers in four SSOs, however, supports Lemley's conclusions about nonuniformity in SSOs' IPR policies and suggests that this nonuniformity is pervasive throughout IPR policies and is not limited to the categories that Lemley examined.

Ultimately, we urge that SSOs should amend their IPR policies to address the issues that we raise in this Article. Further analysis may be beneficial to determine whether these IPR policy changes should be prospective or retrospective. Requiring the new IPR policy to only bind future standards might be easier to handle under traditional contract law, because otherwise new consideration might be required to bind parties to the amended policy. ${ }^{122}$ On the other hand, if the same SSO develops two standards that often are used in the same device, but one standard is governed by the pre-amendment IPR policy and one standard is governed by an amended IPR policy, the same lack of uniformity that is currently a problem between SSOs would actually exist within the same SSO.

Uniformity among the approaches of different SSOs could also be beneficial, and this uniformity could be achieved through a voluntary consortium or through government intervention and oversight. As discussed below in Part II.B.3, formal contract law would likely be adequate for addressing issues relating to nonmembers, after-acquired patents, and essentiality, provided the IPR policy contained sufficient detail on these topics. However, contract law alone will not cause FRAND commitments to be binding on assignees in the absence of the assignee giving explicit consent to be bound.

As the above discussion demonstrates, there are many issues that may arise when SSOs adopt standards that rely on patented technologies. The IPR policies of SSOs may attempt to address some of these issues ex ante, but SSOs are generally unable to exercise any control over the transfers of patents owned by members if the SSOs do not impose explicit terms to that effect. The law also appears to keep a largely "hands-off" approach with respect to patent assignments, deferring to the patent owners to make private deals with minimal oversight. This approach may be a positive attribute of the IP system in most contexts, but when SEPs are in issue, some additional oversight could be beneficial to ensure that patent owners also take the public interest into account. We turn now to the main category of legal oversight that has been thus far utilized in the context of standards issues: civil litigation resulting from a dispute.

\section{STANDARDS, LITIGATION, AND LEGAL THEORIES}

Due to the complexity of standards and IPR policies, there are many opportunities for companies to engage in unfair or inefficient behavior. In the interest of inclusiveness, we have decided to eschew the terms "patent holdup" and "patent ambush" in this Part. Each term is informative and descriptive, but the problems that arise in the standard-setting context may justify new terminology. "Patent holdup," for example, is a phrase that describes the effect of an action, but

122. See, e.g., Glisson v. Global Sec. Servs., LLC, 653 S.E.2d 85, 87 (Ga. Ct. App. 2007) (finding that continued employment was not sufficient consideration to make a noncompete agreement an enforceable contract). 
not the action itself. On the other hand, "patent ambush" implies a degree of premeditation that may not exist when the ambushing patent was recently transferred from a FRAND-complying assignor to a FRAND-denying assignee. The patent misuse problems that are associated with the standard-setting process are also likely to be narrower than the implications of either of these terms.

In our view, there are three main situations in which a patent holder may unfairly leverage his patent in the standard-setting context: (1) a patent may be concealed during the standard-setting process ("concealment"); (2) a patent holder may change his mind after making a FRAND commitment or otherwise seek arguably non-FRAND terms ("bait-and-switch"); ${ }^{123}$ and (3) a patent holder who made a FRAND commitment may transfer the patent to a third party that refuses to honor the FRAND commitment ("succession").

The first situation, concealment, may arise when a party has a patent that is essential to a standard under development, but intentionally fails to disclose this patent to the SSO. Once the standard has been adopted, this patent holder might sue good faith adopters of the standard for infringement. Concealment could be considered a specific type of patent ambush that is made possible because of the relationship between the patent owner and the SSO. Some SSOs address the problems raised by the threat of patent concealment by including provisions in their rules that require FRAND-RF licenses to be granted by patent owners that have intentionally concealed patents. ${ }^{124}$ If the patent holder would otherwise at least be entitled to a reasonable royalty for the use of the patent by standard adopters, a requirement that the patent holder license the patent on a royalty-free basis would be less appealing to a company that wants to earn revenue from its patents; thus, the IPR policy discourages concealment.

In the second situation, bait-and-switch, a party may disclose his patent to the SSO and initially agree to license the patent on FRAND terms to anyone who requests a license. The patent owner might then later change his mind or otherwise demand excessive royalties from competitors that want to implement the standard. This situation is problematic in part because the potential licensee may have already made substantial investments in reliance on the FRAND promise.

The third situation, where a patent is assigned to a successor in interest who did not make a FRAND commitment with the SSO, is less clear. The effect of patent transfers on the enforceability of FRAND commitments is currently an open question. The FRAND commitment is typically construed as a contract between the initial patent holder and the $\mathrm{SSO},{ }^{125}$ so the question arises of when and under what

123. Here, we are using the term "bait-and-switch" in much the same way that Merges and Kuhn use the term. In their 2009 article, Merges and Kuhn refer to two potential types of patent holdup: snake-in-the-grass and bait-and-switch. Merges \& Kuhn, supra note 30, at 10. Our category of "concealment" is similar to the Merges and Kuhn category of "snake-in-the -grass," but we used the term concealment because it is more in keeping with our theme of focusing on the actions rather than the effects.

124. See, e.g., VITA STANDARDS ORG., supra note 81, at 14 ("If a WG Member fails to adequately and timely disclose . . . a patent claim or license terms for it as set forth in this Section 10 . . . the VITA Member Company must license it to the extent it is essential to a Draft VSO Specification on a royalty free basis ....").

125. E.g., Research In Motion Ltd. v. Motorola, Inc., 644 F. Supp. 2d 788, 797 (N.D. 
circumstances a successor in interest can be bound by that contract and by whom. The approaches of SSOs vary on this point. Many state in their policies a preference that future assignees be bound by the FRAND commitment. ${ }^{126}$ However, some SSOs merely require the contracting party to make a reasonable effort to obtain the assignee's agreement to be bound, while others require that any assignment have the express condition of being subject to the FRAND commitment. ${ }^{127}$ SSOs also may vary on whether the agreement explicitly addresses granting licenses to nonmembers and whether the FRAND commitment applies to core essential, noncore essential, and commercially essential patents. ${ }^{128}$

\section{A. Litigation over FRAND Commitments}

Litigation over a FRAND commitment may come in several forms, which are most commonly focused on antitrust law or contract law. ${ }^{129}$ If the FRAND commitment creates a duty to negotiate in good faith, as some courts have suggested, ${ }^{130}$ the reality of negotiation introduces more complications. For example, in normal negotiations, if the party seeking a payment is the first to offer, it will often highball the other party, thus causing future negotiations to use that high initial offer as a reference point. ${ }^{131}$ Similarly, if the party that will be making a payment is the first to offer, it will often lowball the other party, and future negotiations may thus be anchored lower due to the lower initial reference point. ${ }^{132}$

But what about negotiations when there is a FRAND commitment? Both parties know that the end result has to be fair and reasonable. The district court in Microsoft Corp. v. Motorola, Inc. recently emphasized that an initial offer must be at least made in good faith. ${ }^{133}$ Additionally, some SSOs use language requiring that negotiations must be on FRAND terms, suggesting that the initial offer must also

Tex. 2008) (referring to the FRAND commitments made to IEEE and ETSI as contracts).

126. E.g., European Telecomms. Standards Inst., supra note 54, at 36 ("FRAND licensing undertakings made pursuant to Clause 6 shall be interpreted as encumbrances that bind all successors-in-interest.").

127. See supra Part I.F.1 for a brief discussion of four SSOs and their very different rules about the effect of patent transfer on FRAND commitments.

128. See, e.g., Inst. OF Elec. \& Elecs. Eng'Rs StAndards Ass'N, supra note 73 (permitting narrowly commercially essential patents to be considered SEPs and including patents that are essential to mandatory or optional portions of the standard); EUROPEAN Telecomms. Standards Inst., supra note 54, at 41 (defining "essential" as referring to patents that would be infringed by efforts to comply with a standard but explicitly excluding the concept of commercial essentiality).

129. E.g., Research In Motion, 644 F. Supp. 2d at 796-98 (examining antitrust and breach of contract claims).

130. E.g., Apple Inc. v. Samsung Elecs. Co., No. 11-CV-01846, 2012 WL 1672493, at *12 (N.D. Cal. May 14, 2012) ("Moreover, both parties agree that Samsung's contractual obligation arising from its FRAND declarations to ETSI at the very least created a duty to negotiate in good faith with Apple regarding FRAND terms.").

131. See Steven J. Pasternak, An Overview of the Development Process, 8 Sw. J.L. \& TRADE AM. 1, 19 (2001) (referring to different approaches taken by sellers and purchasers in negotiations).

132. See id.

133. 864 F. Supp. 2d 1023, 1038 (W.D. Wash. 2012). 
abide by FRAND principles. ${ }^{134}$ If the initial offer is required to be on FRAND terms, this may restrict the ability of negotiators to use either highballing or lowballing techniques.

When a patent owner has previously entered into a FRAND commitment, she may attempt to comply with this agreement at first and engage in negotiations with the potential licensee. However, if the negotiations are unsuccessful or not likely to be successful, the parties might file suit and request that a court intervene and set the FRAND terms. A court that is tasked with setting FRAND terms for a license may use a similar approach as when the court is asked to set a reasonable royalty or determine if a proffered royalty amount is reasonable. If a court is asked to determine if a royalty is reasonable, the court will often weigh a number of factors, possibly applying the fifteen-factor test of Georgia-Pacific. ${ }^{135}$ This can quickly become very complicated, as Judge Robart's recent 207-page decision in Microsoft v. Motorola indicates. ${ }^{136}$ In the FRAND context, a court that is asked to set a royalty amount will likely have to consider the increased value that a patent enjoys merely by being essential to a standard and may eventually set the royalties at the level that would be appropriate if the patent's value had not been inflated by its use in a standard. ${ }^{137}$

As is true with most litigation, FRAND litigation is rarely focused on a single issue. Litigation over a FRAND commitment may raise antitrust issues, with one or both parties asserting that the other is behaving in an anticompetitive manner and violating antitrust law. ${ }^{138}$ Even if the FRAND commitment portion of the dispute is governed by principles of contract law, the parties are likely to raise patent issues as well, including patent validity. ${ }^{139}$ Because of the importance of contract law, however, FRAND commitment claims may be brought in state court or federal district court, and appeals may be heard by many different courts other than the Federal Circuit, which handles appeals of patent cases.

If the case involves claims of patent infringement, the patent holder may also be seeking an injunction, a common remedy sought in patent cases. Under eBay Inc. v. MercExchange, $L L C,{ }^{140}$ a four-factor test for determining the appropriateness of an

134. See, e.g., Common Patent Policy for ITU-T/ITU-R/ISO/IEC, supra note 115. At least one court has read ITU's patent policy as applying the FRAND requirement at the negotiation stage. ESS Tech., Inc. v. PC-TEL, Inc., No. C-99-20292 RMW, 1999 WL 33520483 , at $* 4$ (N.D. Cal. Nov. 4, 1999).

135. Georgia-Pacific Corp. v. U.S. Plywood Corp., 318 F. Supp. 1116, 1120 (S.D.N.Y. 1970).

136. Microsoft Corp. v. Motorola Inc., No. C10-1823JLR, 2013 WL 2111217 (W.D. Wash. Apr. 25, 2013); see also Eingestellt von Florian Mueller, A Closer Look at the 207Page, Landmark FRAND Rate-Setting Decision in Microsoft v. Motorola, Foss PATENTS (Apr. 28, 2013, 11:49 PM), http://www.fosspatents.com/2013/04/a-closer-look-at-207-page -landmark.html.

137. See Apple, Inc. v. Motorola, Inc., 869 F. Supp. 2d 901, 913 (N.D. Ill. 2012) (referring to this situation as being one of the purposes of FRAND commitments).

138. E.g., Research In Motion Ltd. v. Motorola, Inc., 644 F. Supp. 2d 788 (N.D. Tex. 2008).

139. See, e.g., Apple, 869 F. Supp. 2d at 923 (ruling on requests for declaratory judgments of invalidity and infringement).

140. 547 U.S. 388 (2006). 
injunction applies to patent disputes. To obtain a permanent injunction under that test, a patent owner must demonstrate the following: (1) irreparable injury; (2) the inadequacy of money damages to compensate for the injury; (3) that a remedy in equity is warranted after considering the balance of hardships between the parties; and (4) that a permanent injunction would not be harmful to the public interest. ${ }^{141}$ Patent law inherently gives patent owners a right to exclude others from practicing their invention, ${ }^{142}$ so when a court determines that an injunction is not appropriate but that the nonowner was infringing the patent, the court may set an ongoing royalty rate; this resolution will provide reasonable compensation to a patentee who has effectively given up his right to exclude the infringer from practicing the patent. ${ }^{143}$ A study by Chien and Lemley found that there has been a reduction in injunctions since $e B a y$, but the authors suggest that this reduction may be offset by the continued availability of injunctions in litigation before the International Trade Court (ITC), ${ }^{144}$ an issue that we discuss in more detail in Part IV.C.

Bankruptcy is another area that these disputes occasionally implicate. Above, we noted that patents are often bought and sold. Sometimes, these purchases are not between two solvent companies, but instead occur when one of the companies is declaring bankruptcy and its patent portfolio is being sold to satisfy debts. ${ }^{145}$ Under the bankruptcy law of the United States, patents are generally treated as assets subject to sale by the trustee in the event that the patents are found to be nonexempt assets of the bankruptcy estate pursuant to the bankruptcy code. ${ }^{146}$ Merges and Kuhn note that the interests of a bankruptcy estate are often very different from the interests of the original patent owner, as the bankruptcy estate has a fiduciary duty to creditors, and thus the estate has the incentive to maximize short term profits. ${ }^{147}$ IP licenses are granted some protection, with licensees generally being given the power to elect to retain their rights. ${ }^{148}$

However, a FRAND commitment does not create an express license, though it arguably imposes on the patent owner a duty to negotiate in good faith; as such, the agreement's fate under a bankruptcy proceeding is unclear. Because of the importance of FRAND commitments to public interest concerns, one option is for bankruptcy courts to treat FRAND commitments in a way similar to nondischargeable priority debts. ${ }^{149}$ The court and the parties can also take action to clarify this issue. In the bankruptcy proceeding for Nortel Networks Inc., the bankruptcy court stated that debtors would take assets free of any other liens or

141. Id. at 391.

142. 35 U.S.C. $\S 271$ (2006) (setting out conditions for patent infringement).

143. Paice LLC v. Toyota Motor Corp., 609 F. Supp. 2d 620, 624 (E.D. Tex. 2009).

144. Chien \& Lemley, supra note 38, at 3-4 (warning that PAEs have started seeking exclusion orders from the ITC in greater numbers since eBay was decided in 2006).

145. See, e.g., In re Nortel Networks Inc., No. 09-10138(KG), 2011 WL 4831218 (Bankr. D. Del. July 11, 2011).

146. 11 U.S.C. $\S 363$ (2006 \& Supp. V 2011) (sale of assets by trustee); 11 U.S.C. $\S 522(\mathrm{~d})(5)$ (2006) (exemptions).

147. Merges \& Kuhn, supra note 30 , at 36.

148. 11 U.S.C. $§ 365(n)$ (2006).

149. See Merges \& Kuhn, supra note 30, at 37-38 (suggesting the adoption of a similar approach in the authors' proposed standards estoppel doctrine). 
interests, except for a few categories of interests. ${ }^{150}$ One of the enumerated categories that Nortel's debtors took assets subject to was enforceable agreements with SSOs. ${ }^{151}$ The Nortel example shows that bankruptcy courts are receptive to arguments regarding the value of FRAND commitments made to SSOs, and that these courts have the power to prevent these commitments from being discharged in bankruptcy.

Litigation over FRAND commitments is likely to involve many different legal areas and theories. Bankruptcy law may be implicated when the question is whether a FRAND commitment survives a bankruptcy proceeding, but this is likely to come up in a more narrow circumstance. Instead, much of the litigation in this context begins based on the patent owner's claim for infringement, so defenses under patent law may be relevant. Because the effects that patent exclusivity has on competition can be especially harsh when the patents are part of a standard, arguments may also assert that the patent owner engaged in unfair competition or anticompetitive behavior. Finally, at its core, a FRAND commitment is a contract, so contract law doctrines are likely to influence outcomes of litigation. Thus, we turn now to a more detailed evaluation of these three areas of law (patents, antitrust, and contracts), and how they currently affect some of the major problems that we argue arise in the context of FRAND commitments and patent transfers.

\section{B. The Law of FRAND Commitments and Transferability}

When a patent holder assigns her patent to a third party, and the patent was previously subject to a FRAND commitment with an SSO, is the third-party assignee bound by this agreement? This is a difficult question that current law inadequately addresses. Currently, the discussion of these topics mostly focuses on patent law, antitrust law, and contract law. ${ }^{152}$ Patent law offers the weakest options for addressing FRAND disputes. The options under antitrust are somewhat stronger than under patent law but are fundamentally limited by the current nature of antitrust law in the United States. In terms of the legal theories that have been examined for these purposes, contract law has the most potential for addressing the problems set forth in the above hypothetical, but it still has many shortcomings.

In this Part, we will discuss some of the current aspects of several areas of law, and then go into more detail in an attempt to conclude which theories, if any, are best suited to address the first four problems faced by the parties in our Widget hypothetical: (1) the transferability of FRAND commitments; (2) the enforcement of FRAND commitments by nonmembers of the SSO; (3) the application of FRAND commitments to "core" essential patents, "noncore" essential patents, and commercially essential patents; and (4) the application of FRAND commitments to after-acquired patents. The question of appropriate remedies is addressed separately in Part IV because these issues are most likely to be raised in the context of patent litigation, which historically has been associated with injunctions.

150. In re Nortel Networks, 2011 WL 4831218, at *9.

151. Id.

152. See Lemley, supra note 19, at 1909 (asserting that the IP rules of SSOs should be enforced through contract and IP law but acknowledging that there are issues that make it difficult to enforce the rules effectively through these means). 


\section{Patent Theory}

Some principles of patent law may be applicable to the current controversy, including laches, equitable estoppel, implied licenses, or a theory that allows the original patent owner's wrongdoings to be imputed to the successor in interest.

\section{a. Patent Law Cases}

Laches is a patent law doctrine that resembles a statute of limitations in that it prevents patent holders from profiting by their delay in bringing suit for infringement. ${ }^{153}$ A laches defense tends to follow the patent, and a patent assignee will be bound by the conduct of his predecessor in interest. ${ }^{154}$ When raising a defense of laches, the defendant must establish two things: (1) there was an unreasonable delay before the patent owner asserted a claim; and (2) the delay caused prejudice or injury to the defendant. ${ }^{155}$ The length of time necessary for a delay to be unreasonable varies with the situation, but a delay of six years or more is generally viewed as prima facie unreasonable. ${ }^{156}$ The prejudice prong may refer to economic prejudice or evidentiary prejudice. ${ }^{157}$ An inquiry concerning economic prejudice would focus on investments or damages that would not have accrued if the patent owner had brought suit sooner. ${ }^{158}$ An inquiry concerning evidentiary prejudice would focus on circumstances where the defendant's ability to present a full defense on the merits has been prejudiced due to factors like a witness's death or loss of records. ${ }^{159}$

However, laches depends on notice of specific infringement and typically requires there to be a communication between the owner and infringer about that infringement. ${ }^{160}$ In the standards context, a patent holder may not have specific notice of every implementation of the infringing standard. Thus, even if the patent holder decides to wait several years to track down and sue specific infringers, the clock for laches would probably not start running unless the patent holder has notice about a particular infringing incident and has contacted the infringers about the possibility of litigation. ${ }^{161}$ Additionally, courts typically do not find economic prejudice based on the cost of infringing, ${ }^{162}$ and Merges and Kuhn suggest that this indicates that courts may not be receptive to an argument that the delay in bringing

153. Merges \& Kuhn, supra note 30 , at 33-34.

154. Id. at 35 .

155. A.C. Aukerman Co. v. R.L. Chaides Constr. Co., 960 F.2d 1020, 1032 (Fed. Cir. 1992).

156. Id. at 1028; Merges \& Kuhn, supra note 30, at 44 .

157. A.C. Auckerman, 960 F.2d at 1033.

158. Id.

159. Id.

160. See id. at 1028 .

161. See Merges \& Kuhn, supra note 30, at 41-42 (noting that the "knew or should have known" requirement of laches does not protect the entire group of standards adopters).

162. E.g., Globe-Union, Inc. v. Tiegel Mfg. Co., 228 U.S.P.Q. 58, 60 (N.D. Cal. 1985) ("The mere fact that if plaintiff had sued defendant earlier, defendant would have stopped infringing does not constitute actual prejudice under the applicable case law."). 
suit deprived the standards adopter of the chance to find a noninfringing workaround. $^{163}$

A defense related to laches is equitable estoppel, which allows an accused infringer to claim that the patent owner's "course of conduct reasonably gave rise to an inference" that the patent would not be enforced. ${ }^{164}$ Equitable estoppel and laches are both defenses that focus on nonenforcement, but equitable estoppel focuses on the mindset of the potential licensee, rather than that of the patent owner. ${ }^{165}$ Where laches requires the patent owner to be aware of specific infringement and fail to take action, equitable estoppel requires, at a minimum, that the accused infringer is aware that the patent owner made statements addressing nonenforcement of the patent and that the accused infringer then relied on that statement. ${ }^{166}$ The Federal Circuit, in A.C. Aukerman Co. v. R.L. Chaides Construction Co., stated that reliance requires for the infringer to "have had a relationship or communication with the plaintiff which lulls the infringer into a sense of security."167 Lemley notes that equitable estoppel arguments may also apply to statements made in the marketplace or directly to customers. ${ }^{168}$ Merges and Kuhn observe that in limited situations, silence may also contribute to an equitable estoppel defense as a misrepresentation if there was a clear duty to speak. $^{169}$

In the SSO context, Lemley suggests that equitable estoppel should exist when the standard adopter is aware of a statement that the patent owner made to the SSO concerning enforcement of the patent. ${ }^{170}$ However, Lemley expresses doubt that equitable estoppel would protect standard adopters who rely on FRAND promises because the promise does not prompt a reliance on nonenforcement of the patent, but rather it elicits an expectation that the patent will be asserted and reasonable royalties sought. ${ }^{171}$ The affirmative communication requirement of equitable estoppel may also limit the FRAND commitment to only benefiting other members of the SSO to whom the FRAND commitment was made. ${ }^{172}$ Additionally, if the patent owner fails to disclose relevant patents, it is unclear whether this failed disclosure passes the high bar for silence to be deemed misrepresentation. ${ }^{173}$ Thus, a slightly amended approach to equitable estoppel might be needed to address repudiated FRAND commitments, allowing a standard adopter to estop a patent owner from denying a license or seeking an injunction, even if the patent owner

163. Merges \& Kuhn, supra note 30 , at 45-46.

164. Lemley, supra note 19, at 1918 (quoting A.C. Aukerman, 960 F.2d at 1028).

165. See A.C. Auckerman, 960 F.2d at 1028, 1043 (evaluating claims based on laches and equitable estoppel).

166. Id. at 1028-29, 1043-44.

167. Id. at 1043 .

168. Lemley, supra note 19, at 1921 .

169. Merges \& Kuhn, supra note 30 , at 39.

170. Lemley, supra note 19, at 1920-21.

171. Id. at 1923 .

172. Merges \& Kuhn, supra note 30 , at 23.

173. Compare id. at 39-40 (suggesting that misrepresentation might not be found in a failure to disclose), with Lemley, supra note 19, at 1918 (positing that nondisclosure of patents to an SSO might count as silence when there is a duty to speak). 
was not the party that initially made the commitment to the SSO. ${ }^{174}$ Under the approach proposed by Merges and Kuhn, the proposed affirmative defense of standards estoppel should also survive assignment of the patent. ${ }^{175}$

Case law about de facto standards suggests that courts may be receptive to arguments based on equitable estoppel. The idea that users of standards become reliant on the availability of the technology can be found in patent cases like Lotus Development Corp. v. Borland International, Inc. ${ }^{176}$ In Lotus, the reliance interest was effectively created in the user who devoted time to learning the spreadsheet application Lotus 1-2-3. ${ }^{177}$ The court acknowledged that Lotus 1-2-3 "represented the de facto standard for electronic spreadsheet commands," but concluded that if a better spreadsheet product became available, Lotus users should be able to apply their Lotus 1-2-3 knowledge and macros to the superior products instead of either learning a new system from scratch or being locked in to Lotus 1-2-3. ${ }^{178}$

Another patent law option that might assist standard adopters when a patent owner reneges on a FRAND commitment is the possibility of implied licenses. An implied license is a quasi-contract doctrine that turns on the expectations of the parties in a sales transaction. ${ }^{179}$ Merges and Kuhn note that the implied license issue may arise in the case of a patented process that requires the use of a nonpatented item. ${ }^{180}$ In such a situation, a court might say that the purchaser of the nonpatented good has an implied license to use the patented process that the purchaser acquired the nonpatented good to use. ${ }^{181}$ Lemley has argued that viewing a FRAND commitment as an implied license would allow all of the standard adopters to benefit, regardless of whether they would have had standing to sue for contract damages, and that such an approach would also reduce opportunism in litigation over SEPs. ${ }^{182}$ However, Merges and Kuhn argue that such implied licenses would probably be construed very narrowly, and thus would not be likely to provide an effective remedy. ${ }^{183}$

We have not located any FRAND-specific cases that emphasize an implied license theory, but implied licenses are an accepted possibility in patent law. ${ }^{184}$ However, the cases addressing implied licenses generally focus on contexts where there is a relationship between the patent owner and the party claiming an implied license. For example, in Wang Laboratories, Inc. v. Mitsubishi Electronics

174. Merges and Kuhn suggest an alternative that they call "standards estoppel." Merges \& Kuhn, supra note 30 , at 20.

175. Id. at 34 .

176. 49 F.3d 807 (1st Cir. 1995).

177. Id. at 819-21 (Boudin, J., concurring).

178. Id. at 821; see also Merges \& Kuhn, supra note 30, at 20 (discussing the Lotus case).

179. Lemley, supra note 19, at 1923-24.

180. Merges \& Kuhn, supra note 30 , at 35.

181. Lemley, supra note 19, at 1924 (citing United States v. Univis Lens Co., 316 U.S. 241 (1942)).

182. Id. at 1925 .

183. Merges \& Kuhn, supra note 30 , at 35.

184. See, e.g., Wang Labs., Inc. v. Mitsubishi Elecs. Am., Inc., 103 F.3d 1571, 1580 (Fed. Cir. 1997). 
America, Inc., the Federal Circuit found an implied license where Wang had entered into an agreement with Mitsubishi to manufacture (and then sell back to Wang) SIMM cards that Wang had developed. ${ }^{185}$ Wang did not inform either Mitsubishi or the SSO that it was seeking a patent on the SIMM technology. ${ }^{186}$ Lemley has suggested that the implied license doctrine may assist in resolving disputes over FRAND commitments, arguing that the FRAND commitment creates an implied license under proper circumstances, ${ }^{187}$ but it is currently unclear how courts would respond to this argument.

The final approach that we noted under patent law, imputing the wrongdoings of a predecessor in interest, is likely insufficient to address most of the disputes that would arise in the context of transferring patents subject to a FRAND commitment, but is worth noting. If the previous owner of the patent made an intentional fraudulent representation to the SSO or to the USPTO, that misrepresentation could potentially lead to the patent being ruled unenforceable because of the inequitable conduct. ${ }^{188}$ In Barnes \& Noble, Inc. v. LSI Corp., the court allowed such a claim to proceed where the claim was based on an assertion that LSI's predecessor in interest (Lucent) "intentionally and knowingly made material misrepresentations and/or omissions in connection with standards-setting organizations." ${ }^{, 189}$ The court in Barnes \& Noble also noted that fraud, both prior and subsequent to patent issuance, can make a patent unenforceable. ${ }^{190}$ This theory may thus be an option for standard adopters if the potential licensee can establish that the patent was transferred for the purpose of avoiding the obligations of the FRAND commitment, but it is not likely to help in situations where the previous owner did not engage in intentional wrongdoing.

The patent-related claims that concern FRAND commitments occasionally overlap with contract law claims, but not always in the same litigation. The interrelated nature of disputes over patents and FRAND commitments can lead to litigation being severely impeded, especially when the disputes are being addressed by different courts. Consider, for example, the Delaware case of Rembrandt Technologies v. Harris Corp. ${ }^{191}$ and the concurrent multidistrict litigation (MDL), In re Rembrandt Technologies, $L P .{ }^{192}$ In the litigation against Harris, one of the issues concerned the ' 627 patent and the application of a FRAND commitment that AT\&T, Rembrandt's predecessor in interest, made to the Advanced Television

185. Id. at 1582 .

186. Id. at 1575 .

187. Lemley, supra note 19, at 1923-24.

188. See Barnes \& Noble, Inc. v. LSI Corp., 849 F. Supp. 2d 925, 932 (N.D. Cal. 2012) (noting that fraud prior to issuance and subsequent to issuance can make a patent unenforceable).

189. Id. at 930 .

190. Id. at 932 .

191. No. 07C-09-059-JRS, 2009 WL 1509103, at*1 (Del. Super. Ct. May 22, 2009) (“At the initial scheduling conference, the Court was advised that multi-district patent litigation (to which Harris is not a party) involving the " 627 patent was ongoing in the United States District Court for the District of Delaware.").

192. 493 F. Supp. 2d 1367 (J.P.M.L. 2007). 
Systems Committee (ATSC) during the promulgation of the HDTV standard. ${ }^{193}$ Harris was not a party to the MDL, but the ' 627 patent's validity was being challenged in the MDL, so Rembrandt sought Harris's admission as to the '627 patent's validity. ${ }^{194}$ If Harris had admitted to the patent's validity in the FRAND litigation, Rembrandt could have used that admission as evidence in the patent litigation. The concurrent disputes led to changes in the parties' positions in the Delaware litigation when there were changes in the status of the MDL proceedings, to the occasional frustration of the courts. ${ }^{195}$ Patent issues, patent-based theories to address FRAND commitment issues, and contract claims would ideally be treated by the same court that has full access to information from the parties, but as Rembrandt shows, jurisdiction issues may make this difficult. This is another topic that is ripe for further analysis by policy professionals and academics.

\section{b. Insufficiency of Patent Law to Address FRAND Problems}

Patent law does not provide viable recourse when FRAND commitments are disregarded by assignees. The patent law doctrines of equitable estoppel and implied licenses are likely to be ineffective as defenses against patent litigation over SEPs. These doctrines are derived from some representation made by the patentee that is relied on by the infringer. ${ }^{196}$ Because of the lack of relationship between nonmembers and patent owners, an argument is likely to fail if it argues that a defense of laches, equitable estoppel, or an implied license supports FRAND commitment enforceability by nonmembers. A defense of equitable estoppel may, however, be available to SSO members if a court concludes that membership in the same SSO is sufficient to infer a relationship. These defenses, however, are unlikely to be very helpful in the context of after-acquired patents, as it is likely unreasonable to infer that a representation was made as to a patent that is not yet owned.

\section{Antitrust and Unfair Competition}

A second major area of law that is raised in the SSO context is antitrust and unfair competition. ${ }^{197}$ Lemley notes that to establish an antitrust violation of

193. Rembrandt Techs., 2009 WL 1509103 , at *6 n.8.

194. Id. at *1 ("If Harris admitted infringement, then the admission could be used as evidence in the prosecution of the patent litigation. If Harris denied infringement, then, based on the language of the commitment on which Harris' demand for the license was based, Rembrandt would not owe a license to Harris and this case would be over. The Court denied the motion.").

195. Id. ("Throughout the life of this litigation, the parties have used this action principally as a device to gain strategic advantages in related multi-district federal patent litigation. Positions taken here come and go with the changing tides of the federal litigation.").

196. See Wang Labs. Inc. v. Mitsubishi Elecs. Am., Inc., 103 F.3d 1571, 1580 (Fed. Cir. 1997) (implied license); A.C. Aukerman Co. v. R.L. Chaides Constr. Co., 960 F.2d 1020, 1043 (Fed. Cir. 1992) (equitable estoppel).

197. Because of the nature of SSOs as organizations of competitors, there are sometimes 
monopolization or attempted monopolization under the Sherman Act, the party must prove the defendant's "market power, anticompetitive conduct, and intent." 198 Remedies for antitrust violations may include treble damages, attorney's fees, and enforcement by antitrust authorities. ${ }^{199}$ The law of unfair competition, especially as set forth in section 5 of the FTC Act, ${ }^{200}$ is a body of law that often overlaps with antitrust law, though the term "antitrust" may also be understood in a more limited sense to refer to the Sherman and Clayton Acts. We discuss both Sherman Act claims and section 5 unfair competition claims in Part II.B.2.a.

The overlap of antitrust law and patent law is the subject of much discussion among academics. ${ }^{201}$ Antitrust law aims to prevent abuses through monopolistic and anticompetitive behaviors, but some monopolies are lawful and permitted. Patents, for instance, always create a monopoly, and courts generally act with more deference to the patent system when weighing monopolistic behaviors by patent owners. ${ }^{202}$ SEPs, however, have the potential to be more harmful to competition and the market if that monopoly power is abused. When a patent owner has an SEP, therefore, a court may weigh the owner's behavior as a patent owner against his obligations under antitrust law, affording somewhat less deference to the nature of the patent as a legal monopoly. ${ }^{203}$ However, Mossoff notes that there are many concerns about whether courts that shape antitrust law have an adequate understanding of the effects that such rulings might have on future technological innovation. ${ }^{204}$

In the following Parts, we examine antitrust case law in more detail. As analysis of the case law shows, the viability of antitrust claims in the FRAND litigation context is ultimately unclear under U.S. law.

questions about whether the SSOs themselves violate antitrust law. See Lemley, supra note 19, at 1937 (noting the existence of this argument). However, courts typically acknowledge the pro-competitive value of SSOs. See, e.g., Intel Corp. v. Via Techs., Inc., 174 F. Supp. 2d 1038, 1040 (N.D. Cal. 2001) ("Without [technology standards], the industry would balkanize, improvements would slow, and consumers would suffer."). Some scholars note, however, that the risk of violating antitrust law might partially explain why SSOs keep a "hands off" approach to licensing and the interpretation of FRAND. E.g., Layne-Farrar et al., supra note 42 , at $678-79$.

198. Lemley, supra note 19, at 1928.

199. Id. at 1927.

200. 15 U.S.C. $\S 45$ (2006).

201. See, e.g., Michael A. Carrier, Unraveling the Patent-Antitrust Paradox, 150 U. PA. L. REV. 761 (2002) (discussing the intersection of patent and antitrust law); James Gould \& James Langenfeld, Antitrust and Intellectual Property: Landing on Patent Avenue in the Game of Monopoly, 37 IDEA 449 (1997) (discussing the Clinton administration's approach to antitrust issues in intellectual property).

202. Merges \& Kuhn, supra note 30 , at 14 (noting that authorities faced with antitrust claims often defer to patent law because of patent law's inherent tradeoff between competition benefits and incentives for innovation).

203. See Broadcom Corp. v. Qualcomm Inc., 501 F.3d 297, 314 (3d Cir. 2007) (holding that patent holdup in the form of unexpected enforcement of a declared essential patent was actionable under antitrust law).

204. Adam Mossoff, A Simple Conveyance Rule for Complex Innovation, 44 Tulsa L. REV. 707, 735-36 (2009) (noting the institutional competence concerns). 


\section{a. Antitrust and Unfair Competition Cases}

Scholars and courts alike have often focused on competition law's potential to address issues relating to standards and FRAND commitments. ${ }^{205}$ Antitrust law and the law of unfair competition are areas that are largely based on case law, because the governing statutes (e.g., the Federal Trade Commission Act, the Sherman Act, and the Clayton Act) are written in very high-level and general language. Thus, fact-specific inquiries are very important in antitrust and unfair competition cases. $^{206}$

Perhaps due in part to antitrust's reliance on fact-specific inquiries, the legal conclusions about FRAND commitments and antitrust have been spotty. The case of Broadcom Corp. v. Qualcomm Inc., ${ }^{207}$ for example, emphasizes that there may be antitrust liability when there is active deception of the SSO. ${ }^{208}$ Similarly, in Research In Motion Ltd. v. Motorola, Inc. ${ }^{209}$ the court concluded that Motorola's breach of a FRAND commitment was harmful to competition. ${ }^{210}$ The court in Vizio, Inc. v. Funai Electric Co. ${ }^{211}$ reasoned that there may also be antitrust liability when there is an active attempt to conspire to harm competition. ${ }^{212}$ However, under the reasoning in Vizio, the mere transfer of a patent is likely not enough to show anticompetitive behavior, and a refusal to abide by the FRAND commitment made by a predecessor in interest is not inherently harmful to competition. ${ }^{213}$

The cases also indicate a trend toward requiring active deception of an SSO for antitrust liability to attach under the Sherman Act. The important case of Rambus Inc. v. $F T C^{214}$ held that mere failure to disclose a patent application, even when the patent owner appears to have intentionally amended a patent application to make the claims fall within the standard specifications, would not sufficiently establish anticompetitive harm if the concealment was intended to avoid the royalty limits imposed by a FRAND commitment with the SSO. ${ }^{215}$ The Rambus court also held the FTC to a high causation bar, requiring a showing that, but for the concealment, the SSO would have chosen an alternative technology. ${ }^{216}$ Rambus further

205. E.g., George S. Cary, Mark W. Nelson, Steven J. Kaiser \& Alex R. Sistla, The Case for Antitrust Law to Police the Patent Holdup Problem in Standard Setting, 77 AnTITRust L.J. 913 (2011); Speegle, supra note 23; Joshua D. Wright \& Aubrey N. Stuempfle, Patent Holdup, Antitrust, and Innovation: Harness or Noose?, 61 Ala. L. ReV. 559 (2010).

206. See, e.g., Maurice E. Stucke, Does the Rule of Reason Violate the Rule of Law?, 42 U.C. DAVIS L. REV. 1375, 1375 (2009) (referring to the rule-of-reason standard as turning on a fact-specific inquiry).

207. 501 F.3d 297 (3d. Cir. 2007).

208. Id. at 314 .

209. 644 F. Supp. 2d 788 (N.D. Tex. 2008).

210. Id. at 796 .

211. No. CV 09-0174 AHM (RCx), 2010 WL 7762624 (C.D. Cal. Feb. 3, 2010).

212. See id. at *6.

213. $I d$. at $* 4-5$.

214. 522 F.3d 456 (D.C. Cir. 2008).

215. Id. at 459 ("But the latter - deceit merely enabling a monopolist to charge higher prices than it otherwise could have charged-would not in itself constitute monopolization.").

216. Id. at $466-67$. 
emphasizes the Supreme Court case of NYNEX Corp. v. Discon, Inc. ${ }^{217}$ for the principle that fraudulent behavior along with harm to consumers in the form of increased prices was not a per se antitrust violation where the increased cost to the consumer could be attributed to the exercise of a lawful monopoly power. ${ }^{218}$ The Rambus court's reading of NYNEX is problematic for plaintiffs in antitrust cases concerning patents in general and is potentially broad enough to restrict or eliminate the application of antitrust law in cases involving patents that are part of a standard.

Because of cases like Rambus and Vizio, the application of antitrust law as a solution for a FRAND commitment dispute may be very limited. When there is an omission instead of an active attempt at deception, the reasoning of Rambus may persuade a court to find against antitrust liability. Similarly, Vizio seems to stand for the idea that antitrust liability does not automatically follow the patent. While Vizio left it open for antitrust liability to attach to conspiracies to harm competition, it also deferred to the patent owners with respect to the issues of patent transfer and repudiation of commitments made by a predecessor in interest.

Similarly, as seen in Apple, Inc. v. Motorola Mobility, Inc., the NoerrPennington doctrine may limit the ability of defendants to raise antitrust issues as counterclaims upon being sued for infringement. ${ }^{219}$ Because of the NoerrPennington doctrine, antitrust counterclaims in response to a patent infringement suit may be limited to the extent that assertion of patent rights is viewed as the anticompetitive conduct.

The FTC, which is one of the agencies authorized to enforce antitrust law, has also been very involved with these issues. ${ }^{220}$ Rambus overturned an FTC opinion where the FTC concluded that Rambus's actions did amount to anticompetitive conduct. ${ }^{221}$ When the FTC decided the case against Rambus, it drew on both section 2 of the Sherman Act and section 5 of the FTC Act, finding that Rambus had unlawfully monopolized several technology markets through its deceptive conduct. $^{222}$ However, the D.C. Circuit did not address the section 5 aspects, because the FTC did not raise section 5 in its case before the D.C. Circuit. ${ }^{223}$

Some FTC adjudications result in consent decrees, which focus on prohibiting future actions like the behavior under investigation, and the entry of a consent

217. 525 U.S. 128 (1998).

218. Rambus, 522 F.3d at 465 (citing NYNEX Corp., 525 U.S. 128).

219. See Apple, Inc. v. Motorola Mobility, Inc., 886 F. Supp. 2d 1061, 1066 (W.D. Wis. 2012). The Noerr-Pennington doctrine is often understood as being based on the First Amendment. In Apple v. Motorola, the court held that the Noerr-Pennington doctrine applied because Apple's claim about Motorola's anticompetitive conduct arose from Motorola's attempt to enforce its patents in court, and thus the counterclaim was dismissed on summary judgment. Id.

220. Raymond Z. Ling, Note, Unscrambling the Organic Eggs: The Growing Divergence Between the DOJ and the FTC in Merger Review After Whole Foods, 75 BROOK. L. REV. 935, 937 (2010) (noting that "the DOJ and the FTC have shared responsibility for enforcement of the federal antitrust laws").

221. Rambus, 522 F.3d at 469.

222. See id. at 461 .

223. Id. at 467. 
decree requires the parties to withdraw the matter from adjudication. ${ }^{224}$ Many of these involve section 5 of the FTC Act. ${ }^{225}$ One of the first examples in the information age where the FTC investigated a company for standards-related misbehavior is In re Dell Computer Corp. ${ }^{226}$ There, the FTC found that Dell had violated section 5 of the FTC Act by failing to disclose its interest in an SEP and then exercising its rights against implementers of the standard eight months after the standard was adopted. ${ }^{227}$ Under the consent decree, Dell agreed that it would not assert its IPR in the relevant standard. ${ }^{228}$

Another section 5-based FTC adjudication, which also resulted in a consent decree, involved the actions of Negotiated Data Solutions LLC (NData). ${ }^{229}$ In that case, the FTC ordered NData to comply with the terms of FRAND commitments that its predecessor in interest (National Semiconductor Corp.) made with the Standards Association of the Institute of Electrical and Electronics Engineers, Inc. (IEEE-SA) ${ }^{230}$ In the NData adjudication, the FTC concluded that NData's actions with regard to the patent amounted to unfair competition under section 5 of the FTC Act, 15 U.S.C. § 45, but the FTC did not establish a standard for determining when there are unfair practices in the standard-setting context. ${ }^{231}$ Merges and Kuhn also point to the lack of a unanimous decision in NData as indicative of antitrust's inadequacy to address issues in the SSO context. ${ }^{232}$

Recently, the FTC investigated Google's activities relating to patents obtained when Google acquired Motorola Mobility (MM). ${ }^{233} \mathrm{MM}$ had many patents that were considered to be SEPs, and prior to Google's acquisition, MM threatened to seek injunctions against companies like Microsoft, Apple, and RIM for their use of these SEPs. ${ }^{234}$ Google then continued these practices, and the FTC's initial order, published in January 2013, asserts that this pattern of injunction-seeking behavior in the case of SEPs is a violation of section 5.235

As the Rambus case shows, the FTC is held to strict standards on review when FTC adjudication is based on the Sherman Act, claims of monopolistic behavior, and outright restraints on trade. ${ }^{236}$ The FTC currently has broader discretion to

224. 16 C.F.R. $\S 3.25$ (2013).

225. 15 U.S.C. $\S 45$ (2006).

226. 121 F.T.C. $616,618-19$ (1996) (consent decree).

227. Id. at $617-19$.

228. Lemley, supra note 19, at 1928-29.

229. In re Negotiated Data Solutions LLC, FTC File No. C-0510094 (decision and order, Sept. 23, 2008), http://www.ftc.gov/os/caselist/0510094/080122do.pdf.

230. See id.

231. See Merges \& Kuhn, supra note 30, at 3 (commenting on the FTC's findings in the NData proceeding).

232. Id. (suggesting that NData should have been an obvious case for finding anticompetitive behavior).

233. Motorola Mobility LLC and Google Inc.; Analysis of Proposed Consent Order to Aid Public Comment, 78 Fed. Reg. 2398, 2399 (Jan. 11, 2013).

234. Id. at $2400,2405$.

235. Id. at 2400 ("The Proposed Complaint alleges that Motorola and Google's conduct violates Section 5 of the FTC Act, both as an unfair method of competition and an unfair act or practice.").

236. See Rambus Inc. v. FTC, 522 F.3d 456 (D.C. Cir. 2008). 
adjudicate possible violations of section 5's unfair competition language. ${ }^{237}$ Application of section 5 of the FTC Act through FTC adjudication thus may still preserve a viable outlet for antitrust and unfair competition theories in the context of the transferability of FRAND commitments. However, the remedies available for FTC actions under section 5 are narrower than those available for violations of sections 1 and 2 of the Sherman Act, as we examine in more detail below. In the alternative, Speegle suggests that rulemaking under section 5 might prove beneficial to addressing issues that arise in the standards context. ${ }^{238}$

\section{b. Insufficiency of Antitrust to Address FRAND Problems}

In the standard-setting context, competition law has been one of the most visible aspects of the law governing these disputes. As noted above, however, the case law on antitrust issues indicates that this body of law may not be well suited for the current controversy. As is the case in other areas of ex-post adjudication, antitrust claims ultimately cannot be brought until an injury has already occurred, and any positive resolution for the injury must then wait until the conclusion of potentially protracted and complicated litigation. Thus, consumer injury may be magnified by the inherently ex-post nature of antitrust remedies.

The nature of antitrust law in the United States is the primary reason why this area of law will not be sufficient to address FRAND problems. For a claim to be brought under the Sherman Act, the law typically requires a showing of specific intent to engage in anticompetitive behavior, ${ }^{239}$ and the existence of anticompetitive behavior is evaluated through a number of tests that each set very high bars. First, antitrust claims under the Sherman Act are dismissed if the court does not think that sufficient harm to competition has been alleged, which in the patent and standards context, typically requires a showing of harm to competition in general, not just harm to the alleged infringer. ${ }^{240}$ Second, as Rambus shows, a broad application of the principles of NYNEX to the standard-setting context can lead to a conclusion that harm to consumers arising from a party charging others more for access to the party's lawful monopoly (e.g., a patent) might require a stronger showing to establish an anticompetitive harm that can be addressed under antitrust law. ${ }^{241}$ Third, under the Noerr-Pennington doctrine, the ability to raise antitrust issues in a counterclaim is severely impeded, ${ }^{242}$ so antitrust theories might not be helpful for supporting a counterclaim in a suit for patent infringement. There is also case law that suggests that relying on antitrust law for the transferability of FRAND commitments would not work, because as a default rule, the obligations under

237. See Speegle, supra note 23 , at $849-50$.

238. Id. at 847.

239. Lemley, supra note 19 , at 1928.

240. E.g., ESS Tech., Inc. v. PC-TEL, Inc., No. C-99-20292 RMW, 1999 WL 33520483, at *3 (N.D. Cal. Nov. 4, 1999) ("The court finds that plaintiff has failed to sufficiently allege injury to competition beyond the impact on plaintiff.").

241. Rambus, 522 F.3d at 465 (citing NYNEX Corp. v. Discon, Inc., 525 U.S. 128 (1998)).

242. See Apple, Inc. v. Motorola Mobility, Inc., 886 F. Supp. 2d 1061, 1066 (W.D. Wis. Aug. 10, 2012). 
antitrust law with respect to FRAND commitments would primarily apply to the party that makes the FRAND commitment and would not transfer to a successor in interest. $^{243}$

Claims brought under section 5 of the FTC Act, claiming "unfair methods of competition" or "unfair or deceptive acts or practices," may be more likely to succeed, but with lesser remedies than under the Sherman Act. In civil litigation brought under the Clayton Act, civil litigants may be able to obtain treble damages and attorney fees, ${ }^{244}$ and in FTC adjudication under the Sherman Act, a company may be fined or ordered to disgorge profits. ${ }^{245}$ In contrast, section 5 authorizes the FTC to grant orders requiring the violator to cease and desist from the found violations, ${ }^{246}$ but case law suggests that this "cease and desist" authority does not include the power to order the violator to pay restitution to injured parties. ${ }^{247}$ Violation of a final order may result in a fine of up to $\$ 10,000$ per violation, with federal district courts also being authorized to grant mandatory injunctions in the interest of enforcing the final order. ${ }^{248}$ While the possibility of injunctions to enforce FTC orders has promise in the SSO context, the threat of a $\$ 10,000$ fine per violation may not have much bite. The $\$ 10,000$ fine has been in the statute since $1973,{ }^{249}$ when $\$ 10,000$ had the buying power of over $\$ 50,000$ in 2012 dollars. ${ }^{250}$

Though antitrust law is unlikely to assist in issues relating to the transfer of SEPs, the law of unfair competition may have promise for extending FRAND commitments to commercially essential patents and for applying the FRAND commitment to benefit nonmembers of the SSO. Applying European competition law, the European Commission (EC) recently examined the possibility of requiring owners to grant access to commercially essential technologies in the context of

243. Vizio, Inc. v. Funai Elec. Co. Ltd., No. CV 09-0174 AHM (RCx), 2010 WL 7762624 (C.D. Cal. Feb. 3, 2010). However, agreements or external forces can intervene to make these agreements transfer. For example, in the Nortel bankruptcy proceeding, the court specified that the patents would be transferred subject to agreements with standard-setting organizations. The Department of Justice has also indicated (after an initial investigation) that it would continue to watch Google, Apple, Microsoft, and Research In Motion to ensure that these companies do not use newly acquired SEPs in a way that would be anticompetitive, and that these companies comply with their own promises to be bound by the previous patent owners' promises to SSOs. Press Release, Dep't of Justice, Statement of the Department of Justice's Antitrust Division on Its Decision to Close Its Investigations of Google Inc.'s Acquisition of Motorola Mobility Holdings Inc. and the Acquisitions of Certain Patents by Apple Inc., Microsoft Corp. and Research In Motion Ltd. (Feb. 13, 2012), available at http://www.justice.gov/atr/public/press_releases/2012/280190.htm.

244. 15 U.S.C. $\S 15$ (2006).

245. FTC v. Mylan Labs., Inc., 62 F. Supp. 2d 25, 35-37 (D.D.C. 1999) (evaluating the FTC's authority to seek injunctions and disgorgement of profits); see also Edward Cavanagh, Antitrust Remedies Revisited, 84 OR. L. REV. 147 (2005).

246. 15 U.S.C. $\S 45($ b) (2006).

247. See Heater v. FTC, 503 F.2d 321, 326 (9th Cir. 1974); see also Peter C. Ward, Restitution for Consumers Under the Federal Trade Commission Act: Good Intentions or Congressional Intentions?,41 AM. U. L. REV. 1139, 1144 (1992).

248. 15 U.S.C. $\S 45(l)(2006)$.

249. Act of Nov. 16, 1973, Pub. L. No. 93-153, § 408(c), 87 Stat. 591.

250. CPI Inflation Calculator, http://data.bls.gov/cgi-bin/cpicalc.pl. 
evaluating Google's acquisition of Motorola Mobility. ${ }^{251}$ There, the Commission noted that "in exceptional circumstances, notably where a technology has become an indispensable input for competitors, a refusal to grant access to that technology may be abusive." ${ }^{252}$ However, the Commission's opinion emphasized that this would be a fact-intensive inquiry. ${ }^{253}$ If policymakers decree that competitors should be granted access to commercially essential patents or face possible investigations, the policy could strike a balance between acknowledging this obligation and not imposing excessive liability on patent owners by limiting claims to redress under section 5 of the FTC Act.

We also anticipate that antitrust law and the law of unfair competition could permit nonmembers of the SSO to benefit from the FRAND commitment. The focus of these areas of law is on the market as a whole rather than on specific parties to a contract. ${ }^{254}$ As the Dell adjudication shows, the FTC has been willing to require patent owners to agree to not assert their IP rights in a standard. ${ }^{255}$ Further clarification and analysis on this point may be beneficial, but it appears that a consent decree that is adopted in response to a patent owner's refusal to negotiate for a license could require the patent owner to engage in good faith negotiations with potential licensees.

We express doubts, however, that either antitrust law or the law of unfair competition would assist with the problems surrounding after-acquired patents in the United States. For after-acquired patents, we look to the reasoning of the Rambus and Vizio cases to conclude that antitrust law is not likely to apply to afteracquired patents in the absence of a conspiracy to monopolize. ${ }^{256}$ If the SSO's policy addresses after-acquired patents, this may make the problem capable of being redressed under contract law, but we do not think that such contract language would automatically affect the antitrust issues. Because of the importance of contracts in these disputes, we now turn to an examination of contract law.

\section{Contract}

Contract law is especially relevant to these disputes, because FRAND commitments are typically recognized as being valid contracts between the SSO and the patent owning member. ${ }^{257}$ The IPR policies of many SSOs say that, if the patent owner refuses to make a FRAND commitment, the SSO may decline to use

251. Commission Regulation (EC) No. 139/2004, Case No COMP/M.6381, Google/Motorola Mobility Commission Decision Pursuant to Article 6(b)(1) of Council Regulation No 139/2004 [hereinafter Commission Regulation], available at http://ec.europa.eu /competition/mergers/cases/decisions/m6381_20120213_20310_2277480_EN.pdf.

252. Id. at 959 .

253. Commission Regulation, supra note 251.

254. See Rambus Inc. v. FTC, 522 F.3d 456, 463 (D.C. Cir. 2008) (emphasizing that to be actionable, behavior must have an anticompetitive effect on the market, not just an adverse effect on specific competitors).

255. In re Dell Computer Corp., 121 F.T.C. 616 (1996) (consent decree).

256. See Rambus, 522 F.3d at 463; Vizio, Inc. v. Funai Elec. Co. Ltd., No. CV 09-0174 AHM (RCx), 2010 WL 7762624 (C.D. Cal. Feb. 3, 2010).

257. See, e.g., Microsoft Corp. v. Motorola, Inc., 864 F. Supp. 2d 1023 (W.D. Wash. 2012). 
the patented technology in the standard. Lemley's analysis suggests that a FRAND commitment that is part of an SSO's bylaws becomes an enforceable contract when the SSO member accepts these terms of membership, ${ }^{258}$ but some SSOs specifically state that the SSO will not get involved with licensing disputes. ${ }^{259}$ If the FRAND commitment is a contract that is enforceable against the patent owner, and the SSO states that it will not get involved in licensing disputes, Merges and Kuhn note that this raises difficult questions relating to whom can enforce the contract and what the available remedies might be. ${ }^{260}$

This Part focuses mostly on the application of formal contract law but also discusses the application of detrimental reliance. A detrimental reliance theory would be partially grounded in contract law, but the available remedies would be equitable rather than legal. ${ }^{261}$

\section{a. Contract Cases}

Because a FRAND commitment is typically viewed as a contract, much of the litigation in the FRAND commitment context focuses on formal contract law. The FRAND commitment is between the patent holder and the SSO, but does it really create a contract? When approaching these problems from a formal contract perspective, this is the threshold question. Fortunately, it is also a threshold question that has been repeatedly answered in the affirmative, at least when the question is whether the agreement creates a contract between the patent owner and the SSO. ${ }^{262}$ In Microsoft v. Motorola, the court concluded that a FRAND commitment is a valid contract, because the commitment involves an offer, an acceptance, and consideration. ${ }^{263}$ There, the court concluded that the SSO's

258. Lemley, supra note 19, at 1910-11.

259. E.g., INT'L Electrotechnical COMM'N ET AL., supra note 40, at 1 ("The Organizations should not be involved in evaluating patent relevance or essentiality with regards to Recommendations | Deliverables, interfere with licensing negotiations, or engage in settling disputes on Patents; this should be left-as in the past-to the parties concerned.").

260. Merges \& Kuhn, supra note 30 , at 14.

261. See id. at 4 (suggesting that a "reliance interest" should be recognized when a standard adopter uses a standard over time).

262. However, courts in several countries have rejected an argument that a FRAND commitment is an offer to license that can be accepted by use of the patent. E.g., Apple Inc. v. Samsung Elecs. Co., No. 11-CV-01846, 2012 WL 1672493, at*14 (N.D. Cal. May 14, 2012) ("[I]t is not plausible that Samsung's FRAND declarations constitute an offer to license.”); Samsung Elecs. Co. v. Apple Inc., No. 45629-112011 (Ct. of Milan Jan. 5, 2012) (section specialized in industrial and intellectual property matters); Samsung Elecs. Co. v. Apple Inc., No. LJN: BT7610 (District Ct. of The Hague Oct. 14, 2011); see also Gen. Instrument Corp. v. Microsoft Deutschland GmbH, Landgericht Mannheim [Regional Court of Mannheim] May 2, 2012, 1, 38 (Ger.), available at http://www.scribd.com/doc/94523005 /Translation-of-Mannheim-2O240-Ruling-Motorola-v-Microsoft ("[T]he Patent Statement and Licensing Declaration Form . . . cannot be understood as a binding license offer to any number of third parties unknown to the Plaintiff, requiring only acceptance by a third party, but as a request to license seekers to submit their own FRAND offers ....").

263. Microsoft Corp. v. Motorola, Inc., 864 F. Supp. 2d 1023 (W.D. Wash. 2012). 
promise to include or consider including the patent in the standard in exchange for the FRAND commitment was consideration. ${ }^{264}$ On an interlocutory appeal concerning a related injunction issued against Microsoft by a German court, the Ninth Circuit concluded that the district court's characterization of a FRAND commitment as a valid contract was not legally erroneous. ${ }^{265}$

So there is a valid contract, but the contract was created by an agreement between the patent owner and the SSO. If a patent owner violates the agreement, the SSO could sue as the other party to the contract, but the policies of many SSOs indicate that the SSO will not get involved in licensing disputes. ${ }^{266}$ If the SSO will not hold the patent owner liable for violating a FRAND commitment, who else can? What about the potential adopters of the standard? Do they have a claim against the patent owner for breach of contract? So far, under the law of the United States, the answer has been yes. ${ }^{267}$ The standard adopters are likely to be third-party beneficiaries under the contract, which means that they receive a direct benefit from the contract even though they are not a party to the contract. ${ }^{268}$ In the case of FRAND commitments, these contracts are specifically intended to benefit parties that want to adopt the standard, so there is a solid argument for these adopters being third-party beneficiaries. In Microsoft v. Motorola, the court specifically noted that Microsoft (a member of the SSO) was a third-party beneficiary of the FRAND commitments that Motorola made to the SSO ${ }^{269}$ It would also lead to unjust results if a patent owner who makes a FRAND commitment was permitted to sue standard adopters for infringement, but the standard adopters were not allowed to rely on the FRAND commitment as part of their legal theory. However, this conclusion is not universal across all jurisdictions. German contract law, for instance, typically does not recognize third-party rights in a contract. ${ }^{270}$

But many questions are still unresolved. So far, most of the litigation involving questions of third-party beneficiaries to a FRAND commitment has occurred in a context where the third-party beneficiary was a member of the SSO. ${ }^{271}$ Thus, case law is currently unclear as to whether a nonmember would be considered a third-party beneficiary, though there is at least one case where a court permitted a claim to proceed where a nonmember of the SSO in question sought to enforce a

264. Id. at 1024.

265. Microsoft Corp. v. Motorola Inc., 696 F.3d 872, 884 (9th Cir. 2012).

266. See, e.g., InSt. Of ElEC. AND EleCs. ENG'RS STANDARDS Ass'N, supra note 73, § 6 (stating that IEEE is not responsible for determining if a proposed license is reasonable and nondiscriminatory).

267. E.g., Realtek Semiconductor Corp. v. LSI Corp., No. C-12-03451-RMW, 2013 WL 2181717, at *5 (N.D. Cal. May 20, 2013).

268. Id.

269. Microsoft Corp., 864 F. Supp. 2d at 1032.

270. E.g., Gen. Instrument Corp. v. Microsoft Deutschland GmbH, Landgericht Mannheim [Regional Court of Mannheim] May 2, 20121 (Ger.), available at http://www.scribd.com/doc/94523005/Translation-of-Mannheim-2O240-Ruling-Motorola-v -Microsoft (stating that the ITU Patent Statement and Licensing Declaration is not "a contract to the benefit of third parties.").

271. E.g., Microsoft Corp., 864 F. Supp. 2d 1023. 
FRAND commitment made by a patent owner and its predecessor-in-interest. ${ }^{272}$ In the ESS Technology case, the question of SSO membership did not figure into the analysis, which may indicate that protests based on the member-nonmember distinction are purely academic in nature.

Lemley, however, warns that allowing nonmembers to enforce a FRAND commitment would make the public at large into third-party beneficiaries. ${ }^{273}$ In our view, nonmembers of the SSO who fall within the class of "standard adopters" should be eligible to enforce a FRAND commitment as a third-party beneficiary, because the class of "standard adopters" is a distinct class and is not the same thing as allowing the FRAND commitment to be enforced by the public at large. The patent owner would not be bound by the FRAND commitment in the case of all infringements, just infringements that involve use of the patented technology to comply with the standard.

What does this contract create? In the case of Apple v. Samsung, the parties agreed that Samsung's FRAND declaration to ETSI was a contract that at least created a duty for Samsung to negotiate licenses in good faith. ${ }^{274}$ In Microsoft v. Motorola, Motorola attempted to argue that the FRAND commitment imposes this duty to negotiate in good faith on the potential licensee, such that if the patent owner makes the first contact with the potential licensee, the obligation to license on FRAND terms is expunged. ${ }^{275}$ However, the court rejected this argument, reasoning that it would defeat the purpose of a FRAND promise if the patent owner could evade the obligation by making first contact. ${ }^{276}$ The court further rejected Motorola's argument that Microsoft repudiated the FRAND commitment by filing suit against Motorola instead of negotiating for a license. ${ }^{277}$ In the court's February 27, 2012, ruling granting a partial summary judgment, the court opined that a potential licensee would not be repudiating an agreement if the potential licensee filed suit to request that a court determine whether terms comported with the FRAND commitment. ${ }^{278}$ This dicta was made official in the court's June 6, 2012, ruling on separate summary judgment motions. ${ }^{279}$

272. See ESS Tech., Inc. v. PC-TEL, Inc., No. C-99-20292 RMW, 1999 WL 33520483, at *3-4 (N.D. Cal. Nov. 4, 1999).

273. Lemley, supra note 19, at 1915.

274. Apple Inc. v. Samsung Elecs. Co., No. 11-CV-01846, 2012 WL 1672493 (N.D. Cal. May 14, 2012). The court rejected Apple's argument that it already had a license based on a theory that the FRAND commitment constituted an offer to license that Apple could accept by using the patent. $I d$. at *13-14.

275. Microsoft Corp., 864 F. Supp. 2 d 1023.

276. Id. at 1034-35.

277. Id. at 1036.

278. Microsoft Corp. v. Motorola, Inc., 854 F. Supp. 2d 993, 1002 (W.D. Wash. 2012) ("As stated above, the court believes that reasonable parties may disagree as to the terms and conditions of a RAND license, leaving the courthouse as the only viable arena to determine the meaning of 'reasonable' under the circumstances. It would be illogical, therefore, to deem it repudiation of one's rights under a policy to file a lawsuit to enforce one's rights under that same policy.").

279. Microsoft Corp., 864 F. Supp. 2d at 1034 ("[T] the intent of the contracting parties (Motorola and the IEEE/ITU) to require that implementer of a standard first apply for a license and then negotiate for a license in good faith before 
If the SSO only requires the license to be granted on FRAND terms, is the patent owner obligated by the FRAND commitment to make an initial offer on FRAND terms? In Microsoft v. Motorola, the court said no, but ruled the initial offer "must comport with the implied duty of good faith and fair dealing." 280 This reasoning suggests that negotiations for royalty payments must start at a point that is not so far from FRAND that it appears to be made in bad faith. There, Motorola's initial offer to license the patent to Microsoft was at a $2.25 \%$ royalty per unit. ${ }^{281}$ By including the "good faith and fair dealing" language, the court retained the authority to review the propriety of the initial offer, without inserting new language into a contract that, on its face, only refers to the granted license and not the initial offer. ${ }^{282}$

While a standard implementer might choose to sue for breach of contract due to an excessive initial royalty offer, a more likely scenario is that the parties might fail to reach an agreement after prolonged negotiations. The standard implementer might then file suit, claiming that by failing to reach an agreement, the patent owner breached the contract with the SSO. In one such case, the mobile phone companies Ericsson and Samsung sued each other after reaching a stalemate in an attempted renegotiation of a cross-license of SEPs. ${ }^{283}$ Both companies asserted that the other party's failure to reach an agreement was a breach of contract of the FRAND promise that each made to ETSI. ${ }^{284}$

If a FRAND commitment is construed as an enforceable contract, and the litigation continues to a final judgment, the court may be asked to determine a reasonable royalty under the contract. When analyzing the reasonable royalty question, some courts look to the 1970 case of Georgia-Pacific Corp. v. U.S. Plywood Corp., which set forth a very detailed fifteen-factor test for determining a reasonable royalty. ${ }^{285}$ The Georgia-Pacific factors, however, do not provide any guidance for calculating royalties, but only for determining whether proffered royalties are reasonable. ${ }^{286}$ In April 2013, Judge Robart of the Western District of Washington issued a 207-page decision in Microsoft v. Motorola, in what some are calling a landmark decision in FRAND commitments, ${ }^{287}$ where the court painstakingly goes through the most relevant Georgia-Pacific factors and several different theories to calculate royalties that would be consistent with Motorola's FRAND obligations. ${ }^{288}$

Sometimes, the reasonable royalty question is simplified by the existence of a number of other licenses for the same patent, but a court following the Georgia-

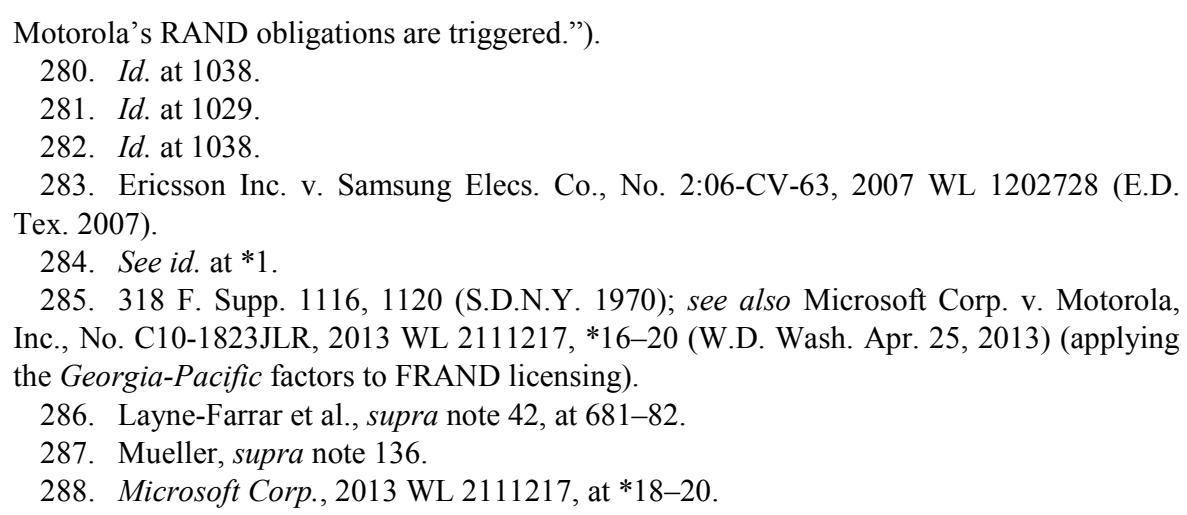


Pacific factors may emphasize that the existence of comparable royalty arrangements is only part of the test. ${ }^{289}$ Because owning an SEP gives the owner a greater power in negotiations, courts have also discussed a reasonable royalty for an SEP as being guided by the royalty that the patent would have warranted on its own in the absence of the standard. ${ }^{290}$ This is also a position supported by the FTC in its recent Intellectual Property Marketplace Report, in which the FTC recommended capping royalties at the licensing value of the patent at the time the standard was defined. ${ }^{291}$

\section{b. Litigation over FRAND Commitments-Transferability}

While contract theories are pretty straightforward when the litigation focuses on the obligations of the party who made the promise, the topic gets muddled when the patent starts changing hands. As we noted above in the context of bankruptcy law, licenses are often an easier case than FRAND commitments. ${ }^{292}$ The same is true in theories based on formal contract principles. In Intel, Inc. v. Negotiated Data Solutions, $L L C,{ }^{293}$ the court held a 1976 license valid even though the patent had been assigned multiple times and had been granted reissue by the USPTO since the license was initially created ${ }^{294}$ Similarly, in Rembrandt Data Technologies, LP v. $A O L L L C,{ }^{295}$ the current owner of the patent was found to be bound by the prior license agreement and subsequent sublicensing agreements. ${ }^{296}$ In that situation, both the patent and the license had been assigned multiple times. ${ }^{297}$

FRAND commitments, however, are potentially more complicated, because they do not create a license, and instead only leave open the possibility for a license. In Rembrandt Technologies, LP v. Harris Corp., which we also discuss in Parts II.B.1.a and III.B.4, a Delaware court ran the gamut, and so did the litigants. ${ }^{298}$ Harris sought a FRAND license from Rembrandt for the ' 627 patent, an HDTVrelated patent that was originally owned by AT\&T ${ }^{299}$ The same patent was also the subject of MDL in federal court, though Harris was not a party to that litigation. ${ }^{300}$ Based on the terms of the FRAND commitment that AT\&T entered into with the ATSC, the court initially granted Harris's motion for partial summary judgment on the issue that Rembrandt, as AT\&T's successor in interest to the relevant patent,

289. Id. at $* 20$ (discussing comparable licensing arrangements as one of the factors for determining a royalty rate, but not the sole controlling factor).

290. Apple, Inc. v. Motorola, Inc., 869 F. Supp. 2d 901, 913 (N.D. Ill. 2012).

291. FTC, supra note 8, at 194.

292. See supra text accompanying note 148.

293. 699 F. Supp. $2 d 871$ (E.D. Tex. 2010).

294. Id. at 876 .

295. 641 F.3d 1331 (Fed. Cir. 2011).

296. Id. at 1338 .

297. See id. at 1333-35.

298. No. 07C-99-059-JRS, 2008 WL 4824066 (Del. Super. Ct. Oct. 31, 2008).

299. Id. at *1.

300. Rembrandt Techs., L.P. v. Harris Corp., No. 07C-09-059-JRS, 2009 WL 2490873 (Del. Super. Ct. Aug. 14, 2009). 
owed Harris a FRAND license to essential patents. ${ }^{301}$ This ruling could potentially have helped standard adopters, but it quickly unraveled from there after a Markman hearing in the MDL suggested that the patent might be invalid, and the parties altered their theories in the Delaware proceeding accordingly. ${ }^{302}$ The Delaware court later vacated the earlier grant of partial summary judgment. ${ }^{303}$ Nonetheless, the court's initial approach to the question of whether a successor in interest is bound by the previous owner's FRAND commitment shows that courts may be receptive to contract-based arguments for the assignability of FRAND obligations, at least when, as here, the party seeking to enforce the FRAND commitment is a member of the SSO. ${ }^{304}$

\section{i. Transferability of FRAND Commitments in the EU}

Though the post-assignment status of FRAND commitments is unclear under U.S. law, the European Commission (EC) takes a much stronger position about FRAND commitments and the transferability of FRAND commitments pertaining to essential patents. The EC approach to transferability, however, is more likely to focus on competition law than on contract law.

In 2001, the EC set out guidelines for applying European competition law to "horizontal cooperation agreements," including SSOs. ${ }^{305}$ Specifically, paragraph 174 of the guidelines specifies that when industry actors work together to create a standard, "access to the standard must be possible for third parties on fair, reasonable and non-discriminatory terms." ${ }^{306}$ Paragraph 285 of the "Guidelines on the Applicability of Article 101 of the Treaty on the Functioning of the European Union to Horizontal Co-operation Agreements" duplicates this language, also adding a recommendation that the FRAND commitment be binding against assignees. ${ }^{307}$ In 2009 , the EC reacted favorably to IPCom's agreement to abide by

301. Rembrandt Techs., $2008 \mathrm{WL} 4824066$, at *1. Harris is listed as a member of ATSC. ATSC Members, Advanced Television Sys. Comm., http:/www.atsc.org/cms/index.php /policies/50-details/146-members.

302. Rembrandt Techs., 2009 WL 2490873, at*1.

303. Id.

304. However, we question in Part III.B.4 whether this court's analysis can really be fairly considered to be based on formal contract law.

305. Commission Notice - Guidelines on the Applicability of Article 81 of the EC Treaty to Horizontal Cooperation Agreements, 2001 O.J. (C 003), available at http://eur-lex.europa .eu/LexUriServ/LexUriServ.do?uri=CELEX:32001Y0106(01):EN:HTML; see also Press Release, European Comm'n, Antitrust: Commission Welcomes IPCom's Public FRAND Declaration (Dec. 10, 2009), available at http://europa.eu/rapid/press-release_MEMO-09 -549 en.htm.

306. Commission Notice - Guidelines on the Applicability of Article 81 of the EC Treaty to Horizontal Cooperation Agreements, supra note 305.

307. Commission Notice-Guidelines on the Applicability of Article 101 of the Treaty on the Functioning of the European Union to Horizontal Co-operation Agreements, 2011 O.J. (C 011), available at http://eur-lex.europa.eu/LexUriServ/LexUriServ.do?uri=OJ:C: 2011:011:0001:0072:EN:PDF. 
the FRAND commitment made by Bosch, its predecessor in interest to a number of SEPs. ${ }^{308}$

As noted above, antitrust law in the United States takes a potentially more restrictive view of FRAND commitments than does European competition law. Thus, transferability of FRAND commitments under U.S. law currently turns on the application of contract law, with antitrust law largely not being as applicable. On the other hand, transferability of the same agreements in the EU will likely rely on European competition law, with some European jurisdictions taking a position against the third-party beneficiary theory that allows for viable FRAND commitment enforcement under the formal contract law of the United States. ${ }^{309}$ In our view, a property-based approach may serve to unify both the United States and the EC on the issue of FRAND commitment transferability.

\section{c. Formal Contract Law and the FRAND Problems}

Parties to a contract can generally agree to anything that doesn't violate the law, isn't contrary to public policy, and doesn't render the contract so unfair as to be unconscionable. ${ }^{310}$ When a contract addresses all of the possible issues, and there is valid offer, acceptance, and consideration sufficient to support the formation of a contract, there would be no problem. ${ }^{311}$ However, there is currently no standard for standards - that is, SSOs vary significantly in how they address IP rights and FRAND commitments, and there are many things that may be left out of these agreements.

The first problem that we introduced in the above Widget hypothetical concerned the enforceability of a FRAND commitment by a party who was not a member of the SSO. This issue will largely be influenced by the IPR policy of the SSO and is likely to be resolved under U.S. contract law by reference to the thirdparty beneficiary doctrine. The FRAND commitment is typically recognized as being a valid contract, and the potential licensee is a third-party beneficiary of that contract. The Restatement (Second) of Contracts states that a party may be the intended beneficiary of a contract if the agreement indicates an intention to provide a right to the third party under the contract. ${ }^{312}$

In our view, a FRAND commitment in which the patent holder agrees to license on FRAND terms to anyone who intends to implement the standard clearly creates

308. European Comm'n, supra note 305.

309. See Microsoft Corp. v. Motorola, Inc., 696 F.3d 872, 879 (9th Cir. 2012) (discussing a German ruling in Motorola's favor, a jurisdiction that does not allow third-party beneficiaries to enforce a contract).

310. See, e.g., Abigail Lauren Perdue, For Love or Money: An Analysis of the Contractual Regulation of Reproductive Surrogacy, 27 J. Contemp. Health L. \& PoL'y 279, 286 (2011) ("Furthermore, the contract's enforceability could be challenged because, inter alia, the agreement is unconscionable, illegal, or void against public policy.").

311. See, e.g., Kimberlianne Podlas, Artistic License or Breach of Contract? Creator Liability for Deceptive or "Defective" Documentary Films and Television Programs, 33 LOY. L.A. ENT. L. REV. 67, 85 (2013) ("Fundamentally, a contract is an exchange of promises, consisting of an offer, acceptance, and consideration.").

312. Restatement (SECOND) OF CONTRACTS $§ 302$ (2007). 
a category of intended beneficiary for all potential adopters of the standard. Thus, accepting that the agreement is a valid contract and that potential licensees are the intended beneficiaries under the contract, there is a good legal basis for potential licensees bringing suit in court to enforce a FRAND commitment, whether they are SSO members or not. However, Lemley expresses concern that this broad interpretation of "intended beneficiary" as including nonmembers may be impermissible under contract law in the absence of explicit language in the FRAND commitment. ${ }^{313}$ An SSO can address this ambiguity by inserting language indicating that the FRAND commitment is intended to benefit all potential standard adopters, including nonmembers. If the Widget SSO adopted such language, the fact that Widgecom was not a member of the Widget SSO would clearly not prevent it from enforcing the FRAND commitment against parties who are otherwise bound by it.

Jurisdiction raises another potential conflict. As noted above, European courts may not be as receptive to third-party beneficiary arguments as U.S. courts. Faced with the inability of standard adopters to enforce the FRAND commitments as third-party beneficiaries, some SSOs may need to reconsider their current policies against getting involved in licensing disputes, because otherwise the parties that are the intended beneficiaries of FRAND commitments may not have the standing to enforce these commitments.

Problem $2 \mathrm{~b}$ of the hypothetical raises the issue of after-acquired patents. Assume that Gizmo Inc. promised in 2010 to license patents on FRAND terms to adopters of the Widget standard, back when the only relevant patent held by Gizmo Inc. was the five-inch Widget-1A patent. In 2011, Gizmo Inc. obtained Doodad LLC's patent on the Widget-3 technology. Assuming that the FRAND commitment applies equally to "core" essential and "noncore" essential patents, can Widgetech and Widgecom demand the ability to negotiate for a FRAND license to the Widget3 patent as well as the Widget-1 A patent? This question of after-acquired patents is another issue that an SSO could address in advance in its IPR policy.

Of all of the options that we consider in this Article, contract law is probably the best suited to address the problem of after-acquired patents. Contract terms that create an interest in after-acquired property are not new to the law: commercial contract law and the UCC already address the issue of interests in after-acquired property. ${ }^{314}$ Specifically, Article 9 of the UCC allows for the creation of security interests in after-acquired collateral, for example, if a small retail business obtained a loan from a bank, and in exchange for this loan, the business owner granted the bank a security interest in present and after-acquired inventory. ${ }^{315}$

Security interests and FRAND commitments are similar to each other in a number of ways. First, both are promises relating to something that may not exist

313. Lemley, supra note 19, at 1915. However, Lemley is arguing that it would be inconsistent with contract law to read a contract as making the public at large an intended third-party beneficiary. In the SSO context, the public is not the intended beneficiary. The class of intended beneficiary consists of potential implementers of the standard. If a member of the public was using the patent for a purpose other than to comply with the standard, the FRAND commitment would not apply.

314. U.C.C. § 9-204 (2001).

315. Id. 
yet, and these promises are being offered as consideration for something desirable. With security interests, the promise is that the entity that makes a loan will have protection in the event that the borrower defaults. ${ }^{316}$ When a patent owner enters into an agreement with an SSO to license its patent on FRAND terms, this is often as a condition of the patent's claims being adopted as part of the standard. The patents of mechanical devices are often not worth much on their own except as part of a larger product that relies on several technologies, but when a standard relies on a particular patent, that patent owner can then expect an increase in the demand for licenses.

Second, neither a security interest nor a FRAND commitment is a concrete thing, and neither would line up perfectly with contract law in the absence of specific provisions. If after-acquired collateral were not already an accepted premise in the law of secured transactions, loan terms allowing a lender to claim as yet undefined collateral might be argued as being vague and unenforceable under contract law. Similarly, a FRAND commitment to license as-yet-unacquired patents to undisclosed parties on undisclosed terms may lead to arguments from patent owners that the FRAND commitment is too vague to be an enforceable contract. This argument for unenforceability is likely to fail, because the modern rule of contract law permits parties to leave some terms subject to future determination, such as references to a "reasonable market price." 317

Analogizing FRAND commitments to security interests is instructive in another way as well. The after-acquired collateral provisions of Article 9 can be fairly viewed as a legislative approach to addressing a problem that was faced by commercial lenders prior to the enactment of Article 9. These provisions aided in the development of the commercial lending industry in the middle of the twentieth century. ${ }^{318}$ Thus, to the extent that the desire to apply FRAND commitments to after-acquired patents can be analogized to security interests, this analogy suggests that legislative intervention may be advisable, rather than pure reliance on common law approaches.

FRAND commitment transferability, however, remains problematic. Contract law focuses on mutual assent to contract terms, ${ }^{319}$ so in order for the FRAND commitment to apply to PatBuy, Inc., PatBuy would have to have agreed to be bound by this prior agreement. The current solution to the FRAND commitment transferability problem is for SSOs to address the transferability of the agreement in the initial contract with the patent owner. If the Widget SSO stated in its IPR policy that transfers must be made subject to the FRAND commitment, the focus would be on whether HF Gadget obtained the required consent to be bound.

316. See id. § 9-601 (describing a secured party's rights after debtor defaults).

317. See, e.g., id. § 2-305 (allowing contracts for sale even when the contract does not specify a price).

318. See Benjamin D. Beard, The Purchase Money Security Interest in Inventory: If It Does Not Float, It Must Be Dead!, 57 TenN. L. REV. 437, 463-65 (discussing the evolution of the acceptance of floating liens on present and after-acquired inventory).

319. See Danielle Kie Hart, Contract Formation and the Entrenchment of Power, 41 LOY. U. CHI. L.J. 175, 199 (2009) ("With the exception of reliance and restitution, the rest of contract law is implicated only if a 'traditional contract,' that is, one formed via mutual assent and consideration, exists." (internal footnotes omitted)). 
However, it is unclear what the proper recourse would be if a patent owner violated the terms of the SSO's bylaws by failing to secure the assignee's consent to be bound by the agreement. There may be a possibility of the implementers or the SSO holding the original patent owner liable for failure to abide by these terms, but even if damages could be obtained from the original patent owner, the implementers could not likely use the previous patent owner's breach to compel a license from the current owner. In Part I.F.1, we discuss the differing approaches of four SSOs to the issue of FRAND commitment transferability.

With the exception of the patent transfer issue, the four main issues that we raised in the Widget hypothetical could be resolved through contract language as long as the language was not excessively broad or unreasonable. SSOs could impose a requirement that SEPs be transferred subject to the FRAND commitment made by the prior owner, but a breach of this term by the assignor likely could not be held against the assignee. The SSO could also make it explicit that the FRAND commitment is a promise to license on FRAND terms to all adopters of the standard, not just adopters who are also members of the SSO. The SSO could also include a provision addressing the after-acquired problem, explicitly stating that the FRAND commitment also applied to SEPs that the agreeing party obtained after entering into the agreement. Finally, the SSO could clarify whether the term "standard essential patent" includes core essential patents, noncore essential patents, and commercially essential patents. If the SSO considers commercially essential patents to be SEPs, the SSO should further clarify whether it is adopting a broad, intermediate, or narrow definition of commercial essentiality.

But to what end? Recent analysis of FRAND commitments has treated the commitment as a kind of affirmative defense to infringement, limiting the remedies available to the patent owner. ${ }^{320}$ Thus, in Part IV, we examine the options that a court might consider when determining the appropriate remedy for infringement of an SEP. For the purposes of this Part, we note that the typical contract damages of expectation and reliance damages are likely to be difficult to calculate in the standards context, and even if a value was determined, pure money damages are likely to be less attractive than requiring the patent owner to grant a license permitting the contract beneficiary to manufacture a product and compete in the relevant market.

\section{d. Applying Detrimental Reliance to the FRAND Problems}

Sometimes, the law of formal contracts will not be effective. While the third-party beneficiary doctrine may protect standard adopters as the intended beneficiaries of a FRAND commitment, and the law of security interests provides helpful guidance for dealing with after-acquired patents, there are still gaps that formal contract law does not fill. For that reason, scholars like Lemley, Merges, and Kuhn have suggested turning to an estoppel argument to permit standard adopters to argue that they relied to their detriment on the patent owner's assertion

320. E.g., In re Innovatio IP Ventures, LLC, 921 F. Supp. 2d 903, 915-16 (N.D. Ill. 2013) (noting that a FRAND obligation may provide defenses that limit available remedies). 
that it would license on FRAND terms. ${ }^{321}$ A theory of detrimental reliance would focus on whether a specific agreement is binding against other entities outside the four corners of the agreement because of the expectation that the agreement creates for third parties. ${ }^{322}$ Contreras suggests that a detrimental reliance theory would be more helpful than formal contract theory when addressing FRAND commitment issues. ${ }^{323}$

Detrimental reliance is often discussed in the context of implied licenses and equitable estoppel defenses in patent law, ${ }^{324}$ but for the purposes of this Part, we are viewing detrimental reliance as an alternative to formal contract law. A detrimental reliance theory is likely to be more helpful than a formal contract theory in the case of patent transfers. Under formal contract law, the FRAND commitment would likely have to be accepted by the assignee for the agreement to be binding after the patent is transferred. On the other hand, a detrimental reliance theory is focused on the standard adopter's investments in reliance on the availability of a license. ${ }^{325} \mathrm{In}$ this situation, the standard adopter is fully willing to pay the cost of licensing, but in the interest of competition, may feel pressured to adopt the standard prior to solidifying a licensing agreement.

However, detrimental reliance is not perfect either. First, as Mueller notes, it may not be reasonable for parties who are not members of the SSO to rely on a patent owner's promise to the $\mathrm{SSO}^{326}$ In terms of addressing the problem of whether the FRAND commitment binds subsequent owners, detrimental reliance may suffer from the same drawbacks as equitable estoppel and implied licenses as defenses under patent law because the assignee may have made no representations concerning licensing. And even if the detrimental reliance theory is effective at addressing some SEP licensing problems, it is unclear if the same theory could apply to noncore essential patents, commercially essential patents, or after-acquired patents. Detrimental reliance is also not likely to assist in the case of after-acquired patents unless the previous owner made a FRAND commitment to the same SSO concerning that patent.

Ultimately, neither formal contract law nor detrimental reliance effectively addresses all of the primary problems that threaten to arise in the context of FRAND commitments. Contract law may assist with several of the problems, but it contains no legal tools to enable a FRAND commitment to be binding against subsequent assignees in the absence of the assignee giving explicit consent to be bound. Considering how often patents are transferred, this threatens to reduce FRAND commitments to a meaningless formality that can be enforced against no

321. E.g., Lemley, supra note 19, at 1915-16; Merges \& Kuhn, supra note 30, at 4.

322. See Lemley, supra note 19, at 1920; Merges \& Kuhn, supra note 30, at 46-47.

323. Jorge L. Contreras, Patent Pledges (Working Paper, Aug. 15, 2013), available at http://papers.ssrn.com/sol3/papers.cfm?abstract_id=2309023.

324. E.g., Janice M. Mueller, Patent Misuse Through the Capture of Industry Standards, 17 BERKELEY TECH. L.J. 623, 659 (2002).

325. See supra text accompanying note 164 (discussing the related principle of equitable estoppel under patent law).

326. Mueller, supra note 324, at 659 ("Third parties who did not participate in the standards-setting activity and had no contact with the patentee would be unable to establish detrimental reliance.”). 
one. At the most basic level of contract law, it does not seem like this would be a fair reading of the FRAND commitment, because an SSO would likely not require members to make a commitment that the SSO did not intend to have legal force. But the nature of contract law also would prevent a FRAND commitment from transferring to a subsequent assignee unless the assignee agrees to be bound by the commitment. During the development of a standard, if an SSO member refuses to make a FRAND commitment, the SSO will typically adopt an alternative technology and bypass the technology of the refusing member. An SSO that has already adopted a standard and now faces an assignee that refuses to commit to FRAND licensing has encountered a much bigger problem, because an entire industry may now be locked in to the version of the standard that includes the assignee's patent.

Thus, we propose a fourth option for analyzing FRAND commitment problems: examining these problems through the lens of property law and servitudes, based on the theory that the FRAND commitment creates an encumbrance on the patent.

\section{Property}

As discussed above, there are a number of fundamental flaws with relying on patent law, antitrust law, and contract law to address problems that might occur in the standards context. A final body of law that could potentially apply to these situations, though there has been no discussion of this option up to this point, is property law. While the question of FRAND commitments has not been addressed using a property theory, there is growing literature asserting that intellectual property licenses are analogous to traditional property rights. ${ }^{327}$ These arguments typically run counter to the traditional view of licensing as creating only a contract promising that the licensor will not sue the licensee for the licensee's use of the intellectual property. ${ }^{328}$ In the following Part, we argue that, like licenses, commitments to license have traits that resemble property interests. Both licenses and commitments to license create an encumbrance on the intellectual property owner's right to exclude. The biggest difference between the two is the identity of the beneficiary. With licenses, it is clear who is favored by that encumbrance. With commitments to license, on the other hand, the encumbrance is the IP owner's commitment to be open to future license negotiations and to not refuse to negotiate with parties entitled to seek a license.

327. See generally Christopher M. Newman, A License Is Not a "Contract Not To Sue": Disentangling Property and Contract in the Law of Copyright Licenses, 98 IowA L. REV. 1101 (2013) (suggesting that licenses are a property interest); Molly Shaffer Van Houweling, The New Servitudes, 96 GEO. L.J. 885 (2008) (comparing modern licensing practices to servitudes).

328. See, e.g., Spindelfabrik Suessen-Schurr Stahlecker \& Grill GmbH v. Schubert \& Salzer Maschinenfabrik Aktiengesellschaft, 829 F.2d 1075, 1081 (Fed. Cir. 1987) ("As a threshold matter, a patent license agreement is in essence nothing more than a promise by the licensor not to sue the licensee."); Mark R. Patterson, Must Licenses Be Contracts? Consent and Notice in Intellectual Property, 40 FLA. ST. U. L. REV. 105, 109 (2012) ("This Article argues that the weight of judicial authority and sound policy support a contractual approach to license formation."). 
In Part III, we examine the possibility that the law of real property can offer some useful analogies to buttress arguments that FRAND commitments "run with the patent." For example, by treating FRAND commitments like servitudes, the main issue would become whether the assignee had notice of the agreement, rather than whether the predecessor in interest secured a commitment from the assignee to be bound by the agreement. It is to this new characterization of FRAND commitments that we now turn.

\section{FRAND COMMITMENTS AND THE LAW OF TANGIBLE PROPERTY}

"No one can doubt, that the convention for the distinction of property, and for the stability of possession, is of all circumstances the most necessary to the establishment of human society . ...,329

Patents have aspects that resemble several different areas of law. Under U.S. patent law, patents are deemed to "have the attributes of personal property." 330 When a patent owner grants a license to another party, the license is often analyzed as a contract. ${ }^{331}$ Patent law also has flavors of tort law, with patent infringement claims being based on principles of strict liability. ${ }^{332}$ We noted above that there is currently a debate about the extent to which patent licenses should be viewed as property interests instead of purely as creations of contract. In our view, this argument has merit, but we view the property and contract traits of patent law as being interrelated, rather than a strict either/or matter. Contracts and property are not as independent of each other as the first year law school curriculum might suggest. As Newman observes, some typical contract language, like "title shall pass upon delivery," focuses on legal consequences under property law and is impossible to breach. ${ }^{333}$

A FRAND commitment is an enforceable contract, but it is also an enforceable contract that pertains to the treatment of intellectual property. While patents are statutorily decreed to have the attributes of personal property, ${ }^{334}$ Mossoff argues that historically, patents were treated as having attributes of both real property and personal property. ${ }^{335}$ It therefore might be instructive to analogize to real property in the case of standards and patent transfers. With real property, promises to do or not do something with the property may "run with the land." ${ }^{336}$ In light of the importance

329. David Hume, A Treatise of Human Nature 491 (L.A. Selby-Bigge ed., Oxford Univ. Press 1978) (1739).

330. 35 U.S.C. $\$ 261(2006)$.

331. ProCD, Inc. v. Zeidenberg, 86 F.3d 1447, 1450 (7th Cir. 1996) ("[W]e treat the licenses as ordinary contracts ....."); H. Justin Pace, Note, Anti-Assignment Provisions, Copyright Licenses, and Intra-Group Mergers: The Effect of Cincom v. Novelis, 9 Nw. J. TECH. \& InTELl. PROP. 263, 267 (2010) ("Copyright and patent licenses are contracts and as such are interpreted according to state law." (emphasis in original)).

332. Siddharth Khanijou, Patent Inequity?: Rethinking the Application of Strict Liability to Patent Law in the Nanotechnology Era, 12 J. TECH. L. \& POL'Y 179, 197 (2007).

333. Newman, supra note 327, at 1129.

334. 35 U.S.C. $\S 261$.

335. Mossoff, supra note 204, at 719.

336. See Lawrence Berger, Promises Respecting the Use of Land, 55 MinN. L. ReV. 167, 169 (1970) (discussing the importance of obligations running with the land). 
of FRAND commitments for facilitating the adoption of new technology standards, we view it as reasonable to argue that FRAND commitments should "run with the patent."

Ultimately, however, intellectual property is a sui generis construction, ${ }^{337}$ and direct analogies may not always be accurate. While drawing comparisons to other types of property may be helpful, Menell warns there are still important distinctions between patents and tangible property. ${ }^{338}$ For instance, unlike land or personal property, a patent is nonrivalrous and thus can be used by many people at once. This fundamental distinction contributes to the difference between the more formalistic approaches to tangible property and the more flexible approaches to intellectual property. ${ }^{339}$ However, some property rights scholars argue that intellectual property rights share the same functionalist policy concerns as tangible property rights. ${ }^{340}$ Mossoff found that an examination of legal history supports this view and argues that nineteenth century patent law in the United States reflects a judicial approach to patents that was much more similar to property law approaches than modern theorists believe. $^{341}$

\section{A. Analyzing a Property Approach to FRAND Commitments}

Because we view a FRAND commitment as a prelude to a license, we begin this Part with a discussion of how property theory has been applied to licenses, before treading into more theoretical grounds with discussions of the property-contract interface, informed by insights from the work of Hohfeld and more contemporary scholars like Merrill and Smith.

\section{Licenses as Property}

Newman, a proponent of the property theory of IP licenses, acknowledges that licenses have traits of a contract and are often granted as part of a contractual relationship, but also observes that a license shapes the allocation of resources, which is a fundamental concern of property. ${ }^{342}$ Some argue that a license should be viewed as a contract, not a property interest, based on the idea that a license is a "covenant not to sue." ${ }^{343}$ As Newman critically observes, this argument, at its core, relies on a view

337. See Mark A. Lemley, Property, Intellectual Property, and Free Riding, 83 Tex. L. REV. 1031, 1074-75 (2005) (criticizing analogies to other areas of law because intellectual property law has unique traits).

338. Menell, supra note 22, at 739 (warning that "extrapolating from real property law to intellectual property law overlooks important distinctions between the underlying resources at issue.").

339. Id. at 751 (arguing that the absolutist view of the property rights movement does not align with the IP rights system).

340. See Mossoff, supra note 204, at 707 (discussing the position of Richard Epstein).

341. Id. at 711-12 (noting that patent exhaustion doctrine is derived from traditional property law).

342. Newman, supra note 327, at 1108-09.

343. See Jennifer Ying, The Plain Meaning of Section 365(c): The Tension Between Bankruptcy and Patent Law in Patent Licensing, 158 U. PA. L. REV. 1225, 1260 (2010) (describing a patent license as "merely a covenant not to sue for infringement"). 
that what the licensee is doing constitutes trespass or infringement and is only permitted because the licensor made a promise beforehand not to sue the licensee. ${ }^{344}$ After all, if the action of the licensee was not still a violation of the licensor's rights, a promise not to sue would be unnecessary. Thus, asserting that a license is a promise not to sue implicitly assumes that a license contract does not create a privilege to use the licensed property, ${ }^{345}$ which is not logically sound. Newman argues that this approach is also not reconcilable with the aspect of copyright law that allows multiple co-owners the power to grant nonexclusive licenses without obtaining the consent of the other owners, ${ }^{346}$ or with the fact that revocable licenses can be created without contract formalities. ${ }^{347}$

The idea that a patent license is a "covenant not to sue" is a very old one that represents the view of federal courts for over a century. ${ }^{348}$ However, this does not mean that courts view patent licenses as purely creatures of contract. This position is based on an even older view of patents themselves: that obtaining a patent does not give the owner a right to practice the invention, but instead gives the owner a right to exclude everyone else from practicing the invention without the owner's permission. ${ }^{349}$ The patent is thus a "right against the world," like other property rights. ${ }^{350}$ An assignment of a patent involves a full transfer of this right, whereas a patent license involves transfer of a lesser interest. ${ }^{351}$ As Mossoff's research shows, patent case law in the United States has long recognized that patentees could convey lesser interests in the patent and that the recipient of these lesser interests may be liable if they exceed the scope of these interests. ${ }^{352}$ Newman observes that as a legal instrument that permits use of a resource in a way that would otherwise be a trespass, a license can thus be understood as a use privilege similar to other recognized property interests. ${ }^{353}$ Thus, even if patent licenses are viewed as covenants not to sue, this does not prevent the license from also being a property interest.

This Part extends this reasoning to FRAND commitments, arguing that FRAND commitments can be characterized as contractually created property interests in covered patents. We noted above that a patent license may be viewed as creating a

344. Newman, supra note 327 , at 1130.

345. Id.

346. Id. at 1131 .

347. Id. at 1142 .

348. Henry v. A.B. Dick Co., 224 U.S. 1, 24 (1912) (“As a license passes no interest in the monopoly, it has been described as a mere waiver of the right to sue by the patentee."); see also De Forest Radio Tel. \& Tel. Co. v. United States, 273 U.S. 236, 242 (1926) (affirming the above quoted language of Henry).

349. Bloomer v. McQuewan, 55 U.S. (14 How.) 539, 549 (1852) ("The franchise which the patent grants, consists altogether in the right to exclude every one from making, using, or vending the thing patented, without the permission of the patentee. This is all that he obtains by the patent.").

350. See Lee Kovarsky, Note, Tolls on the Information Superhighway: Entitlement Defaults for Clickstream Data, 89 VA. L. REV. 1037, 1079 (2003) (noting that when property law applies, the right is good against the whole world).

351. Mossoff, supra note 204, at 714.

352. Id. at 715 .

353. Newman, supra note 327 , at 1158-59. 
use privilege. However, a FRAND commitment cannot be said to do the same thing. On the other hand, a FRAND commitment could fairly be categorized as creating a negotiation right to benefit the adopters of the standard, with the patent owner retaining a duty to not refuse to negotiate. A FRAND commitment is not a license, but when a patent owner makes a FRAND commitment, we argue that this acts as a conditional covenant not to sue, whereby the patent owner promises to not sue standard implementers for infringement unless and until good faith attempts at negotiation fail.

\section{Hohfeldian Approaches to Jural Relations and the Intersection of Property and} Contract

Even though the career of Wesley Newcomb Hohfeld was short, he nonetheless made lasting contributions to the way that the language and philosophy of law are understood. Hohfeld's 1913 article, Some Fundamental Legal Conceptions as Applied in Judicial Reasoning, sets forth a helpful guide for describing legal relations. ${ }^{354}$ This hundred-year-old article is so widely read and referenced that it landed a spot at number fifty in Shapiro and Pearse's recent study ranking the one hundred most-cited law review articles. ${ }^{355}$

In his article, Hohfeld abandons an attempt at formally defining each term and focuses on defining the terms as they relate to each other, emphasizing the relations between the concepts of rights, no-rights, privileges, powers, immunities, duties, disabilities, and liabilities. ${ }^{356}$ Hohfeld noted that the term "right" is often used broadly to refer to privileges, powers, and immunities, but he emphasizes that these ideas should be understood separately. ${ }^{357}$ Hohfeld pairs these eight concepts and indicates which are jural opposites of each other, and which are jural correlatives of each other. ${ }^{358}$ The jural opposite pairs are rights and no-rights, privilege and duty, power and disability, and immunity and liability; the jural correlative pairs are rights and duty, privilege and no-right, power and liability, and immunity and disability. ${ }^{359}$

To say that rights and duties are jural correlatives of each other is to say that invading a right inherently involves the violation of a duty. ${ }^{360}$ Thus, a patent that gives its owner a right of exclusivity imposes on all others a duty to not infringe the patent. To say that duty and privilege are jural opposites of each other is to say that the privilege of doing a specific action negates the duty to not do a specific action. ${ }^{361}$ If a patent licensee has a privilege to use the licensed patent, this indicates that the licensee has no duty to refrain from using the patent. Rights and privileges

354. Wesley Newcomb Hohfeld, Some Fundamental Legal Conceptions as Applied in Judicial Reasoning, 23 YALE L.J. 16, 30 (1913).

355. Fred R. Shapiro \& Michelle Pearse, The Most-Cited Law Review Articles of All Time, 110 Mich. L. REV. 1483, 1490 (2012).

356. Hohfeld, supra note 354 , at 30.

357. Id.

358. Id.

359. Id.

360. Id. at 32 .

361. Id. 
are also related, in the sense that a right indicates an affirmative claim against another, whereas a privilege indicates "freedom from the right or claim of another." ${ }^{362}$ Analogously, the word power is generally used to indicate that one person has affirmative control of a particular legal relation, whereas immunity indicates that one person has freedom from the control that another might otherwise exercise over a particular legal relation. ${ }^{363}$ Yaniv Heled notes, however, that having immunity from the power of another does not imply that a right to act has been conferred. ${ }^{364}$

Newman notes that under traditional property law, a property owner can create use privileges, such as easements or licenses, and bestow these use privileges on another while otherwise retaining full ownership of the property. ${ }^{365}$ If $A$ gives a use privilege to $B$ that allows $B$ to cross $A$ 's land, this suggests that $A$ has no right to interfere with $B$ 's exercise of his use privilege. Use privileges can either be revocable or irrevocable. ${ }^{366}$ Let us again assume that $A$ grants a use privilege to $B$. If $A$ declares that $B$ 's use privilege is irrevocable, this will generally mean that if $A$ assigns his full interest in the property to $C$, then $C$ will have no right to interfere with $B$ 's existing use privilege. ${ }^{367}$ However, use privileges are likely not irrevocable unless the property owner states that they are. ${ }^{368}$ In Hohfeldian terms, an irrevocable license may be understood as granting the licensee immunity from revocation, ${ }^{369}$ which is the same thing as saying that the licensor has no power to revoke the license. ${ }^{370}$

By the license itself being a use privilege, this suggests that the licensee obtains a privilege to use the property, whereas the property owner has a no-right and cannot prevent the use by the licensee. ${ }^{371}$ An irrevocable patent license thus creates a use privilege, and the patent owner has no right to interfere with the licensee's use. The FRAND commitment may be understood as imposing on the patent owner a duty to negotiate in good faith, ${ }^{372}$ and through Hohfeldian analysis, this means that there is a correlative right to good faith negotiation that is held by the potential licensee. Thus, an irrevocable license creates a use privilege with which the patent

362. Id. at 55 .

363. Id.

364. See Yaniv Heled, Regulatory Competitive Immunities-An Emerging Class of Intellectual Property, at 24 (Dec. 2012) (unpublished manuscript) (on file with authors).

365. Newman, supra note 327 , at 1120 (noting the existence of use privileges in property law).

366. Id. at 1124 .

367. Id. at 1123 .

368. Id. at 1147 .

369. Id. at 1115 .

370. Hohfeld, supra note 354, at 55.

371. Id. at 32 .

372. Apple, Inc. v. Samsung Electronics Co., No. 11-CV-01846, 2012 WL $1672493 * 12$ (N.D. Cal. May 14, 2012) (noting that the parties explicitly acknowledged that the FRAND commitment creates a "duty to negotiate"); see also Realtek Semiconductor Corp. v. LSI Corp., No. C-12-03451RMW, 2012 WL $4845628 * 4$ (N.D. Cal. Oct. 10, 2012) (indicating that a bad faith initial offer may violate the duty of good faith); Microsoft Corp. v. Motorola, Inc., 864 F. Supp. 2d 1023, 1038 (W.D. Wash. 2012) (noting that negotiations are subject to an implied duty of good faith and fair dealing). 
owner has no right to interfere, and a FRAND commitment bestows on the standard adopter a right to negotiate that the patent owner has a duty to recognize.

Having established that the FRAND commitment creates a right for the benefit of the potential licensee, we turn next to the characterization of this right. In a later article, Hohfeld recognizes two categories of rights: in rem and in personam. ${ }^{373} \mathrm{~A}$ conclusion that FRAND commitments create an in personam right would be consistent with a conclusion that contract law should govern, while a conclusion that FRAND commitments create an in rem right would be consistent with a conclusion that property law should govern.

Hohfeld refers to in personam rights as "paucital rights" and to in rem rights as "multital rights." ${ }^{374}$ Merrill and Smith provide a very helpful and detailed analysis of Hohfeld's discussion of in rem and in personam rights and the overlap between these ideas in the modern context. ${ }^{375}$ Rights in rem may pertain to tangible objects, but they may also pertain to intangibles, like patents or a right to privacy. ${ }^{376}$ Rights that are in rem are typically viewed as being binding against the rest of the world, creating negative obligations that prevent everyone else from taking particular actions. ${ }^{377}$ Rights that are in personam are typically viewed as being binding against only definite parties, creating affirmative obligations that require the specified parties to take affirmative actions. ${ }^{378}$ In rem rights are generally associated with a limited number of forms that the rights can take, while in personam rights are associated with flexibility and default rules. ${ }^{379}$ In personam rights impose a large informational burden on a small class of actors with very little effect on third parties, while the exclusion strategy of in rem rights imposes the informational burden on a large, undefined class. ${ }^{380}$

To mitigate the harmful effects of the informational burdens, Merrill and Smith note that the law typically uses either a notice strategy or a protection strategy. ${ }^{381} \mathrm{~A}$ notice strategy focuses on facilitating the generation of information about the relation, while a protection strategy involves specific legal interventions, like default rules, designed to favor the uninformed party. ${ }^{382}$ Merrill and Smith suggest that notice and protection strategies could be permitted to overlap, such as in the case of a notice strategy that includes a penalty default rule favoring the nontransferring party if there is a failure to disclose. ${ }^{383}$ Merrill and Smith's analysis suggests that notice strategies would be appropriate when the information can be

373. Wesley Newcomb Hohfeld, Fundamental Legal Conceptions as Applied in Judicial Reasoning, 26 YALE L.J. 710, 718 (1917).

374. Id. at 716 .

375. Merrill \& Smith, supra note 96 , at 780-83.

376. Hohfeld, supra note 373, at 733-34.

377. Merrill \& Smith, supra note 96, at 776-77, 788.

378. Id. at 776-77, 789 .

379. Id. at 778 .

380. Id. at 790 .

381. Id. at 805 .

382. Id.

383. Id. at 808 . 
produced in a cost effective manner, while protection strategies would be appropriate when information production would not be cost effective. ${ }^{384}$

Notice and protection strategies can already be seen in the private governance structures of SSOs. Many SSOs, for example, require members to disclose essential patents that the members own. ${ }^{385}$ The disclosure rule acts as a notice strategy that aims to put adopters on notice of the rights of others. Some SSOs also make records of FRAND commitments publicly available. ${ }^{386}$ In the case of IEEE-SA, the member's Letter of Assurance concerning IP rights is posted on the organization's website, thus serving a notice function. ${ }^{387}$ Some SSOs, such as VITA, go further and specify that a member who fails to disclose an SEP would then be required to license that patent on a FRAND-RF basis. ${ }^{388}$ This type of FRAND-RF rule could be fairly characterized as a protection strategy that favors the party who has an informational disadvantage.

FRAND commitments thus can be addressed through a combination of notice and protection strategies. As we examine below, there are many examples of instances where FRAND commitments behave like contract interests and property interests. This overlap is consistent with the theories of Merrill and Smith, who observe that some legal situations can be purely in rem, others purely in personam, but that some demonstrate a mixture of the two concepts. ${ }^{389}$ Merrill and Smith thus propose that there are four primary categories of rights: pure paucital rights, compound-paucital rights, quasi-multital rights, and pure multital rights. ${ }^{390}$ As discussed above, in personam, or paucital rights, avail against singular identified persons, while in rem, or multital rights, avail against numerous unidentified persons.

These two factors, numerosity and identification, also combine into two other possible intermediate characterizations. Merrill and Smith view compound-paucital rights as availing against numerous identified persons, whereas quasi-multital rights avail against singular, unidentified persons. ${ }^{391}$ According to Merrill and Smith, an example of a compound-paucital situation is a standard form contract, where the possible people bound by the agreement are numerous and definite; and an example of a quasi-multital situation is an assignment of interest, where the possible people bound by the agreement are nonnumerous but indefinite. ${ }^{392}$ Even though "in personam" and "contract" are not synonyms, nor are "in rem" and "property" synonyms, for our purposes, we consider compound-paucital rights to be "contract with property traits" and quasi-multital rights to be "property with contract traits."

384. Id. at 805-06.

385. E.g., EuRoPEAn TELECOMMS. STANDARdS InST., supra note 54.

386. Records of IEEE Standards-Related Patent Letters of Assurance, INST. OF ELEC. \&

ELECS. ENG'RS STANDARDS ASS'N, http://standards.ieee.org/about/sasb/patcom/patents.html.

387. Id.

388. VITA STANDARDS ORG., supra note 81.

389. Merrill \& Smith, supra note 96, at 777.

390. Id. at 778 .

391. Id.

392. Id. at 785 . 
Merrill and Smith's characterization of intermediate rights in the propertycontract interface has proved very important in developing our own theory for characterizing FRAND commitments, which we quickly recognized were creations neither purely of contract nor purely of property. In the study by Merrill and Smith, the authors examined four separate areas of law that cannot be clearly characterized as purely in rem or purely in personam: bailments, landlord-tenant law, security interests, and trusts. ${ }^{393}$ In our view, the treatment of patents in the standard-setting context is a fifth area where the rights cannot be characterized as solely in rem or solely in personam. When a patent is declared essential to a standard, the patent owner has in rem rights which the law must protect against a large and indefinite class of potential infringers, and all of the adopters of the standards have a duty to respect the IP rights of those who own SEPs. When a patent owner enters into a license with a standard adopter, this creates an in personam relation with affirmative obligations exchanged between defined parties.

We argue that a FRAND commitment also has traits of both property and contract. By promising to license SEPs on FRAND terms to eligible parties, a patent owner takes on specific duties with regard to a large, undefined class of standards adopters. In other words, the right created by the FRAND commitment avails against a singular, identified person. This makes the FRAND commitment seem like an instrument that creates in personam rights. But unlike a typical in personam situation, where both sides of the agreement are identified, FRAND commitments involve a singular, identified party who has a duty under the commitment and a numerous class of unidentified parties who have a right under the commitment.

This facet prevents FRAND commitments from fitting easily into either Hohfeld's primary categories or Merrill and Smith's intermediate categories. Merrill and Smith arrive at their intermediate categories by characterizing Hohfeld's approach as focusing on the numerosity of duty holders and the definiteness of duty holders. ${ }^{394}$ It may thus be helpful to add two more categories to the theoretical approach of Merrill and Smith: numerosity and definiteness of the right holders. In a typical in rem relation, the right holder will be nonnumerous and definite, while the duty holder will be numerous and indefinite. A FRAND commitment is a reversal of this, with a nonnumerous and definite duty holder, and a numerous and indefinite class of right holders. We argue that this gives the FRAND commitment itself some qualities of both property and contract.

The intermediate nature of the FRAND commitment is especially apparent when a patent, which is subject to a FRAND commitment, is then transferred. In that case, the patent owner against whom these rights may be asserted is unknown, giving the transfer traits of a quasi-multital relation. The class of potential licensees still has a negotiation right, but the right now avails against a singular, unidentified person. To protect FRAND commitments when patents are transferred, either a notice or protection strategy may be appropriate. In the case of patent transfers, a notice regime that provides for mandatory recordation of assignments might be

393. Id. at 814 .

394. Id. at 785 . 
effective at reducing the informational burden when the potential licensees must determine the current owner of an essential patent.

In this Part, we have taken the view of a license as a use privilege and extended it to conclude that a FRAND commitment is a negotiation right. This right creates a corresponding duty to not interfere with the authorized activity. The FRAND commitment can either be characterized as a contract with property traits or as property with contract traits. Building on the theories of Hohfeld and the work of Merrill and Smith, we argue that under some circumstances it is appropriate to take a property-based approach to FRAND commitments and patent transfer issues in the standards context. As this Part shows, viewing FRAND commitments through the lens of property interests is part of a logical progression building on work concerning the intersection of property and contract. Having established the theoretical underpinnings, we turn now to the more concrete application of the law of servitudes.

\section{B. Analogizing to the Law of Servitudes}

There are several defined interests in real property law, including fee simple estates, life estates, and leaseholds. ${ }^{395}$ In addition to these, parties can make land use arrangements based on private agreements, and these arrangements can result in the creation of servitudes. ${ }^{396}$ Servitudes are nonpossessory property interests by which the holder gains a right in an asset, and servitudes are generally enforceable against successors in interest, provided the successor has notice of the servitude. ${ }^{397}$

There are four general categories of servitudes: easements, profits, licenses, and covenants. ${ }^{398}$ Covenants can either be real covenants or equitable servitudes, depending on how they are enforced, but the Restatement (Third) of Property: Servitudes indicates that there is no longer a significant difference between real covenants and equitable servitudes. ${ }^{399}$ Equitable servitudes arose under English common law. Analysis often traces their development to Tulk v. Moxhay, ${ }^{400}$ an 1848 case concerning an encumbrance on a lot in Leicester Square, where the Chancery Court concluded that the prior restrictions ran with the land, provided the subsequent purchaser had notice of these restrictions. ${ }^{401}$

A servitude can be characterized as having a benefited party and a burdened party. ${ }^{402}$ For the benefit to run under the common law test, the party had to

395. D. Benjamin Barros, Toward a Model Law of Estates and Future Interests, 66 WASH. \& LEE L. REV. 3, 8 (2009) (listing types of estates in American property law).

396. Susan F. French, Servitudes Reform and the New Restatement of Property: Creation Doctrines and Structural Simplification, 73 CoRnell L. REV. 928, 928 (1988) ("By using servitudes, land owners can make permanent changes in the default allocations of rights and obligations to their land.").

397. Van Houweling, supra note 327, at 891-92.

398. French, supra note 396, at 933 (listing the five primary types of servitudes, with real covenants and equitable servitudes listed separately).

399. See Restatement (ThiRd) of Prop.: Servitudes $\S 1$ Introductory Note (2000).

400. (1848) 41 Eng. Rep. 1143.

401. Id. at 1144; see also, e.g., Van Houweling, supra note 327, at 895.

402. See Berger, supra note 336, at 169-70 (discussing the concepts of property being benefited and burdened by a covenant). 
establish intent that the benefit would run to successors and that the agreement "touche[d] and concern[ed]" the land. ${ }^{403}$ For the burden to run, the party had to establish intent that the burden would run, that the agreement "touched and concerned" the land, and that the burdened party was on notice of the interest. ${ }^{404}$ Under the traditional rule for whether an agreement touches and concerns the land, such a promise would need to relate to the use of the land. ${ }^{405}$ However, the current Restatement discards the concept of "touch and concern," instead saying that servitudes are valid unless illegal, unconstitutional, or contrary to public policy. ${ }^{406}$

In our view, it is fairly uncontroversial to conclude that a FRAND commitment relates to the use of the patent. A FRAND commitment that leads to a license clearly relates to the benefited licensee's use of the patent. Similarly, the burden created by a FRAND commitment also relates to the use of the patent, because the FRAND commitment restricts the owner's ability to exclude others from practicing the invention. As discussed above, using the patent to exclude others from practicing the invention is a fundamental right of patent ownership. ${ }^{407}$ Thus, a FRAND commitment touches and concerns the patent, so even if a court applies the common law "touch and concern" test, rather than the Restatement's less restrictive standard, a FRAND commitment will satisfy the analysis.

For a FRAND commitment to be a valid servitude that will run with the patent, the assignee must also have notice of the FRAND commitment. This is another aspect that we think will prove to be uncontroversial. Standards documents are publicly available, and many SSOs also make FRAND commitments publicly available. ${ }^{408}$ Professionals who work in the ICT industries, especially those whose work implicates standards, will likely know about these standards and commitments because of their work. Because the issues here will primarily relate to publicly available standards, the notice requirement will be quite easily satisfied. Thus, if the patent is assigned to an entity that is a participant in the market for the products that rely on the patent, the assignee should be held to have notice of the FRAND commitment and the corresponding servitude.

The primary hurdle to analogizing to servitudes is that patents are treated as having the attributes of personal property, and servitudes on personal property are generally disfavored in the law, ${ }^{409}$ though Van Houweling argues that such

403. Id. at 173 (discussing the requirement of clear intention); id. at 207 (discussing the touch and concern requirement).

404. John Walliser, Conservation Servitudes, 13 J. NAT. Resources \& EnVTL. L. 47, 6670 (1997) (discussing notice as an equitable concept in the context of equitable servitudes).

405. Berger, supra note 336, at 210 (citing traditional formulations of the touch and concern requirement).

406. Restatement (Third) of Prop.: Servitudes $\S 3.1$ (2000). However, not all states have adopted the Restatement's approach. See Christopher D. McEachran, Sometimes Jumping on the Bandwagon is a Good Thing: An Analysis of North Carolina's Prohibition of Transfer Fee Covenants, 89 N.C. L. REV. 2201, 2221 (2011) (noting that North Carolina still applies the "touch and concern" standard).

407. See supra text accompanying notes 142 and 143.

408. See, e.g., Records of IEEE Standards-Related Patent Letters of Assurance, supra note 386.

409. Van Houweling, supra note 327, at 911 (noting the traditional hostility to chattel servitudes). 
servitudes may be permissible. ${ }^{410}$ Van Houweling notes that the law of servitudes has become more liberalized over the years, though this liberalization has primarily focused on servitudes in real property. ${ }^{411}$ When cases have considered servitudes on personal property, such as use restrictions, these cases have often been analyzed under competition law. ${ }^{412}$ There have also been use restriction cases focusing on IP rights that emphasized the first sale doctrine of copyright law and the exhaustion doctrine of patent law. ${ }^{413}$ Van Houweling's work focuses on use restrictions in items embodying IP to argue that the liberalization of servitudes should apply to personal property, specifically in the case of end user licensing agreements (EULAs). ${ }^{414} \mathrm{We}$ argue that Van Houweling's reasoning can also be extended to the negotiation rights that we propose are created by FRAND commitments. ${ }^{415}$ Compared to Van Houweling's argument for viewing EULAs as creating servitudes, the informational burden is likely less significant if FRAND commitments are viewed as creating a servitude-like interest that runs with the patent, because patent licensees and assignees arguably already have more incentive to read contract terms than individual purchasers of consumer software.

A servitude theory of FRAND commitments would also assist in addressing problems that might arise in the bankruptcy context. Under the Restatement (Third) of Property, servitudes are explicitly noted as not being dischargeable in bankruptcy. ${ }^{416}$ Viewing FRAND commitments as creating servitudes thus helps fill in a gap within bankruptcy law. Current bankruptcy law gives a licensee the power to elect to retain their license, ${ }^{417}$ but a FRAND commitment would likely be treated as less than a license unless the bankruptcy court explicitly states otherwise, as in the case of Nortel Networks. ${ }^{418}$ If the commitment is treated as creating a servitude, a FRAND commitment may more easily survive bankruptcy without extra steps being required of the bankruptcy court.

One last general advantage that should be noted for a servitude theory is the available remedy. By applying property law, the possibility of specific performance becomes viable for holders of the FRAND commitment-derived negotiation right. ${ }^{419}$

410. See id. at $888-89$.

411. Id. at 897 .

412. See id. at 908-09 (discussing cases about conditions placed on consumer products).

413. Id. at $910-12$.

414. Id. at 927 .

415. However, the IP servitudes that Van Houweling's work focused on are typically in the context of restrictions being placed on patented items that are sold, not the sale of patents themselves. Thus, while Van Houweling's work and her reasoning are instructive, the ideas behind patent exhaustion and the legality of conditional sales of patented items are relevant but are ultimately very different from the FRAND commitment issues. The importance of the transferability of FRAND commitments is a matter of symmetry and equity, not a matter of a property owner exercising continued control over the final product.

416. Restatement (Third) of Prop.: Servitudes $\S 7.9$ (2000).

417. 11 U.S.C. $\S 365(n)$ (2006).

418. In re Nortel Networks, Inc., No. 09-10138(KG), 2011 WL 4831218, at *9 (Bankr. D. Del. July 11, 2011).

419. Andrew Russell, Comment, The Tenth Anniversary of the Restatement (Third) of Property, Servitudes: A Progress Report, 42 U. ToL. L. REV. 753, 757 (2011) (discussing specific performance and equitable servitudes). 
This specific performance, however, does not require the patent owner to grant a license immediately, but rather requires the patent owner to give the holder of the negotiation right the opportunity to negotiate for a license that meets specified parameters. Thus, the remedy for a violation of the FRAND commitment is that the patent owner cannot play the patent holdout game. The fact that this specific performance will end with the holder of the negotiation right paying royalties to the patent holder does not matter in our view. It is often the case that servitudes in real property are acquired through purchase, sometimes through recurring payments. ${ }^{420}$

As we noted above, other areas of law do not seem to fully address some of the legal issues that are raised by FRAND commitments. If we analogize FRAND commitments to creating entitlements similar to those created under the law of servitudes, this greatly simplifies the issue of FRAND commitment transferability, though application of contract law principles for the other FRAND problems is likely still desirable.

\section{Servitudes and Transfers}

The most significant effect of adopting a servitude theory is that it would make it clear that, as a negotiation right that is partially in rem, FRAND commitments run with the patent. We begin this analysis with further discussion of benefits and burdens.

The law of servitudes focuses on benefits and burdens that are either appurtenant or in gross. To say that a burden or benefit is "appurtenant" means that it is "tied to ownership or occupancy of a particular unit or parcel of land." ${ }^{, 421}$ A burden or benefit that is "in gross," on the other hand, is not tied to such ownership or occupancy. ${ }^{422}$ The law of servitudes allows an appurtenant benefit or burden to transfer automatically with the property interest. ${ }^{423}$ For example, if a large parcel of land is subdivided into multiple lots, only one of which faces the main road, an appurtenant easement will likely be created by the landowners, who will then construct a driveway perpendicular to the main road to reach the back lots. This appurtenant easement would thus give access to the main road to owners of lots that are not adjacent to the road by creating a right of way across parcels owned by others. According to the Restatement (Third) of Property: Servitudes, benefits in gross were historically prohibited, as were benefits created in third parties. ${ }^{424}$ However, the rule set forth in the Restatement permits both of these and also allows for a burden to be appurtenant while a benefit is in gross. ${ }^{425}$

420. E.g., Riverwood Commercial Park, LLC v. Standard Oil Co., 2011 ND 95 ฯฯ 12-17, 797 N.W.2d 770, 776-78 (affirming the district court's conclusion that the existence of an annual payment was more in line with an easement than a license); Smith v. Huston, 251 S.W.3d 808, 815 (Tex. App. 2008) (discussing the creation of an access easement involving a $\$ 200$ per year charge).

421. Restatement (Third) of Prop.: Servitudes $\S 1.5(1)$ (2000).

422. Id. § 1.5(2).

423. Id. $\S 5.1$.

424. Id. $\S 2.6$ illus. 2 (providing an example of a burdened parcel of land).

425. Id. $\S 2.6 \mathrm{cmt}$. a. 
The issue of transferring the burden created by the FRAND commitment is almost completely resolved if we view the FRAND commitment as creating an appurtenant burden and a benefit in gross. Rather than requiring an active acceptance on the part of the assignee, as is likely the case under a formal contract law approach, an appurtenant burden can be binding on an assignee automatically, though the transfer of the burden will require the assignee to be on notice of the FRAND commitment. Because a property interest theory would rely on notice for a burden to transfer, rather than assent to the agreement as would be required for a contract to transfer, a servitude approach could resolve the problem of how to ensure that these agreements are binding against new assignees. If an assignee does not explicitly consent to the agreement, but has actual or constructive notice that he is acquiring an SEP, this property theory could help avoid "innocent purchaser" defenses raised by assignees that seek excessive royalties for newly acquired SEPs. In other words, provided there is constructive or actual notice, the agreement will "run with the patent" and prohibit excessive rent-seeking behaviors by new assignees. In the SEP context, notice could likely be inferred when the assignee is a participant in the market for products that implement the standard, because such standards are typically publicly available.

The nature of the interest created also gives the property theory an advantage over a detrimental reliance theory. With detrimental reliance, the interest is created based on the actions of the patent holder and the standard adopter. ${ }^{426}$ On the other hand, when a property interest is properly created, the interest will exist independently of the actions and perceptions of the patent holder and standard adopter. Thus, the burden for establishing a negotiation right is potentially easier to demonstrate with the property theory than it is when applying a detrimental reliance theory.

It is true that a patent is generally not being transferred when a FRAND commitment is made. But there is no property transfer when a servitude in real property is created either, just the creation of a use privilege. ${ }^{427}$ An illustration in the Restatement (Third) of Property: Servitudes provides a strong justification for our analogy to apply in this case. Illustration 2 of section 2.6 explains the current law of benefits in gross as follows:

As a condition of granting planning approval, the City of $\mathrm{X}$ requires Developer, the owner of Blackacre, to execute an agreement limiting the density of development on Blackacre. The agreement states that the burden shall run with Blackacre and the benefit shall be held by the City in gross. The agreement creates a servitude burdening Blackacre. The City of $\mathrm{X}$ holds the benefit in gross. ${ }^{428}$

This illustration offers an excellent analogy to the transfer of SEPs subject to FRAND commitments. Borrowing the above language, the FRAND commitment

426. See supra Part II.B.3.d.

427. See Lee Ann Fennell, Contracting Communities, 2004 U. ILL. L. REv. 829, 893-94 (noting the creation of servitudes based on use privileges in private development communities).

428. Restatement (Third) of Prop.: Servitudes $§ 2.6 \mathrm{cmt}$. d, illus. 2 (2000). 
problem with SEPs and the corresponding solution from adopting the law of servitudes can be described as follows:

As a condition of [including the patent owner's patent in the standard under development], the [standard-setting organization] requires [the owner of Patent $\mathrm{X}$ ] to execute an agreement limiting [licensing agreements to fair, reasonable, and nondiscriminatory terms]. The agreement states that the burden shall run with [Patent $\mathrm{X}]$ and the benefit shall be held by [implementers of the standard] in gross. The agreement creates a servitude burdening [the owner of Patent X]. The [SSO and implementers of the standard] hold[] the benefit in gross.

The possibility for servitudes to have an appurtenant benefit or a benefit held in gross also provides an opportunity for distinguishing between licenses and FRAND commitments. With a FRAND commitment, as discussed above, the benefit must be characterized as being held in gross. On the other hand, if a patent license also creates a servitude, we would characterize that servitude as having an appurtenant benefit. The consequence of this characterization may be that the party asserting his right to a benefit will more easily be able to prove the entitlement if the benefit is appurtenant instead of in gross.

Generally, FRAND commitments address the issue of the agreement being enforceable against successors in interest. ${ }^{429}$ However, these agreements generally do so under the theory that a FRAND commitment is governed solely by formal contract law, where consent to be bound will need to be obtained. ${ }^{430}$ If consent to be bound is not obtained, the assignor may have violated the agreement with the $\mathrm{SSO}$, but the assignee has committed no wrong and likely cannot be required to comply with the commitment. If FRAND commitments can be viewed as creating a property interest analogous to interests created under the law of servitudes, this could resolve one of the major problems that arises in the context of transferring SEPs.

\section{Servitudes and Other FRAND Problems}

Most of the problems relating to FRAND commitments can be resolved through contract language, with the exception of the transferability issue. Binding a successor in interest to an ordinary contract typically requires the successor's assent to be bound. ${ }^{431}$ On the other hand, viewing a FRAND commitment as creating a servitude resolves this issue by allowing the commitment to run with the patent.

429. Supra Part I.F.1.

430. The bylaws of IEEE-SA explicitly state that once a Letter of Assurance is accepted, there is an "encumbrance" that the patent owner must transfer with the patent. INST. OF ELEC. \& ElECS. ENG'RS STANDARDS Ass'N, supra note 73, at $\S 6$. However, this approach is still based on contract language and does not mean that a FRAND commitment is automatically considered to be an encumbrance on the SEPs of other SSOs.

431. See John Wiley \& Sons, Inc. v. Livingston, 376 U.S. 543, 550 (1964) (noting that "the principles of law governing ordinary contracts would not bind to a contract an unconsenting successor to a contracting party”). 
A servitude theory of FRAND commitments also has some application to the other problems that we have examined in this Article. A servitude by necessity, for example, may be created by implication when the absence of such a servitude would deprive one party "of rights necessary to reasonable enjoyment of the land. ${ }^{, 432}$ The idea of a servitude by necessity thus supports a view that if a FRAND commitment creates a servitude, the commitment should at least bind assignees when the assigned patent is an SEP. Because servitudes can also be created by express agreement, this supports the view that a FRAND commitment should bind an assignee when the SSO's IPR policy requires the commitment to cover essential noncore patents or commercially essential patents.

A servitude theory could also address the issue of whether nonmembers should be able to enforce a FRAND commitment. Like formal contract law and the idea of intended beneficiaries, some jurisdictions applying the law of servitudes would permit the benefit of a servitude to be created in a third party. ${ }^{433}$ Formal contract law, however, does not include the concept of a contract benefit held in gross. The idea of a "benefit in gross" assists not only in addressing the transfer issue but also in addressing the question of whether FRAND commitments are enforceable by nonmembers. If the benefit of a FRAND commitment is understood to be held in gross for standard implementers, it will not matter whether the implementer is a member of the SSO. Thus, a servitude approach could resolve the membernonmember issue. However, this will likely require the SSOs to not include limiting language that restricts the FRAND obligation to member licensees. Thus, just like the issue of attaching the servitude to noncore essential patents or commercially essential patents, the language of the SSO's IPR policy will govern.

A servitude theory, however, is less likely to be helpful with the issue of afteracquired patents. This is because our property theory relies on the idea that the servitude attaches at the time of the FRAND commitment. Thus, a contract theory analogizing to the law of secured transactions would likely still be necessary to address after-acquired patents.

\section{Invalidating Servitudes}

According to the current Restatement, servitudes are valid unless illegal, unconstitutional, or contrary to public policy. ${ }^{434}$ Under the Restatement, a servitude may be contrary to public policy if the servitude: (1) is arbitrary, spiteful, or capricious; (2) is unreasonably burdensome of a fundamental constitutional right; (3) unreasonably restrains alienability; (4) unreasonably restrains trade or competition; or (5) is unconscionable. ${ }^{435}$ A patent owner looking to invalidate a servitude created by a FRAND commitment may argue that the agreement imposes an unreasonable restraint on alienability, but we expect that this argument would fail. The applicable restriction on alienability is addressed in section 3.5 of the

432. Restatement (ThiRd) of Prop.: Servitudes $\S 2.15$ (2000).

433. Id. § 2.6(2); see also Willard v. First Church of Christ, Scientist, 498 P.2d 987 (Cal. 1972) (holding that when deeding real property to one person, a grantor may reserve an easement that benefits a third party).

434. Restatement (Third) OF Prop.: Servitudes $\S 3.1$ (2000).

435. Id. 
Restatement, which says that indirect restraints on alienation do not cause a servitude to be invalidated. ${ }^{436}$ Under the Restatement, an indirect restraint may include use limitations, reducing the realizable amount from transferring the property, or some other act that reduces the property's value. ${ }^{437}$ We would thus characterize the restriction on acceptable royalties imposed by a FRAND commitment as an indirect restraint on alienation that would not affect the servitude's validity.

On the other hand, requiring a PAE to be bound by a FRAND-RF agreement could arguably be contrary to public policy as a restraint on the trade of this entity if licensing patents is its primary source of income. Some of the litigation that arises in the FRAND and SEP transfer context involves patents that were obtained by PAEs with this sort of business model. ${ }^{438}$ In these situations, if the agreements with the SSO required FRAND-RF agreements, thus depriving the PAE of any income from the patent that they likely purchased as part of a patent portfolio, this total loss of value might amount to an unreasonable restraint on alienation or an unreasonable restraint on trade. However, a PAE that found itself subject to a servitude created by a FRAND commitment could still obtain some value from the patent in its possession, and thus the servitude would probably be valid.

\section{Adopting a Servitude Doctrine}

Servitudes in real property can be traced back to English common law and the seminal case of Tulk v. Moxhay ${ }^{439}$ Because servitudes were created by common law, legislative intervention would not be necessary to create a legally binding servitude approach to FRAND commitments. Such an approach could instead be adopted in case law by a court that recognizes the need for FRAND commitments to run with the patent. This would be consistent with how servitudes arose in property law.

In fact, there is some evidence that such a step would be a natural progression in terms of how courts currently view the transferability of FRAND commitments. Consider, for example, the 2008 ruling in Rembrandt v. Harris. ${ }^{40}$ The ruling is unpublished, and was later reversed for reasons unrelated to the court's initial conclusion on this point, but the Delaware court there stated, "[A]ccording to the clear and unambiguous terms of the 1995 patent statement issued by Rembrandt's predecessor, AT\&T, Rembrandt owes Harris a license to the ' 627 patent under RAND terms to the extent the patent is 'essential' to the implementation of the HDTV standard set by the Advanced Television System Committee." ${ }^{441}$ The "patent statement" in that case is what we have characterized as a FRAND

436. Id. § 3.5.

437. Id.

438. E.g., In re Innovatio IP Ventures, LLC, 921 F. Supp. 2d 903 (N.D. Ill. 2013) (concerning a PAE that initiated litigation against businesses that provided wireless service for their customers).

439. Supra text accompanying notes 400 and 401.

440. Rembrandt Tech. LP v. Harris Corp., 2008 WL 4824066 (Del. Super. Ct. Oct. 31, 2008), vacated, 2009 WL 2490873 (Aug. 14, 2009).

441. Id. at *1. 
commitment, and under the patent statement, AT\&T committed to granting nonexclusive licenses authorizing the use of essential patents in exchange for a reasonable royalty. ${ }^{442}$ AT\&T later assigned the patent to Rembrandt. ${ }^{443}$ The court noted that Rembrandt had notice of the patent statement and was thus bound by it to the extent that the patent in issue was essential. ${ }^{444}$ There, the court characterized Harris's right to a license as "a creature of contract," suggesting that the contract theory of FRAND commitments is what makes this patent statement binding on Rembrandt. ${ }^{445}$

But is calling it a "creature of contract" really a fair characterization of what is going on here? How often does contract law focus on notice when determining if a contract is enforceable against a nonparty? Certainly, as discussed above, there is plenty of support for the idea that a nonparty to a contract may be a third-party beneficiary who is entitled to enforce the contract in appropriate circumstances. ${ }^{446}$ But outside specific exceptions, like binding a principal to a contract that an agent entered into on the principal's behalf, ${ }^{447}$ a trustee's assumption of a contract during bankruptcy proceedings, ${ }^{448}$ and using principles of equitable estoppel to prevent a party from claiming the benefits of a contract while denying burdens under the same contract such as arbitration provisions, ${ }^{449}$ contract law typically relies on mutual assent in order to obligate a party to take on contractual burdens. ${ }^{450}$ So while the patent statement made by AT\&T was a contract, and Rembrandt had notice of the patent statement, this alone would likely not be enough to obligate Rembrandt to license the essential patents on FRAND terms - unless the contract is understood as creating an encumbrance that runs with the patent.

The court in Rembrandt explicitly relied on Rembrandt's having notice of the patent statement in concluding that Rembrandt was bound by the patent statement. ${ }^{451}$ This position is a direct echo of Tulk v. Moxhay, where the court asserted that "if an equity is attached to the property by the owner, no one purchasing with notice of that equity can stand in a different situation from the party from whom he purchased." ${ }^{, 452}$ In the language of Tulk v. Moxhay, the FRAND commitment is an instrument by which the patent owner attaches an "equity" to the

442. Id. at *2.

443. Id. at *1.

444. Id. at *3.

445. Id. at *5.

446. See supra Part II.B.3.

447. 12 Samuel Williston \& Richard A. Lord, A Treatise on the Law of CONTRACTS $\S 35: 34$ (4th ed. 2001).

448. 11 U.S.C. $\S 365$ (a) (2006) (permitting the trustee to "assume or reject any executory contract or unexpired lease of the debtor").

449. Int'1 Paper Co. v. Schwabedissen Maschinen \& Anlagen GMBH, 206 F.3d 411, 418 (4th Cir. 2000); WiLListon, supra note 447 §7:19.

450. See Hart, supra note 319, at 208 ("Mainstream modern contract law, as expressed in contract law hornbooks, focuses on the parties' intent to be bound to determine whether mutual assent has been manifested.").

451. Rembrandt Tech. LP v. Harris Corp., 2008 WL 4824066, at*3 (Del. Super. Ct. Oct. $31,2008)$.

452. (1848) 41 Eng. Rep. 1143, 1144. 
patent. ${ }^{453}$ Tulk v. Moxhay involved the creation of an entirely new legal doctrine for allowing encumbrances on real property to run with the land, and it is a seminal case that the majority of first-year property courses discuss. ${ }^{454}$ But when the Delaware court used very similar language, it was just a "creature of contract." We believe that the Rembrandt court felt constrained to use contract theory, so while the analysis tangentially alluded to a servitude theory of FRAND commitments, the court did not take the analysis one step further to explicitly recognize the FRAND commitment as creating a property interest.

Discussion of cases involving patent transfers thus hints at an undercurrent of servitude theory, and we argue that there should be formal recognition of the property theory that we advance for understanding the nature of the encumbrance created by the FRAND commitment. We urge that courts should explicitly recognize that the FRAND commitment attaches to the patent, and that the obligation to license on FRAND terms will run to subsequent assignees. Once courts explicitly recognize these commitments as attaching an encumbrance to the patent in a manner analogous to a servitude, the market will respond to the new legal certainty. Patent buyers will have an incentive to inquire into the existence of FRAND commitments as part of normal due diligence and will price the offer accordingly. For example, a patent encumbered by a FRAND commitment will likely bring in licensing income. To the purchaser, a FRAND-encumbered patent may be worth less than an unencumbered patent that is currently being licensed, but more than an unencumbered patent that is not currently being licensed. ${ }^{456}$

This new legal certainty is also desirable from a law and economics perspective. As Coleman notes in discussing the market paradigm, markets require contracting or exchange, and uncertainty threatens exchange. ${ }^{457}$ Coleman further observes that the appropriate application of law can reduce uncertainty and foster market cooperation. ${ }^{458} \mathrm{~A}$ clear definition of property rights and effective enforcement of contractual arrangements are two hallmarks of a robust economy. ${ }^{459}$ An understanding that FRAND commitments run with the patent creates an environment where investors are assured that these types of commitments will be enforced. Awareness of these carefully circumscribed property rights will then, as an ex ante matter, foster investment and support the adoption of the standardized technologies.

453. Id. at 1143 .

454. Id.

455. Rembrandt, $2008 \mathrm{WL} 4824066$, at $* 5$.

456. Estimates suggest that only a minority of existing patents are actually licensed, and approximately half of existing patents have been commercialized. Jason Rantanen, Lee Petherbridge \& Jay P. Kesan, Debate, America Invents, More or Less?, 160 U. PA. L. REV. PENNUMBRA 229, 242 (2012) (citing studies estimating that between 5\%-29\% of patents are licensed).

457. Jules L. Coleman, Risks And Wrongs 68 (1992).

458. Id. at 69 .

459. Paul G. Mahoney, The Common Law and Economic Growth: Hayek Might Be Right, 30 J. LEGAL STUD. 503, 523 (2001) (concluding that "the strong association between secure property and contract rights and growth is causal, and not simply a consequence of simultaneity"). 
Because of the nature of the FRAND commitment, courts should consider principles of both property and contract law when resolving disputes. The effects of the commitment should largely be determined by the language of the contract, and many of the problems noted in this Article could be resolved by a sufficiently detailed IPR policy. But if a patentee could extinguish the benefits of a FRAND commitment by transferring the patent to a third party, this would lead to inequitable results. Once FRAND commitments are formally recognized as creating an encumbrance on patents that "runs with the patent" to subsequent assignees, this will add legal certainty to situations where SEPs are assigned. Because the modern economy involves the frequent transfer of intellectual property, we expect that increased certainty concerning the availability of licenses after an assignment will strengthen competition and the standard-setting process.

However, this new legal certainty will need to be complemented by the certainty of license availability, which may be lacking if patent owners are permitted to seek injunctions for the infringement of SEPs. Thus, any efforts to improve legal certainty in the standards context must also consider the availability of injunctions as a remedy for patent infringement, a topic that we turn to next.

\section{FRAND COMMITMENTS, INJUNCTIONS, AND LIABILITY}

We now turn to the fifth problem in our hypothetical: May a patent owner seek an injunction against the use of an SEP by a standard adopter? This analysis is typically shaped by the presence of a FRAND commitment; specifically, the extent to which a FRAND commitment affects the possibility of an injunction.

The wide availability of injunctions, formerly a hallmark of patent law, has become more restricted over the last seven years since eBay v. MercExchange, when the Supreme Court enumerated a four-part test for determining if a permanent injunction is appropriate in cases involving patent infringement. ${ }^{460}$ The narrowing of the injunction standard is likely to be especially relevant when patent litigation concerns SEPs. In Apple, Inc. v. Motorola, Inc., Motorola sought an injunction against Apple for infringement of the '898 patent. ${ }^{461}$ Judge Posner, sitting by designation, concluded that by making the FRAND commitment, Motorola "implicitly acknowledged that a royalty is adequate compensation for a license to use that patent." ${ }^{, 462}$ The theoretical basis for this approach is examined in more detail in Part IV.B. below.

Before eBay v. MercExchange, injunctions were frequently sought and obtained when a patent was found to be infringed. ${ }^{463}$ The standard of the Federal Circuit

460. eBay Inc. v. MercExchange, LLC, 547 U.S. 388, 393 (2006).

461. 869 F. Supp. 2d 901, 913-14 (N.D. Ill. 2012).

462. Id. at 914 .

463. Dan L. Burk, Intellectual Property in the Cathedral, in ACCESS TO INFORMATION AND Knowledge: 21st Century Challenges in Intellectual Property and Knowledge GOVERNANCE 5 (Dana Beldiman ed., forthcoming 2013) (noting that before eBay, there was a presumption in the lower courts "in favor of an almost automatic permanent injunction for patent owners who proved their cases against infringers"), available at http://papers.ssrn.com/sol3/papers.cfm?abstract_id=2170093 (last modified Nov. 20, 2012). 
required defendants to establish that an injunction would be too harmful, ${ }^{464}$ rather than the current legal test where the plaintiff is required to establish that an injunction would not be too harmful. ${ }^{465}$ Injunction-seeking behavior was often motivated by the added leverage that an injunction gave its holder. ${ }^{466}$ For example, when NTP, Inc., a PAE, sued Research In Motion (RIM) for patent infringement, a jury initially awarded NTP $\$ 23$ million in damages in November $2002 .{ }^{467}$ The damages award was followed by an injunction, which was stayed pending appeal, and was then vacated by the Federal Circuit. ${ }^{468}$ In February 2006, the litigation was still ongoing. The district court judge, impatient with the parties' failure to negotiate, suggested that he was considering granting an injunction that would prohibit the U.S. sale of RIM's Blackberry line of products. ${ }^{469}$ Settlement negotiations quickly concluded, with RIM agreeing to pay NTP $\$ 612.5$ million in a full and final settlement with no provisions that might have required NTP to return the funds if the USPTO later invalidated the patents in issue. ${ }^{470}$ The threat of another injunction effectively turned a $\$ 23$ million jury verdict into a $\$ 612$ million payout.

\section{A. Injunctions After eBay v. MercExchange}

The patentee's right to exclude has long figured importantly in the issue of injunctions in patent litigation. ${ }^{471}$ In May 2006, the Supreme Court decided eBay v. MercExchange, replacing the Federal Circuit's injunction-friendly approach with a four-factor test for injunctions. ${ }^{472}$ Under $e$ Bay, a party seeking an injunction must show that irreparable injury has occurred, that money damages would be inadequate, that the balance of the hardships favors an equitable remedy, and that a

464. eBay, 547 U.S. at 391 (citing previous ruling in the Federal Circuit, MercExchange LLC v. eBay, Inc., 401 F.3d. 1323, 1339 (Fed. Cir. 2005), which applied that court's "general rule" that in cases of patent infringement, injunctions should issue "absent exceptional circumstances").

465. Id. at 393 .

466. Jaideep Venkatesan, Compulsory Licensing of Nonpracticing Patentees After eBay v. MercExchange, 14 VA. J. L. \& TECH. 26, 27-28 (2009) (“[I]njunction requests are often motivated by the leverage that they provide in subsequent licensing negotiations.").

467. NTP, Inc. v. Research In Motion, Ltd., 418 F.3d 1282, 1291 (Fed. Cir. 2005).

468. Id. at 1325 .

469. Tom Krazit, Judge Faces "Reality" in Blackberry Case, CNET News (Feb. 24, 2006, 4:27 PM), http://news.cnet.com/Judge-faces-reality-in-BlackBerry-case/2100-1041_3 -6043212 .html? (providing a transcript of the judge's remarks to the parties); see also Tom Krazit \& Anne Broache, BlackBerry Saved, CNET News (Mar. 3, 2006, 2:27 PM), http://news.cnet.com/BlackBerry-saved/2100-1047_3-6045880.html.

470. Krazit \& Broache, supra note 469.

471. See Menell, supra note 22, at 731 (noting arguments from the property rights movement "that exclusive patent rights meant that the patent owner should be free to decide who may use a claimed invention").

472. eBay Inc. v. MerExchange, LLC, 547 U.S. 388, 393-94 (2006). For criticism of the potentially sweeping effects of the eBay decision, see Mark P. Gergen, John M. Golden \& Henry E. Smith, The Supreme Court's Accidental Revolution? The Test for Permanent Injunctions, 112 COLUM. L. REV. 203 (2012). 
permanent injunction would not be harmful to the public interest. ${ }^{473}$ This has generally made it more difficult to obtain an injunction in patent litigation, with courts increasingly awarding ongoing royalties instead. ${ }^{474}$ Ongoing royalties are similar to compulsory licenses, except an ongoing royalty only applies to a particular set of defendants. ${ }^{475}$ Thus, a prevailing patentee might seek money damages for past infringement and ongoing royalties for future infringement but is less likely to successfully obtain an injunction post-eBay. ${ }^{476}$ According to research by Chien and Lemley, before $e B a y$, approximately $95 \%$ of requests for injunctions in patent cases were granted, but after $e B a y$, this number was down to about $75 \% .{ }^{477}$

In the context of standards, it is likely that the four factors of $e B a y$ will weigh against an injunction, especially when a FRAND commitment exists. ${ }^{478}$ When the Ninth Circuit decided an interlocutory appeal in Microsoft v. Motorola, the court noted in dicta that injunctive relief "is arguably a remedy inconsistent with the licensing commitment." ${ }^{, 479}$ While the Ninth Circuit did not state its position on this matter as a legal conclusion, its choice of wording did provide some hints as to the court's position. In addition to noting that an injunction was "arguably" inconsistent with a FRAND commitment, the Ninth Circuit also noted that "it could well be" that the only remedy that a patent owner could seek consistent with FRAND commitments made to ITU would be for the court to set a reasonable royalty rate and have it apply retrospectively. ${ }^{480}$ In Realtek $v$. LSI, the district court relied on Microsoft $v$. Motorola in granting a preliminary injunction against the enforcement of an ITC exclusion order. ${ }^{481}$ Thus, if a patent owner sues a standard adopter for infringement, trends in case law in the United States suggest that a court that finds infringement might limit remedies to reasonable royalties, reasoning that injunctions are an inappropriate means of redress when the patent in issue is an SEP. A court that does so and orders payment of past royalties at a reasonable rate,

473. eBay, 547 U.S. at 391.

474. E.g., Paice LLC v. Toyota Motor Corp., 609 F. Supp. 2d 620, 630 (E.D. Tex. 2009) (determining an ongoing royalty by applying the $25 \%$ Rule of Thumb, whereby the royalty is initially set at $25 \%$ of the profit margin on the product, and then reducing the amount accordingly in light of other factors, yielding a royalty of $1.5 \%$ of the value of the infringing part of the product).

475. Paice LLC v. Toyota Motor Corp., 504 F.3d 1293, 1313 n.13 (7th Cir. 2007) (distinguishing the equitable remedy of an ongoing royalty from the grant of a compulsory license).

476. See Chien \& Lemley, supra note 38, at 1 (noting that parties are generally unable to obtain injunctions in patent cases after $e$ Bay).

477. Id. at 9-10.

478. See Merges \& Kuhn, supra note 30, at 28-29.

479. Microsoft Corp. v. Motorola Inc., 696 F.3d 872, 885 (9th Cir. 2012).

480. Id. ("Whatever the appropriate method of determining the RAND licensing rate, it could well be that retrospective payment at the rate ultimately determined and a determination of the future rate, not an injunction banning sales while that rate is determined, is the only remedy consistent with the contractual commitment to license users of ITU standard-essential patents.").

481. Realtek Semiconductor Corp. v. LSI Corp., No. C-12-03451-RMW, 2013 WL 2181717, at *9 (N.D. Cal. May 20, 2013). 
to be determined by the court, would effectively be enforcing the FRAND commitment by refusing the patent owner the option of denying a license.

In his concurring opinion in $e B a y$, Justice Kennedy suggested that it might be inappropriate to grant injunctions "[w]hen the patented invention is but a small component of the product, ${ }^{, 482}$ a condition that will almost certainly be met in the context of standards that read on dozens of individual patents. However, Merges and Kuhn question whether merely making it more difficult to obtain an injunction provides sufficient protection for good faith adopters of open standards, suggesting that it would be beneficial to address the public interest factor relating to standards earlier in litigation than eBay permits. ${ }^{483}$ But addressing the issue earlier in litigation will only benefit good faith adopters of standards if there is not an alternative to Article III courts that still provides a viable possibility of injunctions. As we discuss in Part IV.C, the ITC offers just such an alternative.

Injunctions in the FRAND context are arguably very different from injunctions in typical patent litigation. Thus, we now turn to a theoretical analysis of the effect that FRAND commitments have on the entitlements held by the patent owner and prospective licensee.

\section{B. Property Rules and Liability Rules}

When the interests of two or more groups conflict, the government must generally decide which interest should be protected. As Calabresi and Melamed assert in their foundational article, entitlements may generally be protected by either property rules or liability rules. ${ }^{484}$ An injunction is an example of an entitlement protection under a property rule. ${ }^{485}$ In this framework, property rules are generally understood as conferring a right to exclude, whereas liability rules confer a right to be paid. ${ }^{486}$

By analogizing to criminal sanctions, Calabresi and Melamed suggest that applying property rules can deter actions that society views as harmful in a way that liability rules would not. ${ }^{487}$ If a thief is caught and a liability rule is applied to only require the thief to compensate the victim for the value of the stolen item, this would convert all property rules into liability rules ${ }^{488}$ in a regime where anyone could claim any property as long as he paid for it after the taking. Property rules may also be more efficient than liability rules when the lowest cost avoider is

482. eBay Inc. v. MercExchange, LLC, 547 U.S. 388, 396 (2006) (Kennedy, J., concurring).

483. Merges \& Kuhn, supra note 30 , at 48.

484. Guido Calabresi \& A. Douglas Melamed, Property Rules, Liability Rules, and Inalienability: One View of the Cathedral, 85 HARV. L. REV. 1089, 1092 (1972). Shapiro and Pearse list this article as the sixth most-cited law review article of all time. Shapiro \& Pearse, supra note 355 , at 1489 .

485. Robert P. Merges, Of Property Rules, Coase, and Intellectual Property, 94 Colum. L. REV. 2655, 2655 (1994) (referring to injunctions as being "the classic instance of a property rule").

486. Burk, supra note 463 , at 1.

487. Calabresi \& Melamed, supra note 484, at 1124-27.

488. Id. at 1124-25. 
known. ${ }^{489}$ If a potential thief knows that he wants a specific item, he can attempt to negotiate with the rightful owner instead of stealing it, because the potential thief is the lowest cost avoider. But if an item is damaged or destroyed in an accident, a liability rule to compensate the owner would be appropriate. In that case, a property rule would be inefficient, because that would require parties to negotiate value before an unforeseen accident. ${ }^{490}$

While the certainty of liability rules may be desirable in the case of patents, Calabresi and Melamed's analogy to criminal sanctions may be instructive. Though injunctions in patent cases may be harmful, it may be in the best interests of society to preserve injunctions in egregious cases of willful infringement. It may also be socially desirable to preserve the availability of injunctions in the standards context in very limited circumstances, such as when the implementer of the standard refuses anything less than a royalty-free licensing arrangement. ${ }^{491}$

Some argue that in the context of IP, property remedies like injunctions or exclusive rights may promote settlements and efficiency, ${ }^{492}$ though Menell warns that such remedies may also lead to inefficiencies and holdout under some circumstances. ${ }^{493}$ If Menell is correct, it follows that there are some situations where converting the property rule into a liability rule would be appropriate. Lee goes so far as to suggest that when an innovator improves on a patent, the situation should be analogized to accession in the property context, with ongoing royalties being favored over injunctions. ${ }^{494}$ However, Lee's approach may be too broad and thus remove the incentive for competitors to innovate around blocking patents. In our view, the standards context would likely fit Menell's characterization of circumstances where exclusivity may be undesirable. The potential harm to consumers in the form of increased prices and enforced injunctions persuades us to argue against injunctions as a general rule, especially in the context of standards. This conclusion is also supported by Reichman's reasoning in his widely cited article on liability rules in hybrid intellectual property systems, where Reichman urged that a liability rule would be more appropriate than an exclusionary property rule in the context of technical standards. ${ }^{495}$

At its core, the current discussion about injunctions demands that we determine how to allocate liability and entitlement. Burk's analysis of property and liability rules in the intellectual property context examines four possible allocative rules, ${ }^{496}$ which we summarize in the table below:

489. Id. at 1119 .

490. Id. at $1126-27$.

491. U.S. Dep't of Justice \& U.S. Patent \& Trademark Office, Policy Statement on Remedies for Standards-Essential Patents Subject to Voluntary F/RAND Commitments 6-7 (Jan. 8, 2013), available at http://www.justice.gov/atr/public/guidelines/290994.pdf.

492. See, e.g., Merges, supra note 485, at 2664 ("IPR cases fit the criteria set up by Calabresi and Melamed for application of a property rule ....").

493. Menell, supra note 22, at 730.

494. Peter Lee, The Accession Insight and Patent Infringement Remedies, $110 \mathrm{MiCH}$. L. REV. 175, 175 (2011).

495. J.H. Reichman, Legal Hybrids Between the Patent and Copyright Paradigms, 94 Colum. L. ReV. 2432, 2554-55 (1994).

496. Burk, supra note 463, at 2. 
Table 1. Possible Property Allocative Rules

\begin{tabular}{lll}
\hline & Property Rule & Liability Rule \\
\hline $\begin{array}{l}\text { Owner has } \\
\text { entitlement }\end{array}$ & Owner needs exclusivity. & Damages are adequate. \\
& Injunction against infringer. & $\begin{array}{l}\text { Infringer must pay owner } \\
\text { damages. }\end{array}$ \\
$\begin{array}{l}\text { Potential } \\
\text { infringer has } \\
\text { entitlement }\end{array}$ & $\begin{array}{l}\text { No infringement, or } \\
\text { infringer is prior user. }\end{array}$ & Reverse liability. \\
& $\begin{array}{l}\text { Non-owner may continue } \\
\text { use. }\end{array}$ & $\begin{array}{l}\text { Owner may pay damages to } \\
\text { non-owner, non-owner will } \\
\text { halt the use. }\end{array}$ \\
\hline
\end{tabular}

In some types of patent litigation, where the patent owner practices the patent and needs exclusivity, protection by a property rule in the form of an injunction may be appropriate. Injunctions arguably encourage innovation by requiring competitors to work around blocking patents, and therefore in some situations, the possibility of injunctions can benefit both patent owners and the market in general. However, in the standards context, we argue that a patent owner who has made a FRAND commitment has essentially stated that, as to their SEPs, damages will be adequate. This type of reasoning can also be found in multiple recent cases concerning FRAND commitments. ${ }^{497}$ Thus, by making the FRAND commitment, the SEP owner has waived a claim to using a property rule to preserve exclusivity. The FRAND commitment can thus be said to have converted the property rule into a liability rule, under which the patent owner would be entitled to money damages, but not an injunction, when the owner asserts his rights in the patent.

The lower right cell's "reverse liability" rule may be illustrated by property cases about moving to the nuisance, especially as depicted in Spur Industries, Inc. v. Del E. Webb Development Co. ${ }^{498}$ In such a case, the party that causes the nuisance is entitled to payment from the injured party for the cost of abating the nuisance. ${ }^{499}$ Burk suggests that a reverse liability approach could potentially apply in the standards context if a court focused on a breach of the FRAND commitment as the injury instead of focusing on patent infringement. ${ }^{500}$ If a court found both that a FRAND commitment was breached and a patent was infringed, then instead of requiring the infringer to pay ongoing royalties, the court might choose to require the patent owner to compensate the infringer for the cost of adopting a noninfringing alternative. In normal patent infringement cases, we do not think this option would be appropriate, since it requires the patent owner to pay for the right to exclude after having already paid to develop the technology and obtain the

497. Microsoft Corp. v. Motorola, Inc., 696 F.3d 872, 885 (9th Cir. 2012); Apple, Inc. v. Motorola, Inc., 869 F. Supp. 2d 901, 914 (N.D. Ill. 2012).

498. 494 P.2d 700 (Ariz. 1972) (applying the "coming to a nuisance" doctrine).

499. Burk, supra note 463 , at 5.

500. Id. at 7 . 
patent. However, Burk suggests that a reverse liability rule may provide a deterrent effect for abusive use of an SEP in the case of standards. ${ }^{501}$

While it may sound good in theory, a reverse liability rule would likely not work in practice, even in the context of standards. If the patent owner were required to pay the infringer for the cost of designing around the patent, this would be very impracticable on several levels. First, such a design around may not even be feasible. Second, such a payment may effectively amount to the SEP owner paying off a competitor to exit the market for the standardized good, which may raise antitrust concerns. Third, the payment is likely to be so high that no reasonable SEP owner would be interested. Thus, a reverse liability theory would likely not have any lasting impact in the context of SEPs, and the effect of a FRAND commitment would be limited to converting the property rule into a liability rule.

Even if FRAND commitments are understood as converting a property rule favoring injunctions into a liability rule where only damages may be sought, this conversion would likely only occur in traditional court settings. We turn now to the existence of different kind of injunction that remains available to patent holdersthe exclusion order.

\section{ITC Exclusion Orders}

In eBay, the Supreme Court overruled the Federal Circuit's "general rule" that permanent injunctions should issue in patent cases unless there were "unusual circumstances" such that denial of an injunction was necessary to protect the public interest. ${ }^{502}$ However, this general rule still survives elsewhere in patent-related litigation: the ITC. The ITC is not discussed as often in patent literature as litigation before Article III courts, but Chien and Lemley provide a detailed analysis of patent disputes before the ITC in their 2012 article. ${ }^{503}$

The ITC allows patent owners to seek exclusion orders under section 1337 of title 19. ${ }^{504}$ According to the Federal Circuit, as a non-Article III court, the ITC is not bound by the equitable test of eBay. ${ }^{505}$ Under section 1337, if the ITC determines that the section has been violated, the articles concerned shall "be excluded from entry into the United States," unless an exception applies. ${ }^{506}$ Thus, the burden is inverted. In Article III courts, eBay puts the burden on the patentee to establish that an injunction would not violate the four factors, ${ }^{507}$ whereas in cases before the ITC, the infringer carries the burden of establishing that an exclusion order would be too harmful. ${ }^{508}$

The ITC's standard resembles the pre-eBay standard of the Federal Circuit, which required a showing of exceptional circumstances to support not granting an

501. See id.

502. eBay Inc. v. MercExchange, LLC, 547 U.S. 388, 393-94 (2006).

503. Chien \& Lemley, supra note 38.

504. 19 U.S.C. $\S 1337$ (2006).

505. Spansion, Inc. v. Int'1 Trade Comm'n, 629 F.3d 1331, 1359 (Fed. Cir. 2010).

506. 19 U.S.C. $§ 1337(d)(2006)$.

507. eBay, 547 U.S. at 393.

508. See Spansion, Inc., 629 F.3d at 1358 (listing the statutory factors for not granting an exclusion order). 
injunction. ${ }^{509}$ Adequacy of money damages is not considered by the ITC, likely in part because the ITC cannot award damages. ${ }^{510}$ The presence of irreparable injury and the balance of the hardships between the patent owner and the infringer are also not factors before the ITC, which instead focuses on several categories of harm that we would characterize as public interest harms: (1) public health and welfare; (2) competitive conditions across the whole U.S. economy; (3) the existence of competitive articles produced in the United States; and (4) the effect on U.S. consumers. ${ }^{511}$ However, the ITC has only rarely found that public interest factors weigh against an exclusion order, and in these cases, the products in issue were necessary for a purpose related to health and welfare, and there was no other supplier who could meet the demand in a reasonable time period. ${ }^{512}$ Chien and Lemley found that in the ITC relatively little emphasis has been placed on competitive conditions or harm to consumers as factors that might weigh against an exclusion order. ${ }^{513}$ Thus, while the presence of patents in standards might weigh against granting an exclusion order, the ITC's current lack of emphasis on these two factors may make it more difficult to avoid an exclusion order, even in the standards context. ${ }^{514}$

Thus, while eBay seemingly offers some protection against injunctions for adopters of a standard when the litigation is in an Article III court, the ITC continues to grant exclusion orders as its sole statutorily authorized method of indicating that a patent owner's exclusive rights have been violated. ${ }^{515}$ The ITC's approach to patents in the standards context should be revised. We are in favor of the approach promoted by the DOJ and USPTO in a letter to the ITC dated January 8,2013 , wherein the two agencies make a joint recommendation that exclusion orders should not be granted in the case of SEPs unless the putative licensee has refused to pay any royalties. ${ }^{516}$

An alternative solution is for Article III courts to grant injunctions against the enforcement of exclusion orders entered due to the alleged infringement of SEPs. This approach was recently taken by Judge Whyte in the Northern District of California in Realtek Semiconductor Corp. v. LSI Corp. ${ }^{517}$ In Realtek, Judge Whyte relied on Microsoft v. Motorola to conclude that LSI's failure to offer a license on FRAND terms prior to seeking an exclusion order from the ITC violated LSI's

509. eBay, 547 U.S. at 391 (citing previous ruling in the Federal Circuit, MercExchange LLC v. eBay, Inc., 401 F.3d. 1323, 1339 (Fed. Cir. 2005), which applied that court's "general rule" that in cases of patent infringement, injunctions should issue "absent exceptional circumstances").

510. Chien \& Lemley, supra note 38 , at 14.

511. 19 U.S.C. $§ 1337(d)$ (2006); Spansion, Inc., 629 F.3d at 1358.

512. Chien \& Lemley, supra note 38 , at 19-20.

513. Id. at 25 .

514. See id. at 41 (expressing the authors' opinion that the ITC should not grant injunctions for SEPs).

515. Spansion, Inc., 629 F.3d at 1358 (noting the "legislative determination that an injunction is the only available remedy for violations of Section 337").

516. U.S. Dep't of Justice \& U.S. Patent \& Trademark Office, supra note 491, at 6-7.

517. No. C-12-03451-RMW, 2013 WL 2181717 (N.D. Cal. May 20, 2013). 
obligations to IEEE pursuant to its FRAND commitments. ${ }^{518}$ Accordingly, Judge Whyte granted Realtek's request for a preliminary injunction against enforcement of the ITC exclusion order, pending resolution of a trial to determine the proper FRAND royalty rate. ${ }^{519}$

The structure of section 1337 also permits the President to disapprove an exclusion order within sixty days of issuance. ${ }^{520}$ The use of this power is very rare, but in August 2013, the Obama administration disapproved an ITC exclusion order that would have permitted Samsung to keep several Apple devices from being imported into the United States. ${ }^{521}$ In the letter, U.S. Trade Representative Michael Froman emphasized that public policy considerations weighed against an exclusion order in this instance, where the infringed patents in issue were SEPs that were subject to FRAND commitments. ${ }^{522}$

In our view, neither injunctions nor exclusion orders should be available to patentees bound by a FRAND commitment unless extreme circumstances exist. For example, if the adopter refuses to pay royalties at any price, this type of behavior may justify an injunction. Beyond that sort of narrow circumstance, however, the FRAND commitment should be understood as converting the property rule into a liability rule, since by making the commitment, the patentee has freely acknowledged that royalties would provide adequate compensation for the loss of exclusivity. We argue that a general prohibition on injunctive relief when a FRAND commitment exists would be consistent with well-established approaches to property and liability rules, and is a logical progression following the Supreme Court's recent narrowing of injunction policy in patent litigation.

\section{CONCLUSION}

Information is like currency. Some sources indicate that over $50 \%$ of the business output of industry in the United States is comprised of intangible assets, many of which are protected by intellectual property rights. ${ }^{523}$ Companies are often bought and sold based on the value of their IP portfolios, especially patents. ${ }^{524}$ These patent transfers have significant implications for technology-reliant industries like ICT industries. These industries often utilize standards to facilitate interoperability, with SSOs often requiring owners of essential patents to commit to licensing these patents on FRAND terms to future licensees.

518. Id. at *6.

519. Id. at *9.

520. 19 U.S.C. $§ 1337(j)(2006)$.

521. Letter from Michael B. G. Froman, U.S. Trade Rep., to Hon. Irving A. Williamson, Chairman, U.S. Int'l Trade Comm'n. (August 3, 2013), available at http://www.ustr.gov /sites/default/files/08032013\%20Letter_1.PDF.

522. Id.

523. Request for Comments on Eliciting More Complete Patent Assignment Information, 76 Fed. Reg. 72372 (Nov. 23, 2011).

524. See Ron Corbett, IP Strategies for Start-up eCommerce Companies in the Post-DotBomb Era, 8 TEX. WESLEYAN L. REV. 643, 649 (2002) (“A strong patent portfolio may signal an attractive buy-out opportunity by entities prospecting for high-technology companies that are considered to be undervalued because of their unused or unrealized IP assets."). 
Numerous court decisions demonstrate the types of problems regarding FRAND commitments that we have delineated in this Article. But despite these problems, the theoretical foundations that might help us understand the nature and scope of the FRAND commitment have not been studied. In this Article, we examined these theoretical foundations and exposed the limitations of theories grounded in patent, antitrust, and contract in terms of enabling the analysis of issues and problems concerning the FRAND commitment. We noted that a contract-based theory offers a good approach in many situations, but we also exposed the significant limitations of contract theory as applied to FRAND commitments. In particular, contract theory fails to effectively address the problem of enforcing FRAND commitments after an SEP has been transferred.

In this Article, we posited for the first time that understanding a FRAND commitment through the lens of property would be an effective approach to support the public interest in favor of having a FRAND commitment run with the patent. We also concluded that such an approach would be consistent with U.S. law concerning servitudes, and that this theoretical approach could resolve one of the major problems that arises when SEPs are transferred. By applying the classic theories of Hohfeld and those of modern scholars like Merrill and Smith, we established that a FRAND commitment creates a hybrid type of right that cannot be understood purely through the lens of contract law. This approach then allowed us to conceptualize the FRAND commitment as an encumbrance that runs with the patent, similar to a servitude under real property law.

Finally, we examined the use of injunctions in patent litigation, and in FRAND disputes in particular, and discussed the availability of injunctions in nontraditional forums like the ITC. Through application of theoretical insights concerning property rules and liability rules, we established why a FRAND commitment should be understood as a waiver of the right to seek an injunction for infringement of an SEP. By applying the FRAND commitment theories espoused in this Article to prohibit injunctions for infringement of SEPs and to protect the transferability of FRAND commitments, courts and SSOs can ensure the continued viability of a competitive marketplace for ideas and innovation. 
APPENDIX

GLOSSARY

\begin{tabular}{ll}
\hline Acronym & Meaning \\
\hline ATSC & Advanced Television Systems Committee \\
AVS & China's Audio and Video Coding Standard Workgroup \\
DOJ & Department of Justice \\
EC & European Commission \\
ETSI & European Telecommunications Standards Institute \\
EULA & End User Licensing Agreement \\
FTC & Federal Trade Commission \\
FRAND & Fair, Reasonable, and Nondiscriminatory \\
FRAND-RF & Fair, Reasonable, and Nondiscriminatory - Royalty-free \\
HDTV & High-definition television \\
ICT & Internet, Computing, and Telecommunications \\
& Institute of Electrical and Electronics Engineers - Standard \\
IEEE-SA & Association \\
IP & Intellectual Property \\
IPO & Intellectual Property Owners Association \\
IPR & Intellectual Property Rights \\
ITC & International Trade Commission \\
ITU & International Telecommunications Union \\
MDL & Multi-district litigation \\
PAE & Patent Assertion Entity \\
RFC & Request for Comments \\
SEPs & Standard Essential Patents \\
SSOs & Standard-Setting Organizations \\
UCC & Uniform Commercial Code \\
USPTO & United States Patent and Trademark Office \\
VITA & VMEbus International Trade Association \\
\hline &
\end{tabular}

